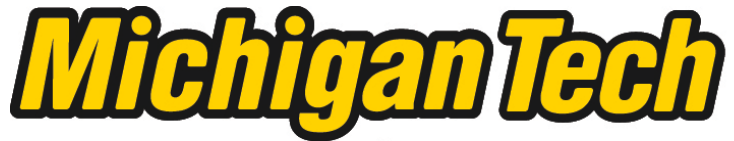 \\ Michigan Technological University Create the Future Digital Commons @ Michigan Tech
}

Dissertations, Master's Theses and Master's Reports - Open

Dissertations, Master's Theses and Master's

Reports

2011

\section{Assessing drinking water quality at source and point-of-use : a case study of Koila Bamana, Mali, West Africa}

Mathew D. Seib

Michigan Technological University

Follow this and additional works at: https://digitalcommons.mtu.edu/etds

Part of the Civil and Environmental Engineering Commons

Copyright 2011 Mathew D. Seib

\section{Recommended Citation}

Seib, Mathew D., "Assessing drinking water quality at source and point-of-use : a case study of Koila Bamana, Mali, West Africa ", Master's report, Michigan Technological University, 2011.

https://doi.org/10.37099/mtu.dc.etds/498

Follow this and additional works at: https://digitalcommons.mtu.edu/etds

3 Part of the Civil and Environmental Engineering Commons 


\title{
ASSESSING DRINKING WATER QUALITY AT SOURCE AND POINT-OF-USE: A CASE STUDY OF KOILA BAMANA, MALI, WEST AFRICA
}

\author{
By \\ Mathew D. Seib
}

\begin{abstract}
A REPORT
Submitted in partial fulfillment of the requirements for the degree of MASTER OF SCIENCE

(Environmental Engineering)
\end{abstract}

MICHIGAN TECHNOLOGICAL UNIVERSITY

2011

(C) 2011 Matthew D. Seib 
This report, "Assessing Drinking Water Quality at Source and Point-of-Use: A Case Study of Koila Bamana, Mali, West Africa," is hereby approved in partial fulfillment of the requirements for the Degree of MASTER OF SCIENCE IN ENVIRONMENTAL ENGINEERING.

Civil and Environmental Engineering

Signatures:

Report Advisor:

Dr. Kurtis Paterson

Department Chair:

Dr. David Hand

Date: 


\section{TABLE OF CONTENTS}

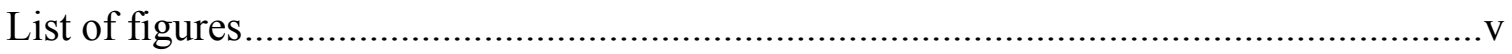

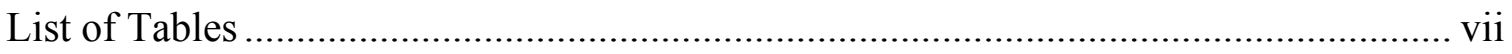

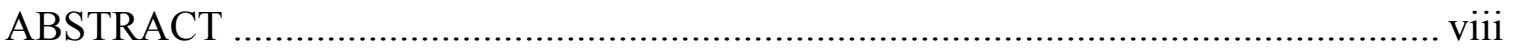

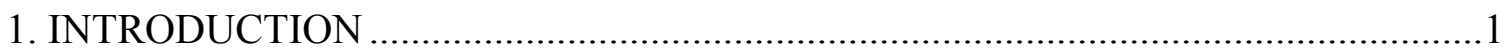

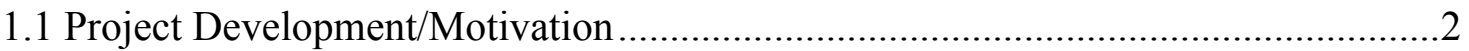

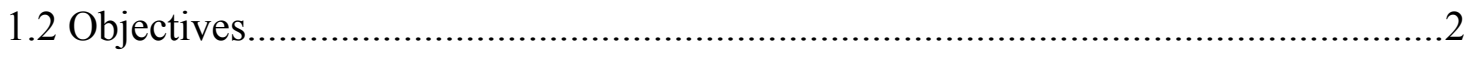

2. BACKGROUND/SITE CHARACTERIZATION .....................................................

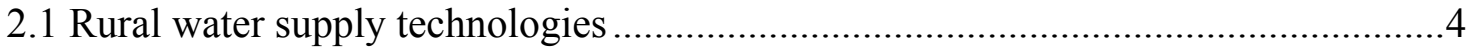

2.1.1 India/Mali Mark II Hand Pump................................................................. 4

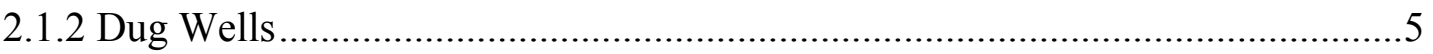

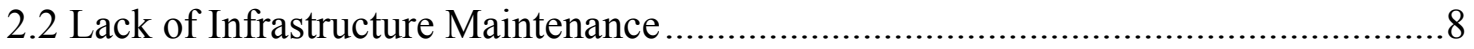

2.3 Poor Water Quality Strategies.......................................................................

2.4 Common Behaviors, Beliefs, and Understanding .......................................... 10

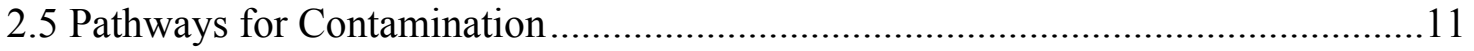

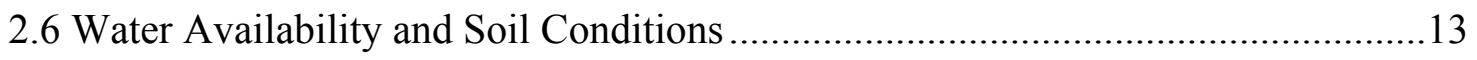

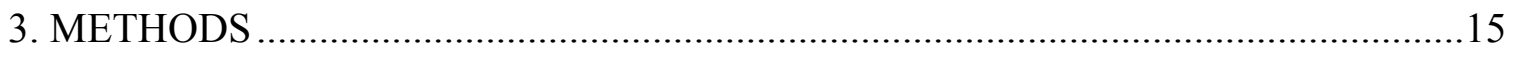

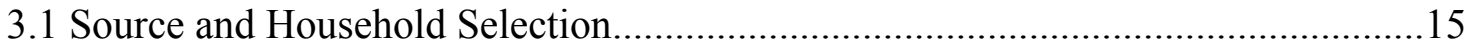

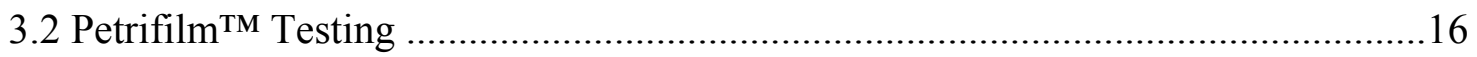

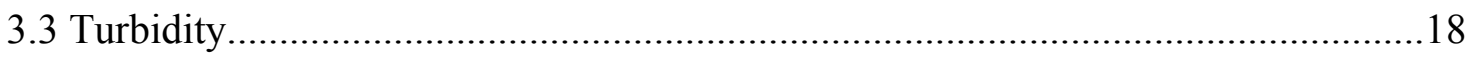

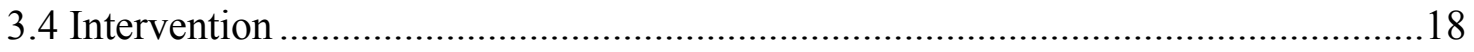

3.5 Water Retrieval and Water Level Monitoring ................................................19

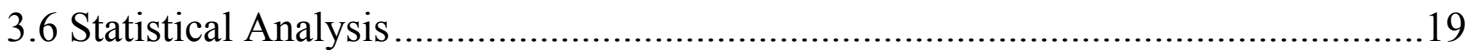

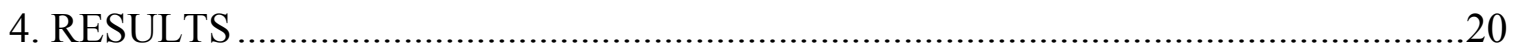

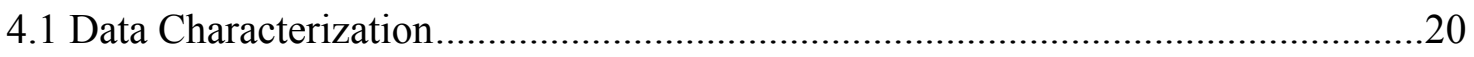

4.2 Bacterial Testing Results at Sources ..................................................................23

4.3 Bacterial Testing Results at Point-of-Use ...........................................................25

4.3.1 Point-of-Use Variability Based on Source ....................................................27

4.3.2 Point-of-Use Variability Based on Season ....................................................28

4.4 Bacterial Soil Testing Results at Dug Wells .......................................................29 


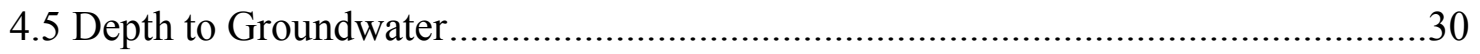

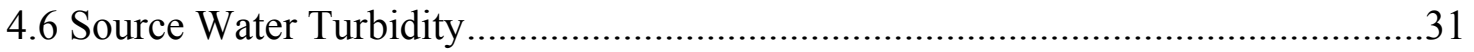

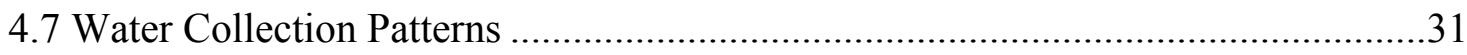

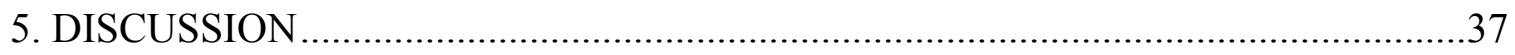

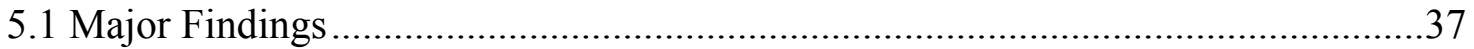

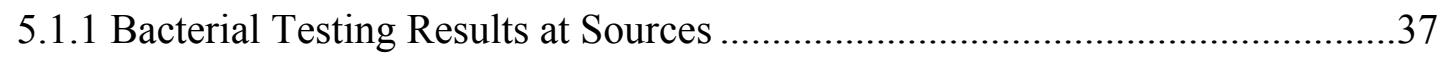

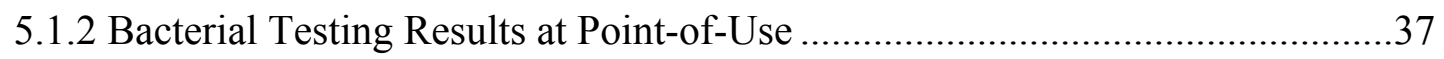

5.1.3 Bacterial Soil Testing Results at Dug Wells ................................................39

5.1.4 Relationship of Turbidity with Groundwater Depth, Season, and Microbes ....39

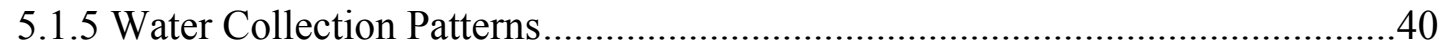

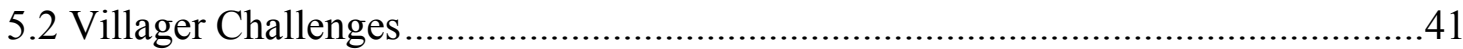

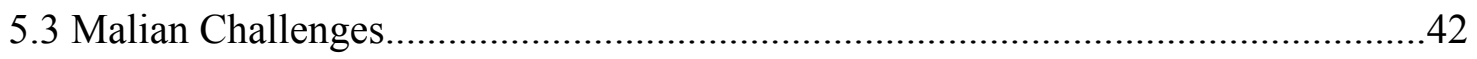

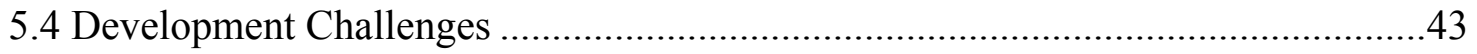

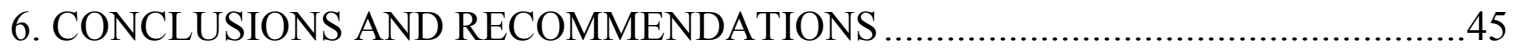

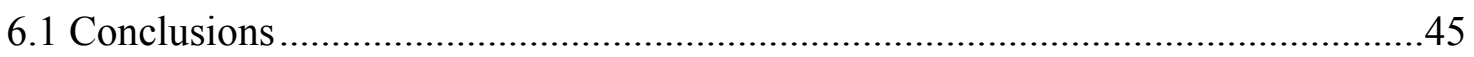

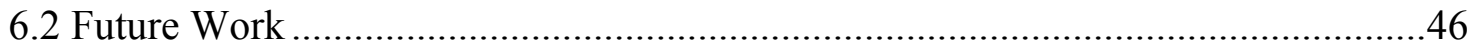

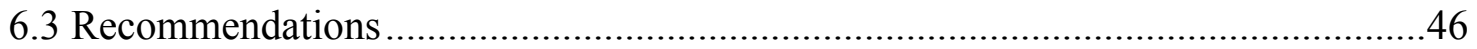

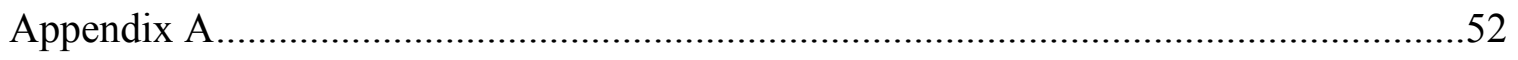

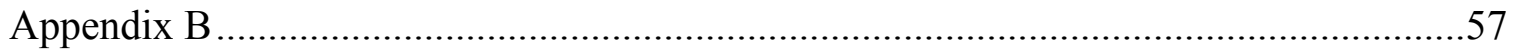

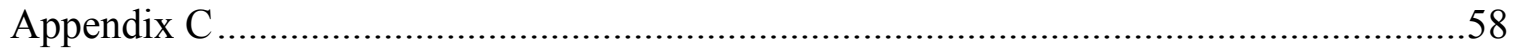

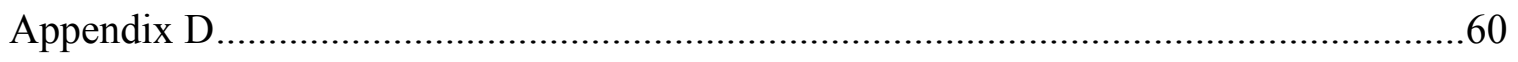

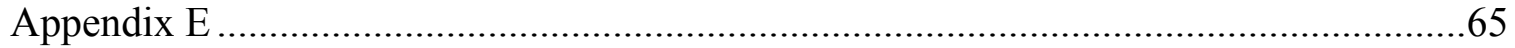




\section{LIST OF FIGURES}

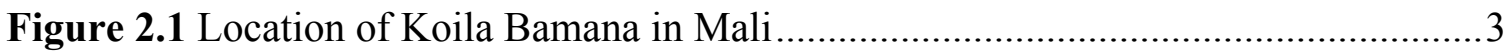

Figure 2.2 Diagram of the India Mark II hand pump ……............................................

Figure 2.3 Diagrams of typical fully lined and partially lined dug well...........................6

Figure 2.4 Woman using well bag to draw water from a partially lined dug well .............7

Figure 2.5 List of improved and unimproved drinking water sources according to the Joint Monitoring Programme ......................................................................

Figure 2.6 Koila Bamana average monthly maximum and minimum temperatures, average monthly rainfall days, and seasons

Figure 2.7 Location of Koila Bamana relative to Niger River, irrigated rice fields, and the major canal network for the area

Figure 3.1 Water samples collected from sources ( $\mathrm{W}=$ dug well, $\mathrm{P}=$ hand pump) plus households (circular and triangular markers) during this study...............16

Figure 3.2 $3 \mathrm{M}^{\mathrm{TM}}$ Petrifilm ${ }^{\mathrm{TM}}$ count plates showing no bacterial contamination (left) and both total coliform and E.coli bacterial contamination (right).

Figure 4.1 Normalized total coliform variability across sampling range using water samples evaluated in triplicate.

Figure 4.2 Normalized E.coli variability across sampling range using water samples evaluated in triplicate.

Figure 4.3 Total coliform frequency distribution for all samples in study .....................22

Figure 4.4 E.coli frequency distribution for all samples in study .................................23

Figure 4.5 Seasonal change in depth to water table for hand pumps (P) and dug wells

(W) in Koila Bamana, Mali.

Figure 4.6 Seasonal change in turbidity by source for water from hand pumps (P) and dug wells (W) in Koila Bamana, Mali.

Figure 4.7 Percent of households relative to early rainy season that switched from using a dug well to a hand pump during subsequent seasons in Koila Bamana, Mali

Figure 4.8 Summary of water household collection habits over entire testing period, as assessed seasonally

Figure 4.9 Early rainy season (Season \#1) water collection points relative to household locations

Figure 4.10 Late rainy season (Season \#2) water collection points relative to household locations

Figure 4.11 Cold season (Season \#3) water collection points relative to household locations......

Figure 4.12 Hot season (Season \#4) water collection points relative to household locations...

Figure 5.1 Intervention flow chart 
Figure 5.2 Historical effectiveness of various interventions to prevent diarrhea ............45 


\section{LIST OF TABLES}

Table 2.1 List of contamination pathways and concerns identified for water source types (dug well, hand pump) in Koila Bamana, Mali.................................. 12

Table 4.1 General data summary for total coliform in water samples..........................20

Table 4.2 Total coliform characterization across data range ........................................22

Table 4.3 E.coli characterization across data range .................................................22

Table 4.4 Seasonal total coliform (CFU/mL) at hand pump (P) or dug well (W) water sources

Table 4.5 Seasonal E.coli (CFU/mL) at hand pump (P) or dug well (W) water sources..24

Table 4.6 Incidence rates (\% of samples) for total coliform in hand pump water samples at source and household

Table 4.7 Incidence rates ( $\%$ of samples) for total coliform in dug well water samples at source and household

Table 4.8 Incidence rates (\% of samples) for E. Coli in hand pump water samples at source and household

Table 4.9 Incidence rates (\% of samples) for E. Coli in dug well water samples at source and household

Table 4.10 Total coliform (CFU/mL) averages at households, comparing effect of inclusion or exclusion of values $>150$

Table 4.11 E. Coli (CFU/mL) averages at households, comparing effect of inclusion or exclusion of values associated with total colony counts $>150$

Table 4.12 Point-of-use comparison for change in seasonal microbial contamination based on source used

Table 4.13 Point-of-use comparison for change in seasonal microbial contamination based on source used

Table 4.14 Point-of-use comparison for change in microbial contamination based on source for individual seasons.

Table 4.15 Point-of-use comparison for change in microbial contamination based on source for individual seasons.

Table 4.16 Characterization of soil bacterial content next to mouth of dug wells

Table 4.17 Summary of individual household water collection habits.

Table 5.1 Microbial contamination $(\mathrm{CFU} / \mathrm{mL})$ comparison of water sources in Koila Bamana, Mali for 2010-2011 (annual averages)

Table 5.2 Microbial contamination $(\mathrm{CFU} / \mathrm{mL})$ comparison of water at source and point-of-use in Koila Bamana, Mali for 2010-2011 (annual averages) 


\section{ABSTRACT}

Ensuring water is safe at source and point-of-use is important in areas of the world where drinking water is collected from communal supplies. This report describes a study in rural Mali to determine the appropriateness of assumptions common among development organizations that drinking water will remain safe at point-of-use if collected from a safe (improved) source. Water was collected from ten sources (borehole wells with hand pumps, and hand-dug wells) and forty-five households using water from each source type. Water quality was evaluated seasonally (quarterly) for levels of total coliform, E.coli, and turbidity. Microbial testing was done using the $3 \mathrm{M}$ Petrifilm ${ }^{\mathrm{TM}}$ method. Turbidity testing was done using a turbidity tube. Microbial testing results were analyzed using statistical tests including Kruskal-Wallis, Mann Whitney, and analysis of variance. Results show that water from hand pumps did not contain total coliform or E.coli and had turbidity under 5 NTUs, whereas water from dug wells had high levels of bacteria and turbidity. However water at point-of-use (household) from hand pumps showed microbial contamination - at times being indistinguishable from households using dug wells indicating a decline in water quality from source to point-of-use. Chemical treatment at point-of-use is suggested as an appropriate solution to eliminating any post-source contamination. Additionally, it is recommended that future work be done to modify existing water development strategies to consider water quality at point-of-use. 


\section{INTRODUCTION}

Water is essential for life. In many places fresh water is scarce, which has a direct impact on the quality of life for people in those areas. For health reasons, it is important that only water free of pathogens and toxic chemicals - good quality and safe water - be used for human consumption. Unfortunately, many of the places where waterborne illnesses are prevalent are poor countries that are unable to satisfy the water needs of their citizens. For decades development organizations and governments have been working to solve these types of water problems.

In 2000, the United Nations (UN) created a large, collaborative effort known as the Millennium Development Goals (MDGs). The Goals were developed as a means to challenge all countries to drastically reduce many of the problems that plague the world's poor. One of these goals is specifically related to water which aims to "reduce by half the proportion of people without sustainable access to safe drinking water" (UN 2010). The basic concepts of to this goal are straightforward, focusing on water access and quality. Access to water needs to be sustainable to ensure availability in areas where water is scarce and existing sources are unreliable. Additionally, water needs to be safe - meaning free of pathogens and harmful chemicals - so there are no human health risks.

To date, the water goal has relied on the assumption that water will remain safe from the time it leaves the tap to when it is consumed (Carter, et al. 1999). This assumption is made evident in the way the UN monitors progress towards its water goal. The UN's main indicator for progress is the "proportion of population with sustainable access to an improved water source" (UNESCO 2011). There is no mention of also seeking to ensure water is safe at the time of consumption.

This lack of a stated need to ensure pathogen-free water at the point-of-consumption is surprising given how the water goal is typically implemented. In developing areas of the world the water goal is put into practice by installing public access points (taps) because of the high cost associated with providing private taps to individual households. Water from these sources is often safe coming out of the tap, but is frequently contaminated by consumption. The risk of contamination is inherent in the need to collect and store water from a public tap (Trevett, et al. 2004; Wright, et al. 2004; Gundry, et al. 2004; Clasen and Bastable 2003; Sobsey, et al. 2003; Jensen, et al. 2002).

Not surprisingly, the common theme for water development in recent decades has been on installing improved water sources. However, little, if any, follow-up monitoring is done once the new source is installed to ensure it is functioning. Additionally, water 
quality monitoring is rarely being done at point-of-use to determine if the selected solution acts as an appropriate strategy for improving quality of life.

In recent years the attitude of development organizations has begun to change regarding how progress towards meeting the water goal is measured. The WHO/UNICEF Joint Monitoring Programme (JMP), which is charged with monitoring progress, now recognizes the need to monitor water quality at points-of-consumption. However, a major obstacle to doing so is the current lack of an accepted, cost-effective means to conduct water quality testing on a global scale. The WHO and UNICEF are currently conducting pilot programs in several countries, but have yet to establish a standard means of monitoring water quality (JMP 2010).

\subsection{Project Development/Motivation}

The motivation for evaluating drinking water quality at source and point-of-use came from my experience working as a Peace Corps Volunteer in the village of Koila Bamana, Mali. During my service I became aware of several factors in the community that were likely resulting in water contamination at sources or during collection and storage (pointof-use). These factors called into question the basic assumption that water will remain safe from the time it leaves the tap to when it is consumed. If this assumption was shown to be faulty, it would have implications for future development strategies focused on water quality.

\subsection{Objectives}

The general objective of this project was to determine if promoting interventions at the source (improved vs. unimproved source) is a good way to ensure good water quality, or if other strategies might be needed to ensure safe water is being consumed at point-ofuse. To resolve this, the following specific objectives were investigated to determine:

1) If there is a difference in water quality between different source technologies in village (hand pumps and hand-dug wells),

2) If there is water quality degradation at point of consumption (point-of-use) compared to each improved water source observed,

3) If drinking water quality at point-of-use varies based on source used, and

4) If drinking water quality at point-of-use varies based on season. 


\section{BACKGROUND/SITE CHARACTERIZATION}

When I entered into Peace Corps service I was placed in the village of Koila Bamana (Dioro Cerlce) in the Segou region of Mali in West Africa (Figure 2.1). The village is composed of roughly 250 family compounds with a total population of about 2,500. The majority of the adult population is illiterate and has completed only a few years of primary education. Most people are farmers relying on millet as the primary food source and rice as a cash crop. Rice is cultivated in large irrigated fields that receive flood water through a series of canals fed by the Niger River $7 \mathrm{~km}$ away.

Koila Bamana is fairly isolated. The nearest electricity grid of any kind (Dioro) is about $15 \mathrm{~km}$ away and the nearest community with a centralized water system is $80 \mathrm{~km}$ away (Segou). This means any water development projects need to rely on off-grid or human powered systems and cannot simply be achieved by constructing a pipeline to a nearby community.

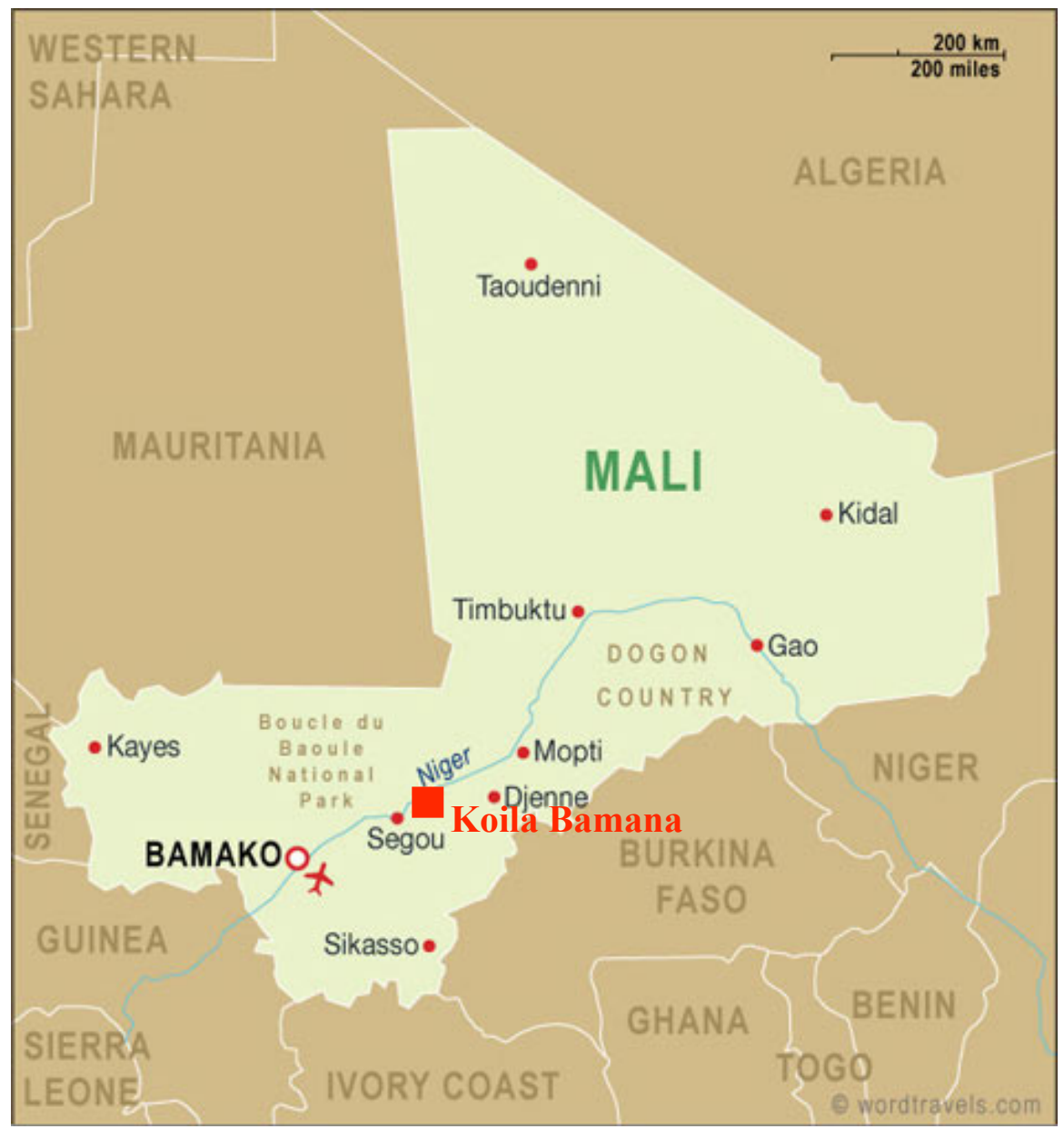

Figure 2.1 Location of Koila Bamana in Mali, adapted from Wordtravels (2011) 


\subsection{Rural water supply technologies}

There are several types of water supply technologies used in rural Mali for drinking water. These include: dug wells, boreholes fitted with hand pumps or foot pumps, and centralized systems with a water tower and public taps. The only two types present in Koila Bamana are dug wells and boreholes with India/Mali Mark II hand pumps.

\subsubsection{India/Mali Mark II Hand Pump}

The India Mark II hand pump (Figure 2.2) was initially developed in India to provide clean drinking water to poor, rural populations. It has now been introduced to many developing countries, making it the most widely used hand pump in the world (Colin 1999). The India/Mali Mark II hand pump is essentially the same design, but the pump was intended to be manufactured in Mali, so some of the fabrication materials are different from the India Mark II (Reynolds 1992).

The India/Mali Mark II is a piston pump that is installed inside a lined borehole. The pump has a modular design allowing it to access water at depths up to 50 meters. The hand pump is anchored into a concrete apron around the top of the borehole to prevent surface contaminants from entering the borehole or quickly seeping into the water table by taking a path of least resistance that may exist along the borehole lining (UNICEF 1993). There are six India/Mali Mark II hand pumps in Koila Bamana - four of which are used for household drinking water. The other two are not typically used for households because they are not within reasonable walking distances from most homes.

The India/Mali Mark II hand pump has played a major role in water supply for Mali in the past several decades. Mali experienced a period of significant drought in the 1970s. In the early 1980's the Malian government requested assistance from the World Bank to help provide the country with drought-resistant water sources. The result was the Mali Rural Water Supply Project. The Project built over 600 hand pumps and worked with the government agency in charge of potable water supply (Direction Nationale de l'Hydraulique et de l'Energie, DNHE) to create a sustainable maintenance system of local pump repair technicians and a supply network of spare parts throughout the country. The system is still functioning, and India/Mali Mark II pumps (or the newer Mark III variation) continue to be installed throughout the country (Parker 1997). 


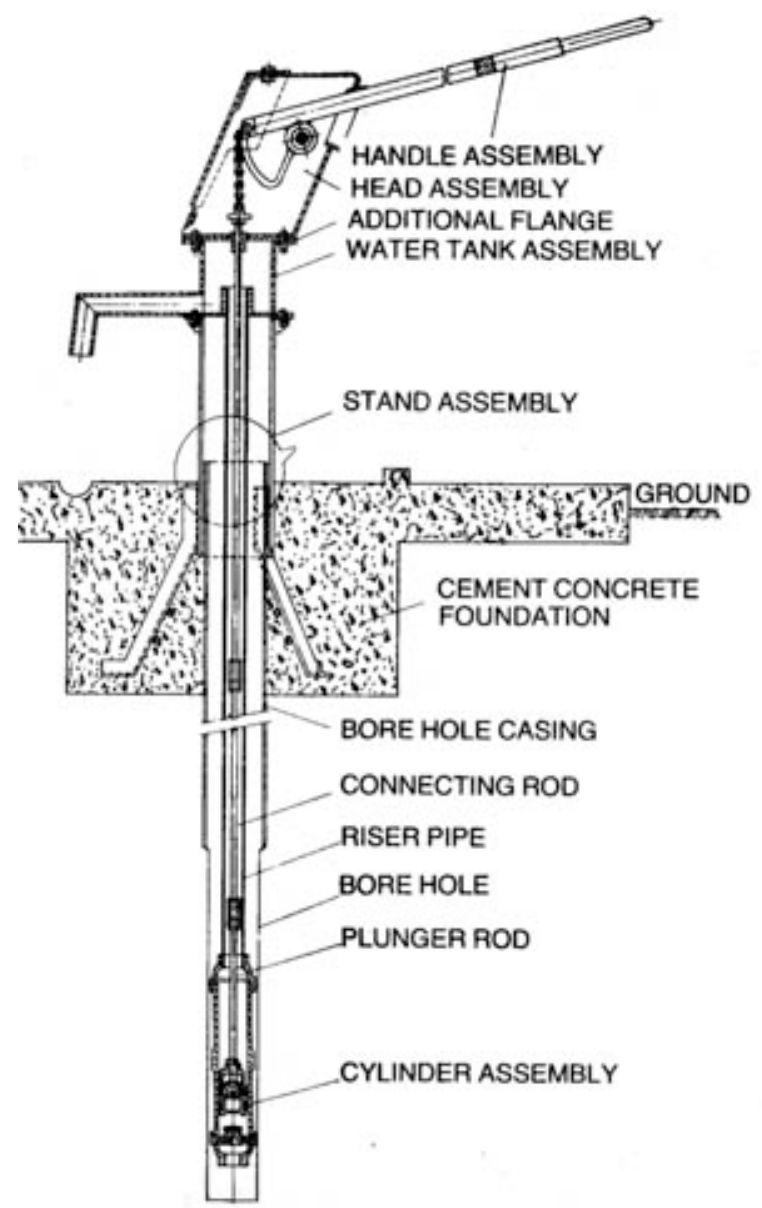

Figure 2.2 Diagram of the India Mark II hand pump (S.K. Industries 2008)

\subsubsection{Dug Wells}

Dug wells are widespread throughout Koila Bamana. Although I did not do a detailed count, I can say with confidence that at least a fifth of all compounds had a private dug well, which comes to about 50 spread throughout the village. This is not typical of most villages in Mali, where there are normally only a few dug wells for the entire community. Koila Bamana is uncommon in that the water table is easily accessible due to its close proximity to the surface (1-4 m deep during the year).

Water is extracted from dug wells using a well bag or bucket and rope. The rope is raised and lowered by hand by a person standing next to the mouth of the dug well. There is no winch or hoist erected over the dug well.

Dug wells in Koila Bamana typically have a diameter of $0.8-1.0$ meters and extend to a depth of 4-7 meters. Generally, dug wells are only lined with concrete rings for the last 
few meters at the bottom where the soil is sandy, but in some cases the entire well is lined (Figure 2.3). Dug wells that are lined from top to bottom are typically constructed with an additional ring that extends above the surface for at least half a meter. This extension is known as the top wall. Top walls made with thin-walled rings tend to disintegrate and collapse because the ropes used to draw water constantly rub along the rim of the ring. The result is that after a year or two there is no more top wall, and the mouth of the well is no longer protected. There is no apron cast around the well mouth to take away wash/spillage water (Figure 2.4).

$\underline{\text { Fully Lined Dug Well }}$

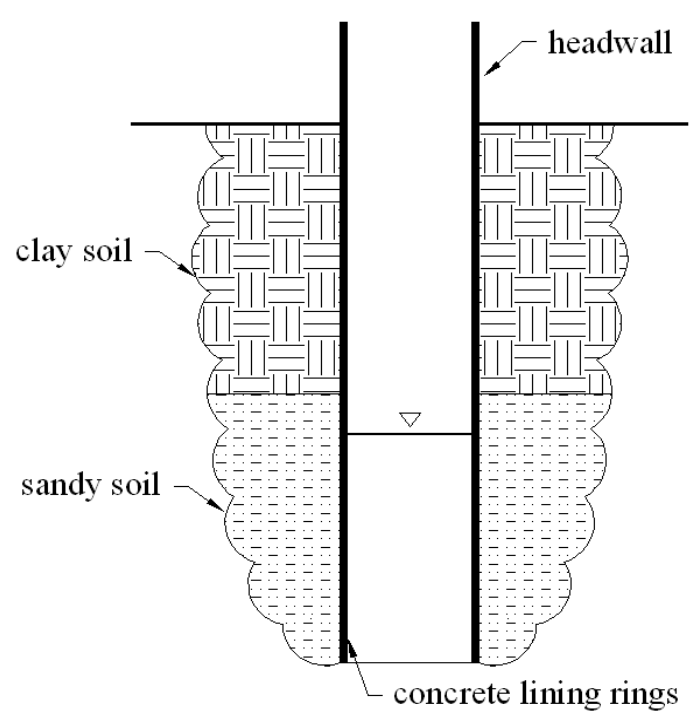

Partially Lined Dug Well

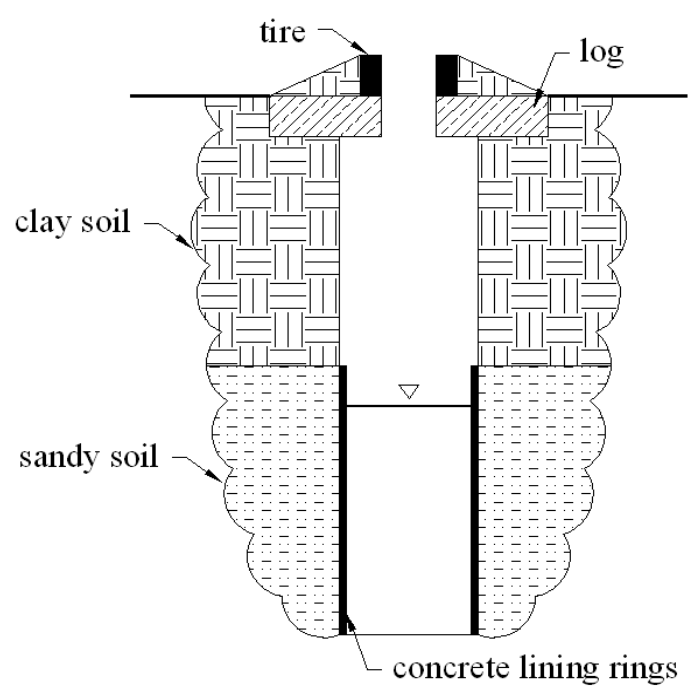

Figure 2.3 Diagrams of typical fully lined and partially lined dug well 


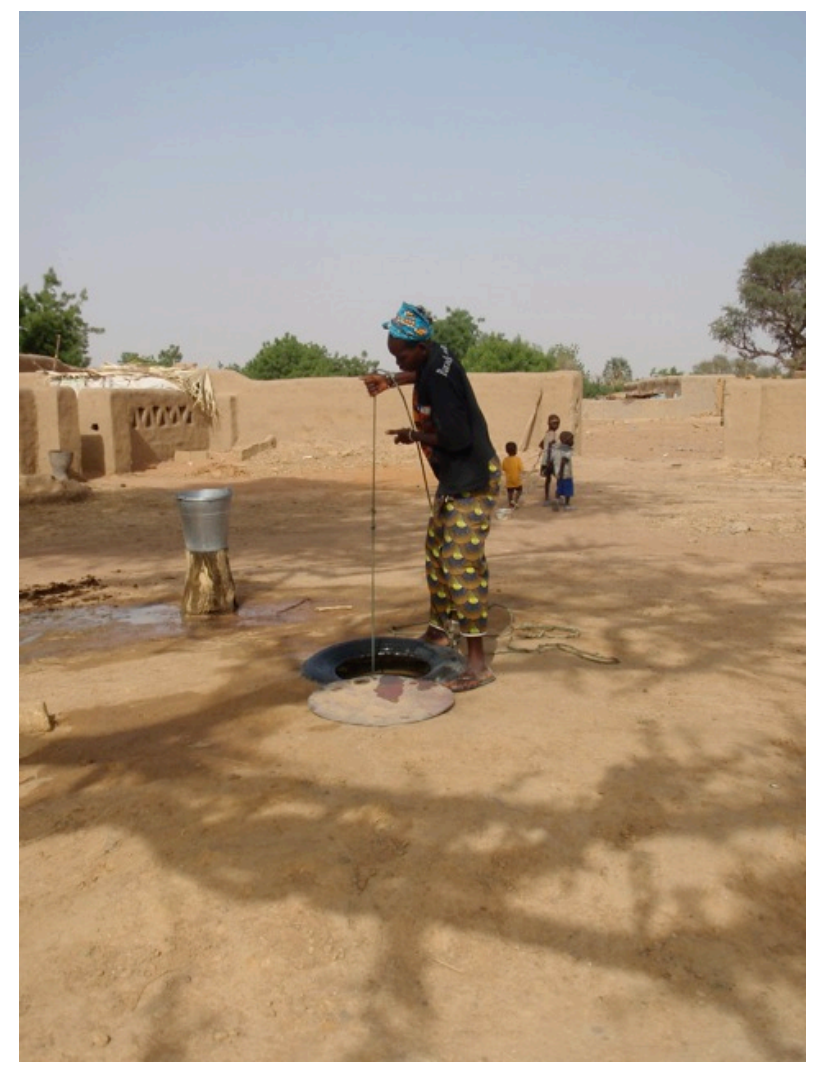

Figure 2.4 Woman using well bag to draw water from a partially lined dug well in Koila Bamana (photograph source: author)

Dug wells in Koila Bamana do not have any kind of gravel layer or other filtering mechanism placed at the bottom to prevent silting. Additionally, ring joints are not mortared which also allows silting to occur. The lack of these two elements means that a few years after construction a dug well may no longer be useful. The portion of the dug well in the water table fills with sediment. When this happens, the dug well owner will clean out the bottom, but doing so only ends up compromising structural integrity. The sandy soil immediately around the lining rings is what enters the well, so a void space is left behind. After this has happened for several years the void space becomes so large that the lining rings become unstable and the soil remaining above the void space is left unsupported. The result is a catastrophic structural failure in which the dug well collapses and becomes entirely unusable. According to the JMP, all the dug wells in Koila Bamana are categorized as unprotected because they lack either lining that extends above the ground surface to prevent runoff from entering the well or do not have a top cover to prevent bird droppings or animals from entering the well (JMP 2010). 


\subsection{Lack of Infrastructure Maintenance}

One aspect of village infrastructure in Koila Bamana that caught my attention was community reluctance to address the maintenance needs of hand pumps. A key component of the Mali Rural Water Supply Project was that individual villages are responsible for any kind of maintenance a hand pump might need. However, village responsibilities were not communicated effectively. Even now, 20 years later, villagers are still under the impression that since the government installed the boreholes and hand pumps, the government is responsible for any repairs or maintenance needed (Parker 1997). When I arrived in Koila Bamana, two of the four hand pumps were not functioning because of simple problems, but no one had taken the initiative to figure out what was wrong. Villagers thought they were not responsible for repairs and even if so, not capable of fixing the problems anyway. There is a lack of community ownership for this infrastructure.

Another factor affecting attitudes towards maintenance is that most of the adult population of Mali has more lifetime experience using dug wells. The improved wells with hand pumps are still not considered a basic necessity but rather a luxury. Because of this, if a hand pump fails, there is no sense of urgency to have it repaired. The generation responsible for making community decisions feels dug wells are still the primary water source for the community.

Through conversations with many people I also became aware of a cultural aspect that is hindering peoples' willingness to pay for hand pump maintenance. People in Koila Bamana - and much of the Malian population - believe that water is a gift from God to sustain life. Therefore, they feel there is something inherently wrong with paying for water. The idea of collecting fees for access to and maintenance of pumps is difficult to accept. There are many communities in Mali that do have a system for collecting user fees, but the idea has yet to take root in Koila Bamana.

\subsection{Poor Water Quality Strategies}

My experience in Mali has shown me that current government and development agency strategies are underperforming by not putting enough emphasis on water quality. As stated earlier, the UN's water goal is focused on increasing access (coverage). The JMP is in charge of monitoring progress towards this goal and defines access to safe drinking water as the "proportion of population using an improved drinking-water source" (WHO/UNICEF 2010). Figure 2.5 lists sources the JMP considers improved and unimproved. Additionally, the Malian government's policies for potable water focus almost entirely on access and supply. There is mention of the importance of sanitation in policy documentation, but there is no focus on water quality (Ministere des Mines de 
l'Energie et de l'Eau 2004). The Malian government, like the JMP, focuses on access, not quality.

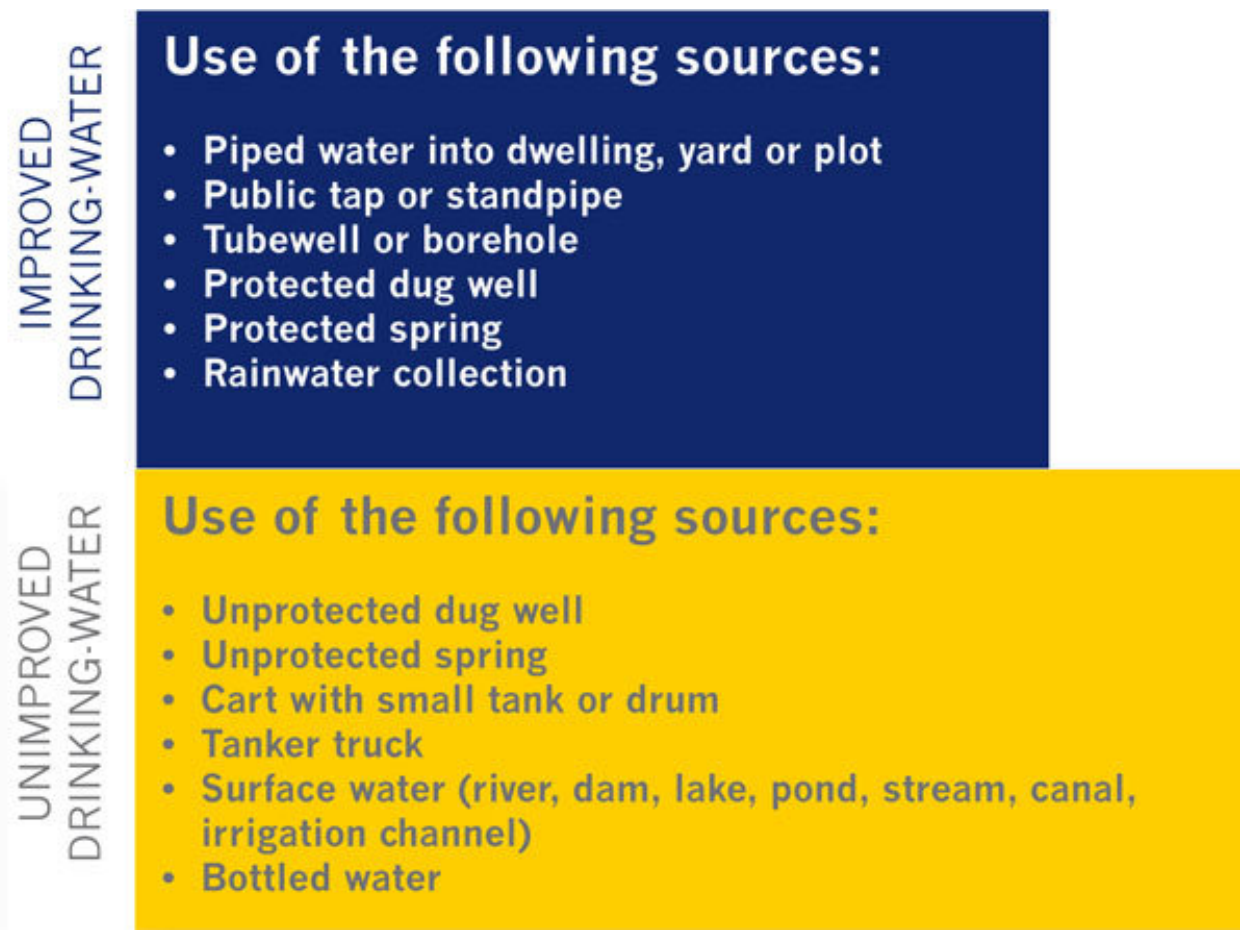

Figure 2.5 List of improved and unimproved drinking water sources according to the Joint Monitoring Programme (JMP 2010)

Peace Corps-Mali's water and sanitation training manual advises Volunteers (PCVs) to treat dug wells with bleach as a primary strategy for providing safe drinking water (Humphrey 2006). Additionally, PCVs in Mali focusing in water and sanitation work are encouraged to construct dug wells as a means to provide access to water instead of a borehole and hand pump (Traore 2011).The rationale is that people in rural settings will not maintain hand pump infrastructure or treat drinking water at point-of-use. To be effective, Volunteers are encouraged focus on projects that will be used by the people they are intended to serve. Examples to support this reasoning are listed in the next section. 


\subsection{Common Behaviors, Beliefs, and Understanding}

Most behaviors related to water collection, storage and use in Koila Bamana are not unique to that community. The following common practices have been observed elsewhere worldwide (Trevett, et al. 2004; Clasen and Bastable 2003; Jensen, et al. 2002):

- Water collected in open top buckets or jerry cans

- Buckets cleaned before use by swirling water and rubbing with a hand

- Hand-water contact is common in transit between source and household storage

- Water stored in clay pots with loose lids

- Water scooped out of clay pots with communal cup

- Hand washing not observed

- Storage containers are kept in an area that may be shared with animals

While most behaviors related to water are universal, the basis for these behaviors may be derived from different nuances in culture, beliefs and understanding. The following are simple explanations of the ideas that influence villager behavior in Koila Bamana.

No understanding of germ theory - Villagers are not fully aware of the mechanisms that cause people to become sick.

No understanding of contamination - Villagers do not have an accurate understanding of when water is contaminated or how it becomes contaminated. The only basis villagers have for contamination is if water is visibly dirty or has a foul smell.

Dug well water is "dirty" after rains - Villagers believe water from dug wells is not safe to drink for several months after rainy season. They say water from latrines has washed into the dug wells either from surface water or by flowing through the ground.

Groundwater contamination - People have a partial understanding of groundwater contamination based on their beliefs about dug well contamination after rainy season. However, they are not able to fully explain the concept and do not think that the concept applies/occurs throughout the year.

Hand pump vs. dug well water - Most people will admit that hand pump water is "better" than dug well water, although they are not able to provide detailed explanations as to why. However, most people still collect drinking water from dug wells because they prefer the taste of dug well water to hand pump water and believe there is no risk in consuming dug well water. 
Water treatment - People are aware that they can treat their dug wells with bleach, but they do not know how to do so. The idea of treating water at point-of-use is not common. Even if people are aware of water treatment options, the do not do so because they feel the cost associated with treatment outweighs the risk associated with doing nothing.

Cost of water - People believe water is a gift from God and there should be no cost associated with gaining access to it.

\subsection{Pathways for Contamination}

Most of the items listed in Section 2.4 can be considered pathways for pathogens to enter household drinking water supply. In communities with such beliefs and behaviors, contamination during collection, conveyance, and storage are legitimate concerns. Table 2.1 provides an explanation of each of the major drinking water contamination pathways observed in Koila Bamana and how they relate to each of the two types of water sources present in village. 
Table 2.1 List of contamination pathways and concerns identified for water source types (dug well, hand pump) in Koila Bamana, Mali

\begin{tabular}{|c|c|c|}
\hline Pathway & Contamination Concern & $\begin{array}{l}\text { Source } \\
\text { Type }\end{array}$ \\
\hline $\begin{array}{l}\text { Washing collection container } \\
\text { before use with unwashed } \\
\text { hands }\end{array}$ & $\begin{array}{l}\text { Person may be introducing pathogens into } \\
\text { bucket because of dirty hands. }\end{array}$ & Both \\
\hline $\begin{array}{l}\text { Hands come in contact with } \\
\text { water during transport }\end{array}$ & $\begin{array}{l}\text { Person may be introducing pathogens into } \\
\text { bucket because of dirty hands }\end{array}$ & Both \\
\hline $\begin{array}{l}\text { Storage container has loose } \\
\text { fitting lid }\end{array}$ & $\begin{array}{l}\text { Insects and dust able to enter container that } \\
\text { may have pathogens on them. }\end{array}$ & Both \\
\hline $\begin{array}{l}\text { Combining different source } \\
\text { waters in the same storage } \\
\text { container }\end{array}$ & $\begin{array}{l}\text { Person who normally uses a pathogen free } \\
\text { source may contaminate their storage } \\
\text { container with contaminated water from } \\
\text { another source. }\end{array}$ & Both \\
\hline $\begin{array}{l}\text { Communal cup dipped into } \\
\text { storage container }\end{array}$ & $\begin{array}{l}\text { The cup may carry pathogens from saliva, } \\
\text { dust, or peoples' hands into the storage } \\
\text { container. }\end{array}$ & Both \\
\hline $\begin{array}{l}\text { Source close to latrine/latrine } \\
\text { pit in water table }\end{array}$ & $\begin{array}{l}\text { Fecal contamination in groundwater may be } \\
\text { extracted by source. }\end{array}$ & Both \\
\hline Animals kept near dug well & $\begin{array}{l}\text { Large amounts of fecal material generated } \\
\text { from livestock present near dug well could } \\
\text { be tracked into dug well. }\end{array}$ & Dug Well \\
\hline Fish in dug well & Fecal material from fish in water. & Dug Well \\
\hline Children & Throw objects into dug well. & Dug Well \\
\hline Wind & Blow dust and debris into dug well. & Dug Well \\
\hline Surface water & $\begin{array}{l}\text { Seepage of contaminated wash water or rain } \\
\text { water from the surface. }\end{array}$ & Dug Well \\
\hline Well bag & $\begin{array}{l}\text { When placed on the ground, contaminated } \\
\text { soil can stick to the bag and be carried into } \\
\text { the dug well at next use. }\end{array}$ & Dug Well \\
\hline Clean out well bottom & $\begin{array}{l}\text { Person going into well introduces pathogens } \\
\text { into water from hands and feet. No treatment } \\
\text { done afterwards. }\end{array}$ & Dug Well \\
\hline
\end{tabular}




\subsection{Water Availability and Soil Conditions}

Koila Bamana is in the portion of Mali characterized as the semi-arid Sahelian zone which experiences three distinct seasons: rainy (June - November), cold (November February), and hot (February - June) (C.I.A 2009). Since all precipitation typically happens in the rainy season (see Figure 2.6), water sources are depleting available groundwater during the rest of the year until recharged in the following rainy season. This means communities in Mali that rely on dug wells are dependent on consistent annual rainfall for their water supply. Koila Bamana is bordered on three sides by extensive rice fields that are flooded annually using a system of canals and dikes that are fed by the Niger River ( $7 \mathrm{~km}$ away) (see Figure 2.7). Once the fields are flooded at the end of rainy season (October) water is held in the fields for several months and then drained so the rice can be harvested. The annual flooding means that Koila Bamana is assured good, regular groundwater recharge every year even if the area experiences a low rainfall year. As a result, the water table in Koila is fairly high, roughly 1.5 meters below the surface at the end of rainy season, but drops several meters by the end of hot season.

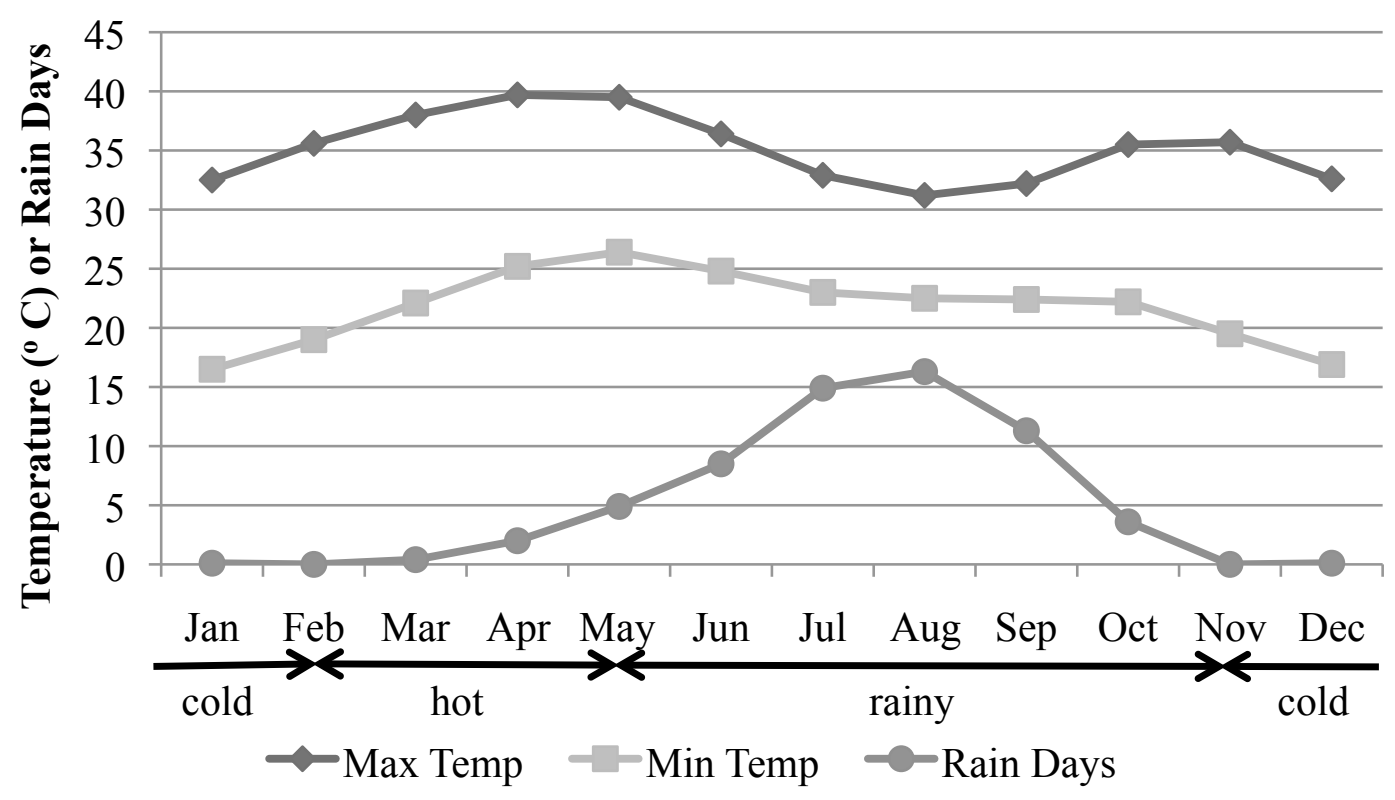

Figure 2.6 Koila Bamana average monthly maximum and minimum temperatures, average monthly rainfall days, and seasons, adapted from World Meteorological Organization (2011) 


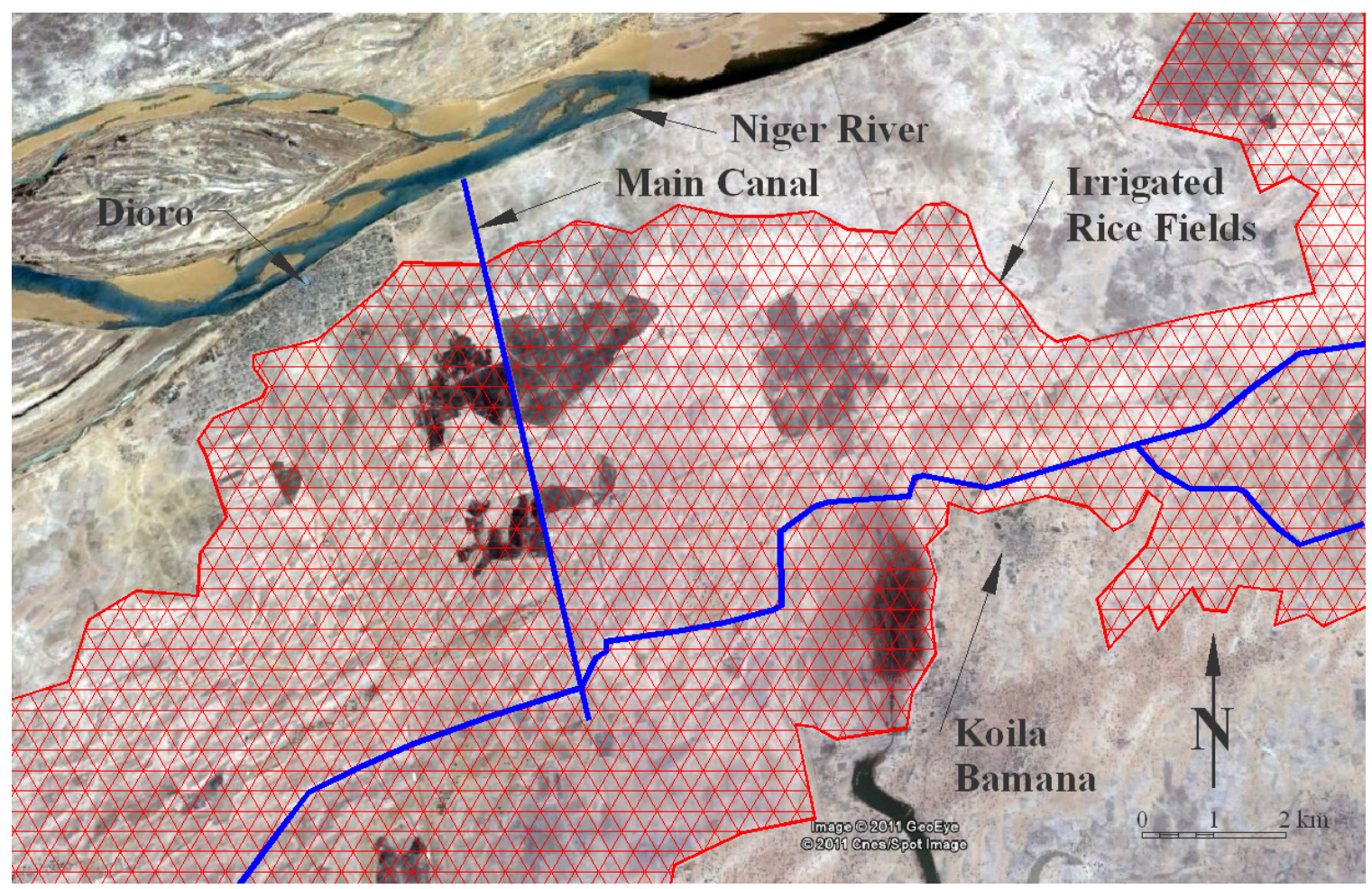

Figure 2.7 Location of Koila Bamana relative to Niger River, irrigated rice fields, and the major canal network for the area. Adapted from GeoEye and Google (2011)

Soil conditions in the area are also fairly conducive for digging wells. The first few meters of soil are consolidated silty clay, which is very hard and does not collapse. Once past the silty clay layer the soil turns into silty sand and the water table is found. Because the sand is saturated, it has a tendency to flow into the well being dug. This is where lining in the dug well usually begins to prevent the walls from collapsing.

Once this sandy layer is reached, it is difficult to continue digging a well. The hole quickly fills with water, weakening the sandy soil and causes it to flow into the well more quickly. This means that unless the well diggers work very quickly, or have some kind of pump or bailing system, they are not able to sink the well very far into the water table. Most people in Koila Bamana are not able to do this, so dug wells built by individuals tend to be fairly shallow and frequently go dry by the end of hot season. The result is that by the end of hot season (when well digging occurs) villagers are consolidating to a smaller number of sources to collect water, meaning water extraction patterns change throughout the year. The hand pumps, which draw water from an average depth of nine meters, have never gone dry in Koila Bamana. 


\section{METHODS}

To assess the state of drinking water quality at sources and points of use (households) throughout Koila Bamana microbial content (total coliform, E.coli) and turbidity were monitored. These parameters were selected because they are standard water quality indicators and are the basis for WHO drinking water quality guidelines (Payment, et al. 2003: WHO 2001). Testing was done quarterly to characterize water quality and determine if there was any variability over time. These periods were coordinated to line up with distinct times in the calendar year based on seasons: early rainy (July), late rainy (October), cold (January), and hot (April).

\subsection{Source and Household Selection}

Sampling locations included the two types of sources in village (improved wells with India/Mali Mark II hand pumps and hand-dug wells) and households getting water from each of those sources. Each of the four hand pumps, along with six dug wells and five households using each source were selected. Household selections were based on villager statements indicating that a specific source was used for drinking water collection throughout the year.

Early on, I discovered that people chose to collect drinking water from specific sources based primarily on taste. This meant that despite a large number of wells within the village (approx. 50), not all of them were used for drinking water. The system for selecting dug wells and households using them involved walking around village with a neighbor who pointed out wells that he thought were used by several families. Once five households were identified, I got permission to test water on a quarterly basis from each household and the dug well. Finding dug wells used by five or more households proved difficult because of the large number of dug wells spread throughout the village.

Households using hand pumps were selected in the same way. However, during the initial setup only three of the four hand pumps were being used to collect drinking water. As a result the testing regiment was set up to consider all four hand pumps, but only households for the three of the four being used at the time. Once all sources and households were identified (Figure 3.1) I randomly selected a third of each category to sample in triplicate across the four sampling periods 


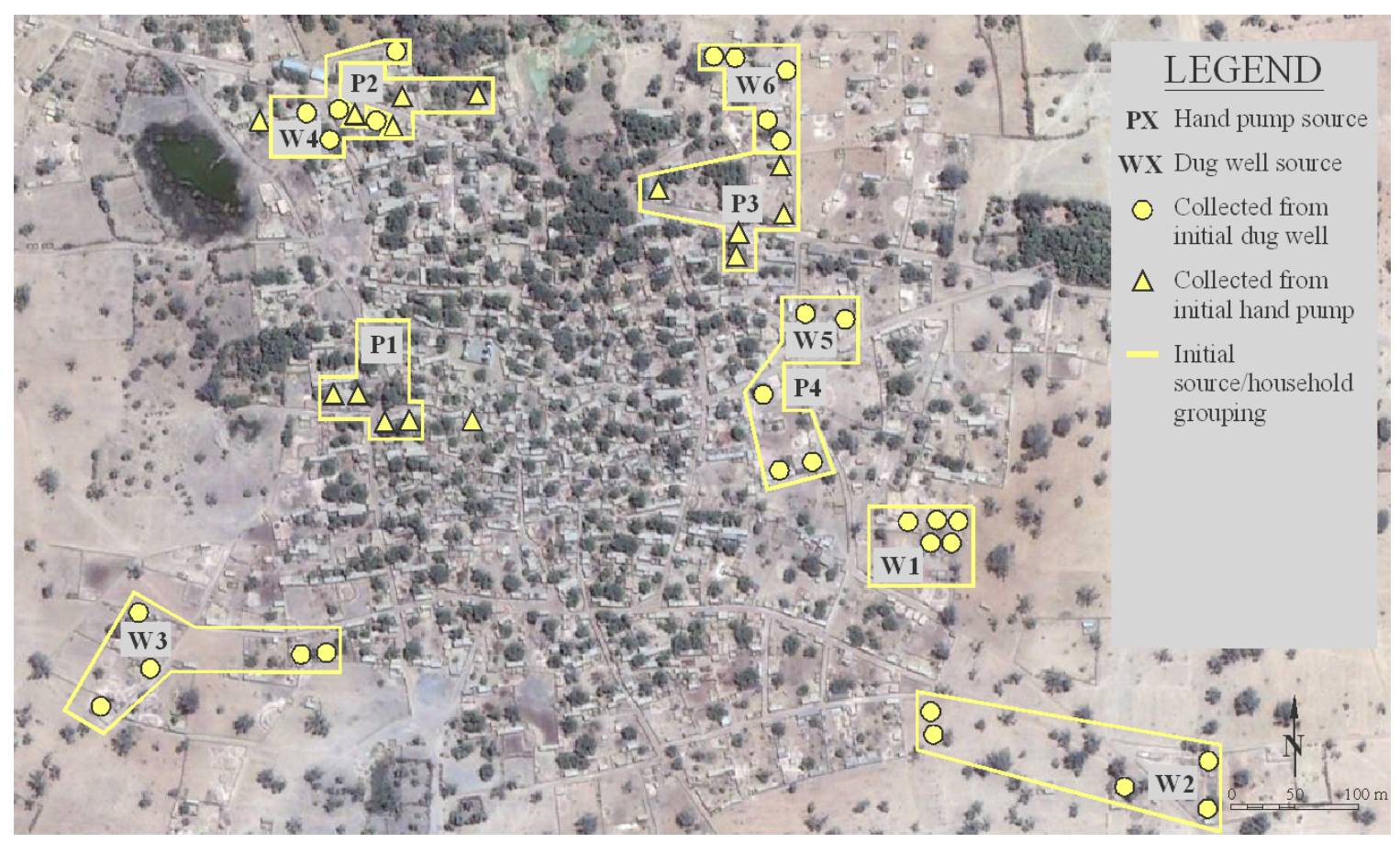

Figure 3.1 Water samples collected from ten sources ( $\mathrm{W}=$ dug well, $\mathrm{P}=$ hand pump) plus forty-five households (circular and triangular markers) during this study. Adapted from GeoEye and Google (2011)

\subsection{Petrifilm ${ }^{\mathrm{TM}}$ Testing}

Total coliform and E.coli were assessed in all water samples and soil samples taken near the mouths of dug wells. Total coliform is a standard indicator organism used to show general bacterial contamination in water. E.coli is also used to test drinking water, but points more directly to fecal contamination (Fewtrell, et al. 2001).

Typically standard methods such as membrane filtration, MPN, or chromogenic media methods are used to test for total coliform and E.coli (A. Dufour, et al. 2003). However, due to limitations in the field it was not practical to achieve strict adherence to one of these methods. Because of these limitations, a simple, low cost method was needed that did not require additional equipment. $3 \mathrm{M}$ Petrifilm ${ }^{\mathrm{TM}}$ was selected because of the simplicity of the method, low cost, and ease of transport. $3 \mathrm{M}$ Petrifilm ${ }^{\mathrm{TM}}$ was initially developed as a low cost method for food safety (3M 2011), but is considered equivalent to other commercial standard chromogenic methods for drinking water such as mColiBlue and mTEC (Vail, et al. 2003; Chuang et al. 2011). 
The Petrifilm ${ }^{\mathrm{TM}}$ method is straightforward. A $1 \mathrm{~mL}$ sample of water is placed on the count plate culture medium and left to incubate at $35^{\circ} \mathrm{C}$ for 24 hours, after which the film is read by direct count. Any total coliform or E.coli colony forming units (CFUs) appear as red or blue dots respectively (Figure 3.2). My house in Koila Bamana served as the incubator during testing as the indoor temperature remained around $35^{\circ} \mathrm{C}$ for much of the year.

$3 \mathrm{M}^{\mathrm{TM}}$ states that the count plates have a total count threshold of 150 . Anything above 150 is to be categorized as "too numerous to count" (TNTC). However, total counts can be estimated by determining the number of CFUs in one or more squares in the grid printed on the plate and then extrapolated to estimate the total count for the plate (3M 2008). I chose to do direct count up to 150 CFUs and then estimated total count if a plate had a total count higher than 150. If it was not possible to establish an estimate because of too many CFUs, the plate was given CFU total count of 1000 to represent status as TNTC. This was done to more easily facilitate qualitative and quantitative analyses.

It is also important to note that this Petrifilm ${ }^{\mathrm{TM}}$ method was used as a simple test to characterize microbial content of water. Results are to be considered as approximate because incubation was not always done at $35^{\circ} \mathrm{C}$ as required by the method. Additionally, sterile water was not available to dilute samples to a concentration that would provide total plate counts under $150 \mathrm{CFUs}$. More attention should be paid to the overall, qualitative nature of the results rather than the specific quantitative analysis shown in Chapter 4. On this basis, the practice of using a value of 1000 for plates TNTC is considered acceptable despite the value being an arbitrary representation.

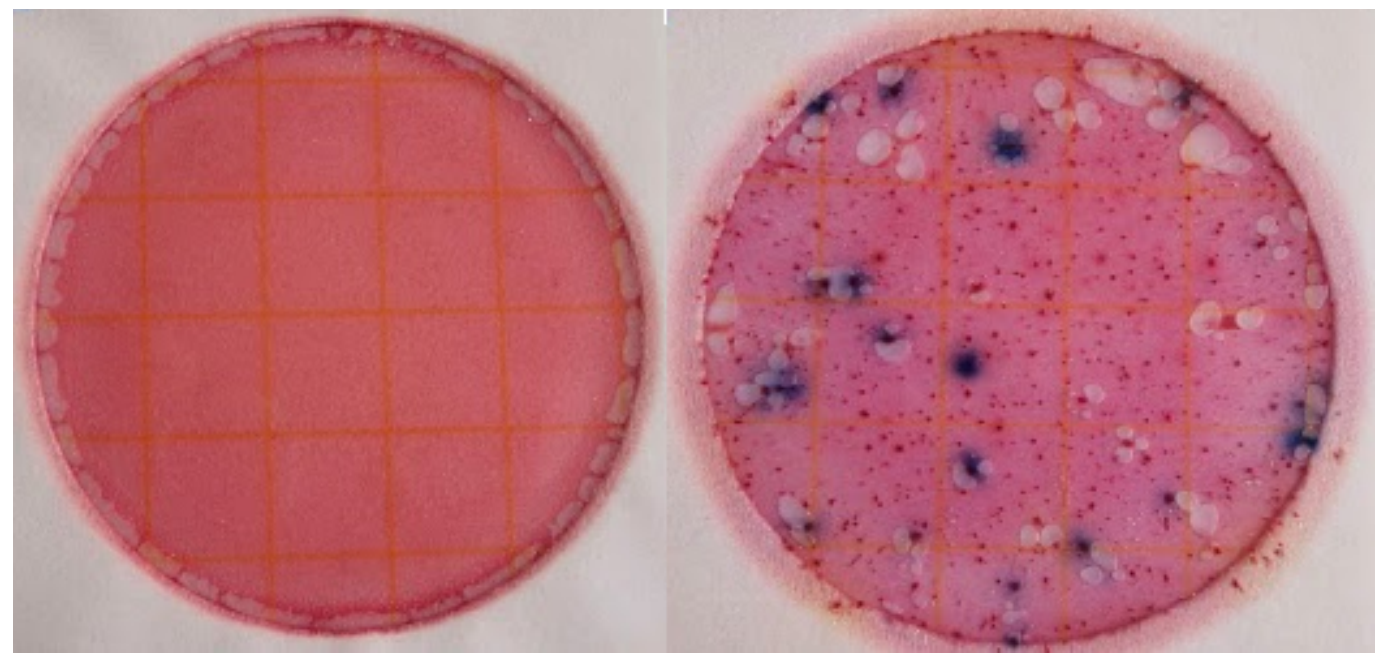

Figure 3.2 $3 \mathrm{M}^{\mathrm{TM}}$ Petrifilm ${ }^{\mathrm{TM}}$ count plates showing no bacterial contamination (left) and both total coliform and E.coli bacterial contamination (right). (source: author) 
For microbial soil testing I collected a teaspoon sized soil sample from one spot next to the mouth of each well during late rainy season. The sample was mixed with a small amount of filtered pump water and then $1 \mathrm{~mL}$ of the solution was placed on a Petrifilm ${ }^{\mathrm{TM}}$ plate to test for total coliform and E.coli. This was done to characterize the bacterial content of soil that could easily be carried into the well from normal use.

\subsection{Turbidity}

Turbidity of source water was tested because it provides a good picture of the amount of solids present. Solids can be a good vector for bacteria to enter a water source, and the more solids present, the more disinfectant required to treat a given amount of water (Davis and Lambert 2002). Turbidity, therefore, can help reinforce the results from the Petrifilms ${ }^{\mathrm{TM}}$ and determine what will be required if villagers decide to disinfect their drinking water at point-of-use.

Turbidity was measured using a homemade turbidity tube. The tube consisted of one meter of clear plastic hose that was attached vertically to a rigid, upright pipe. A one meter strip of measuring tape was secured along the hose. The top of the hose was left open, while the bottom was plugged with a Secchi disk (Math \& Science Center 2005). A small hole was poked into the hose just above the disk to allow water to slowly drain out. The tube was filled with water and then allowed to slowly drain out. The height of the water column was recorded when the Secchi disk became visible by looking down inside the tube. Turbidity was then transformed from water column height into NTUs using the following equation modified from Myre and Shaw (2006):

$$
\text { Turbidity (NTU) }=\frac{4030}{\text { Depth }(\mathrm{cm})^{1.51}}
$$

\subsection{Intervention}

After the second testing period, I began showing villagers the results from the Petrifilms ${ }^{\mathrm{TM}}$. I organized several community meetings to explain what the tests meant and encouraged people to start treating their drinking water and stop using dug wells. The treatment methods I suggested were either to use liquid bleach (sodium hypochlorite, $\mathrm{NaOCl}$ ) or Aquatabs ${ }^{\mathrm{TM}}$ (sodium dichloroisocyanurate, NaDCC), both of which are effective means of inactivating microbial contaminants (Clasen and Edmondson 2006). 


\subsection{Water Retrieval and Water Level Monitoring}

Every time I collected household samples I asked where the water had come from. If water was collected from a source different from the first sampling period (early rainy season), I noted where it had come from and why. After I began telling people about water treatment options I also began asking people if they were treating their drinking water. I also monitored depth to water table at all sources during each testing period.

\subsection{Statistical Analysis}

Once all data had been collected, my initial observations suggested that a direct comparison of results between sources could be easily made, but results at point-of-use would require more rigorous analysis. A single parametric (ANOVA) and two nonparametric (Kruskal-Wallis, Mann Whitney) statistical analyses were utilized to determine if: (1) drinking water quality at point-of-use varies based on source used; and (2) drinking water quality at point-of-use varies by season. The single parametric test (ANOVA) was used for both scenarios, whereas a different non-parametric test was used for each scenario because of the limitations of each test. Kruskal-Wallis was used to determine if water quality for a particular source varied by season because it considers three or more samples (three hand pumps and six dug wells, separately). Mann Whitney was used to determine if water quality for a particular season varied by source because it can only considers two samples (all hand pumps against all dug wells). All tests used a $95 \%$ confidence interval.

Each of the three tests is based on the null hypothesis, which assumes that all samples are from the same population, versus the alternative hypothesis that samples are not from the same population. In the context of this research, the null hypothesis is that there is no difference or variability between sources or seasons (quality is the same) versus the alternative hypothesis that there is a difference or variability (quality is different).

I chose to do parametric and non-parametric testing even though the data does not appear to follow a normal distribution (see Section 4.1). Multiple tests were used to compare results from the two types of statistical analysis. ANOVA works by comparing the averages of several populations and the variance associated with each average. KruskalWallis and Mann Whitney work by compiling all items sampled, ranking them, and then looking at the difference in location of each sample set. ANOVA is still considered a good approximation even if the data is non-normally distributed (Porkess 2006). 


\section{RESULTS}

\subsection{Data Characterization}

An initial examination of the data provides a general description of patterns and trends within categories. It should be noted that all microbial results are reported as counts per plate from $1 \mathrm{~mL}$ water samples. All concentrations are reported as CFU/mL, not as the standard CFU/100 mL concentration, because individual plates are only able to test a 1 mL sample.

All results reported are within the Petrifilm ${ }^{\mathrm{TM}}$ manufacturer's stated count range (0-150 total CFU). Table 4.1 shows that approximately one third of all sampling events were triplicated across sampling categories. Additionally the percentage of total plate counts $>150$ and too numerous to count varied across sampling categories. Figures 4.1 and 4.2 indicate low variability in normalized averages, indicating the method is consistent within the 0-150 CFU range. Tables 4.2 and 4.3 show change in percent of results across steps within the $0-150 \mathrm{CFU}$ range. Figures 4.3 and 4.4 show non-normal frequency distributions of results within the range $0-150 \mathrm{CFU}$ range.

Table 4.1 General data summary for total coliform in water samples. Values in parentheses are number of sample events in each category. TNTC is "too numerous to count" and refers to plates that were given a count of $1000 \mathrm{CFU} / \mathrm{mL}$.

\begin{tabular}{ccccc}
\hline Category & $\begin{array}{c}\text { \# of Samples } \\
\text { (n) }\end{array}$ & $\begin{array}{c}\text { \% of Sample } \\
\text { Events in Triplicate }\end{array}$ & $\begin{array}{c}\text { \% of Sample } \\
>\mathbf{1 5 0} \text { CFU Total }\end{array}$ & \% TNTC \\
\hline \hline Hand Pumps & 23 & $27 \%(15)$ & $0 \%$ & $0 \%$ \\
Dug Wells & 38 & $29 \%(24)$ & $84 \%$ & $18 \%$ \\
Hand Pump & 174 & $35 \%(102)$ & $34 \%$ & $9 \%$ \\
Households & & & & \\
Dug Wells & 117 & $32 \%(71)$ & $60 \%$ & $9 \%$ \\
Households & & & & \\
\hline
\end{tabular}




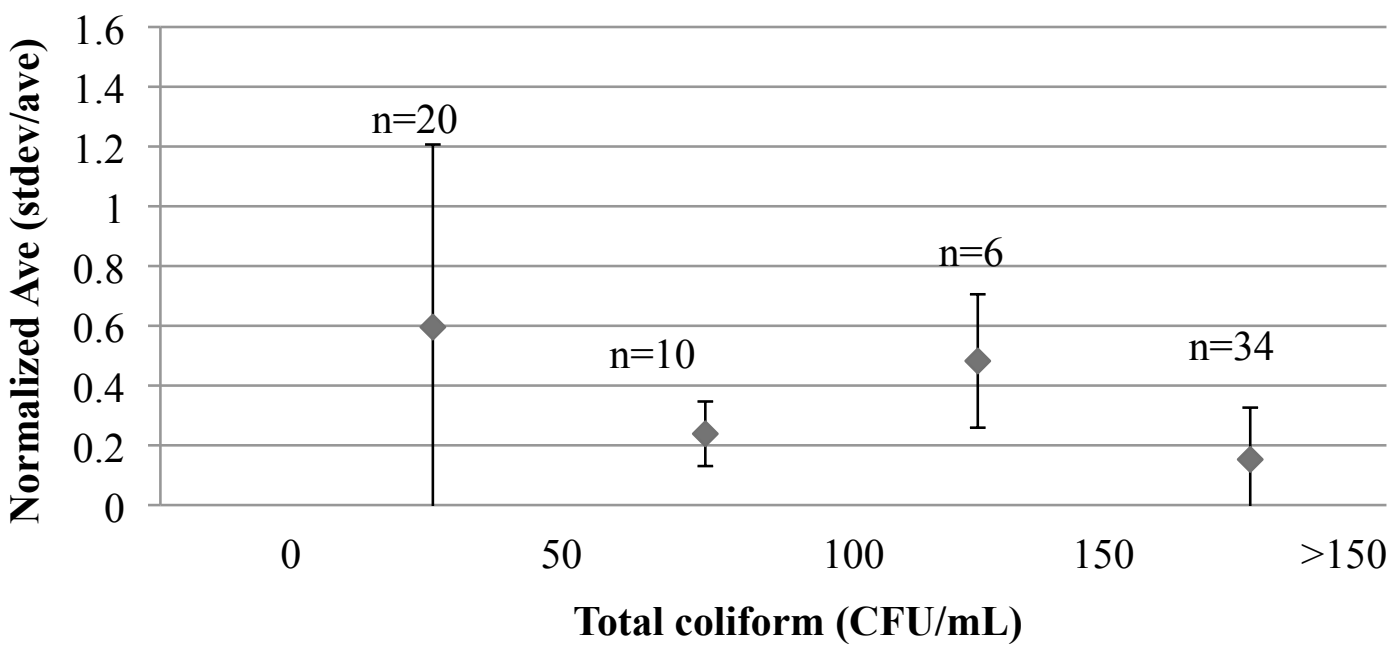

Figure 4.1 Normalized total coliform variability across sampling range using water samples evaluated in triplicate. Average values \pm one standard deviation for results in four ranges $(0-50,50-100,100-150,>150 \mathrm{CFU} / \mathrm{mL})$.

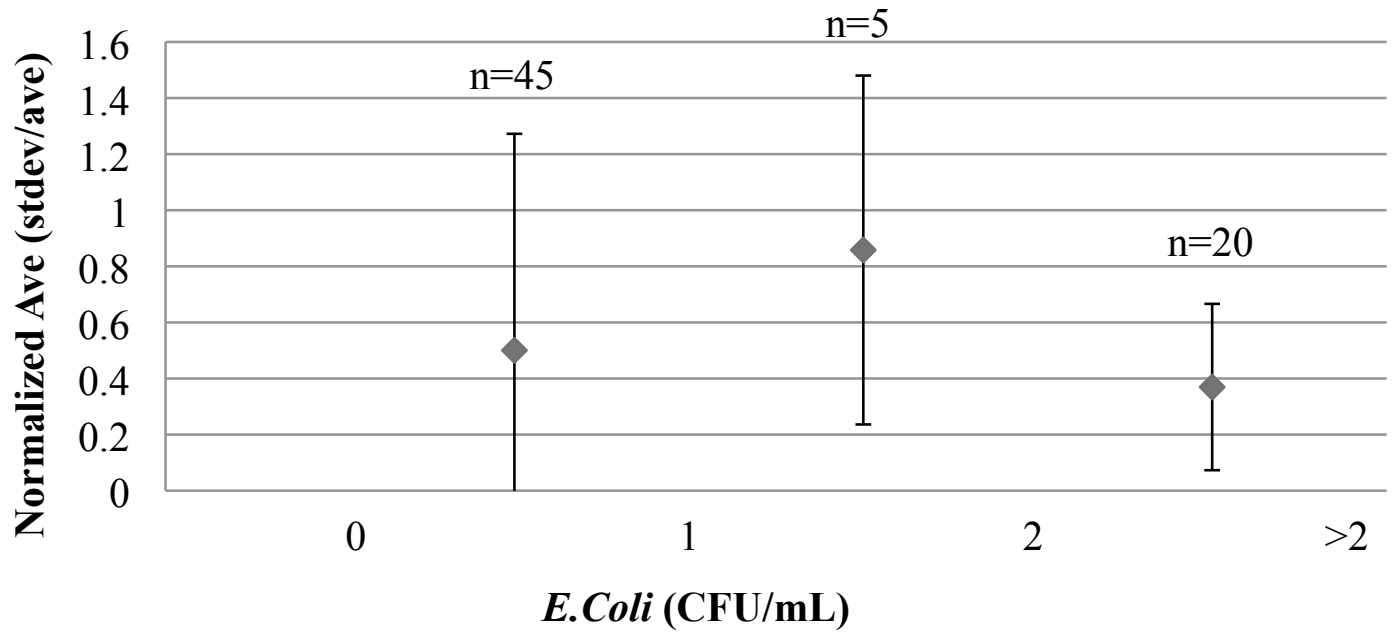

Figure 4.2 Normalized E.coli variability in data across sampling range using water samples evaluated in triplicate. Average values \pm one standard deviation for results in three ranges $(0-1,1-2,>2 \mathrm{CFU} / \mathrm{mL})$. 
Table 4.2 Total coliform characterization across data range

\begin{tabular}{ccccc}
\hline $\begin{array}{c}\text { Total } \\
\text { coliform } \\
(\mathbf{C F U} / \mathbf{m L})\end{array}$ & $\begin{array}{c}\text { Hand Pumps } \\
(\mathbf{n}=\mathbf{2 3})\end{array}$ & $\begin{array}{c}\text { Dug Wells } \\
(\mathbf{n}=\mathbf{3 8})\end{array}$ & $\begin{array}{c}\text { Hand Pump } \\
\text { Households } \\
(\mathbf{n}=\mathbf{1 7 4})\end{array}$ & $\begin{array}{c}\text { Dug Well } \\
\text { Households } \\
(\mathbf{n}=\mathbf{1 1 7})\end{array}$ \\
\hline \hline 0 & $74 \%$ & $0 \%$ & $2 \%$ & $2 \%$ \\
$>0$ & $26 \%$ & $100 \%$ & $98 \%$ & $98 \%$ \\
$>50$ & $0 \%$ & $95 \%$ & $62 \%$ & $81 \%$ \\
$>100$ & $0 \%$ & $87 \%$ & $41 \%$ & $64 \%$ \\
$>150$ & $0 \%$ & $84 \%$ & $34 \%$ & $60 \%$ \\
\hline
\end{tabular}

Table 4.3 E.coli characterization across data range

\begin{tabular}{ccccc}
\hline $\begin{array}{c}\text { E. Coli } \\
(\mathbf{C F U} / \mathbf{m L})\end{array}$ & $\begin{array}{c}\text { Hand Pumps } \\
(\mathbf{n}=\mathbf{2 3})\end{array}$ & $\begin{array}{c}\text { Dug Wells } \\
(\mathbf{n}=\mathbf{3 8})\end{array}$ & $\begin{array}{c}\text { Hand Pump } \\
\text { Households } \\
(\mathbf{n}=\mathbf{1 7 4})\end{array}$ & $\begin{array}{c}\text { Dug Well } \\
\text { Households } \\
(\mathbf{n}=\mathbf{1 1 7})\end{array}$ \\
\hline \hline 0 & $100 \%$ & $5 \%$ & $79 \%$ & $34 \%$ \\
1 & $0 \%$ & $95 \%$ & $21 \%$ & $66 \%$ \\
2 & $0 \%$ & $87 \%$ & $11 \%$ & $47 \%$ \\
$>2$ & $0 \%$ & $87 \%$ & $9 \%$ & $43 \%$ \\
\hline
\end{tabular}

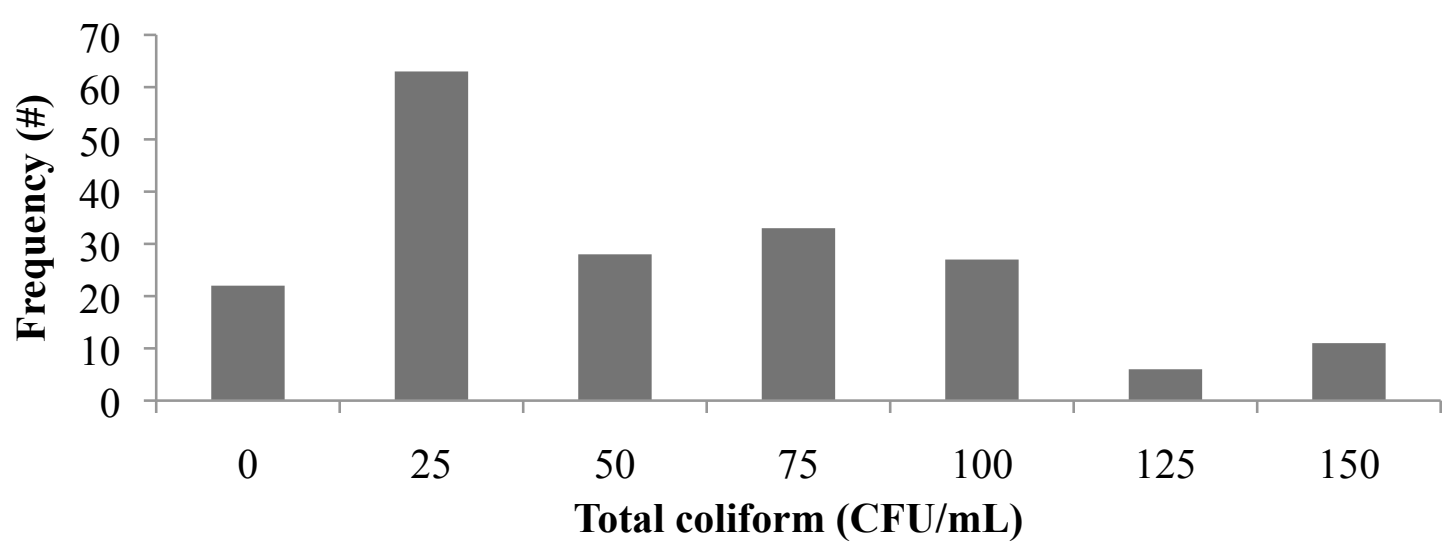

Figure 4.3 Total coliform frequency distribution for all samples in study (sources and households; $\mathrm{n}=352)$ in seven bins $(0,0-25,25-50,50-75,75-100,100-125,125-150$ $\mathrm{CFU} / \mathrm{mL}$ ). Portion above Petrifilm manufacturer's $150 \mathrm{CFU}$ total count threshold excluded $(46 \%$, or $n=162)$ 


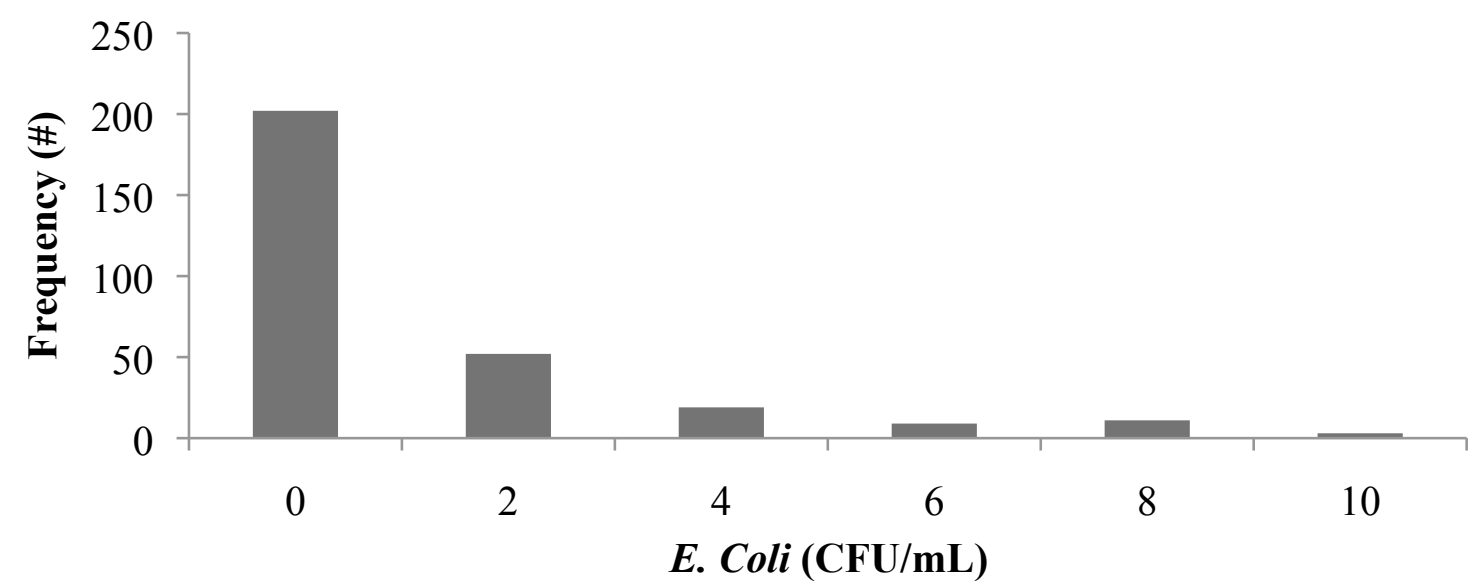

Figure 4.4 E.coli frequency distribution for all samples in study (sources and households; $\mathrm{n}=352)$ in six bins $(0,0-2,2-4,4-6,6-8,8-10 \mathrm{CFU} / \mathrm{mL})$.. Portion above 10 E.coli $\mathrm{CFU} / \mathrm{mL}$ excluded $(16 \%$, or $\mathrm{n}=56)$

\subsection{Bacterial Testing Results at Sources}

Testing for the presence of bacteria in source waters revealed a clear difference between hand pumps and dug wells. Tables 4.4 and 4.5 show that water from hand pumps (P1-P4) contained at most 3 total coliform and 0 E.coli CFUs per sampling event throughout the twelve-month period observed. (Pump P3 was not tested in late rainy season because it was broken when testing was done). However, water from dug wells (W1-W6) was in stark contrast with many having total coliform counts above the recommended total count limit for Petrifilms ${ }^{\mathrm{TM}}$. Dug wells also had an E.coli count of $1 \mathrm{CFU}$ or more at every source during every testing period. Overall, the hand pump sources had considerably better water compared to the hand dug wells (on average, 0.4 vs. $370 \mathrm{CFU}$ total coliform and 0 vs. 32 CFU E.coli). 
Table 4.4 Seasonal total coliform $(\mathrm{CFU} / \mathrm{mL})$ at hand pump $(\mathrm{P})$ or dug well $(\mathrm{W})$ water sources; $\mathrm{n}=26\left(\mathrm{P}_{\text {ave }}\right), \mathrm{n}=38(\mathrm{~W}$ ave $)$. Pairs of three indicate sampling events done in triplicate. Values of 1000 are substituted for samples with bacterial colonies too numerous to count.

\begin{tabular}{|c|c|c|c|c|c|c|c|c|c|c|c|c|}
\hline \multirow[t]{2}{*}{ Source } & \multicolumn{12}{|c|}{ Source } \\
\hline & P1 & $\mathbf{P 2}$ & $\mathbf{P 3}$ & $\mathbf{P 4}$ & $\mathbf{P}_{\text {ave }}$ & W1 & W2 & $\mathbf{W 3}$ & W4 & W5 & W6 & $\mathbf{W}_{\text {ave }}$ \\
\hline Early Rainy & $\overline{0}$ & 3 & $\overline{0}$ & $\overline{0}$ & 0.8 & $\overline{175,90,60}$ & 400 & 500 & 600 & 220 & $300,200,350$ & 352 \\
\hline Late Rainy & 0 & 0 & - & 0 & 0.0 & 450 & $400,400,400$ & 500 & 180 & 1000 & 1000 & 577 \\
\hline Cold & $0,0,1$ & $2,2,2$ & 0 & 0 & 0.6 & 36 & 340 & 21 & $320,200,160$ & 55 & 120 & 133 \\
\hline Hot & $0,1,1$ & $0,0,0$ & 0 & 0 & 0.1 & 300 & 230 & 500 & 180 & 300 & $1000,1000,1000$ & 418 \\
\hline Annual $_{\text {ave }}$ & 0.2 & 1.3 & 0 & 0 & 0.4 & 224 & 343 & 364 & 297 & 394 & 601 & 370 \\
\hline
\end{tabular}

Table 4.5 Seasonal E.coli $(\mathrm{CFU} / \mathrm{mL})$ at hand pump $(\mathrm{P})$ or dug well $(\mathrm{W})$ water sources; $\mathrm{n}=26\left(\mathrm{P}_{\mathrm{ave}}\right), \mathrm{n}=38\left(\mathrm{~W}_{\mathrm{ave}}\right)$. Pairs of three indicate sampling events done in triplicate. 601,370

\begin{tabular}{|c|c|c|c|c|c|c|c|c|c|c|c|c|}
\hline \multirow{2}{*}{ Source } & \multicolumn{12}{|c|}{ Source } \\
\hline & P1 & P2 & P3 & P4 & $\mathbf{P}_{\text {ave }}$ & W1 & $\mathbf{W 2}$ & W3 & W4 & W5 & W6 & $\mathbf{W}_{\text {ave }}$ \\
\hline Early Rainy & 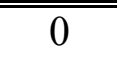 & 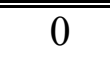 & 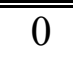 & 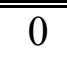 & 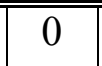 & $1,1,0,0$ & 16 & 12 & 25 & 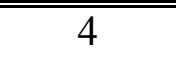 & $25,8,11$ & 1212 \\
\hline Late Rainy & 0 & 0 & - & 0 & 0 & 3 & $80,85,65$ & $21,27,29$ & 8 & $16,17,10$ & 120 & 42 \\
\hline Cold & $0,0,0$ & $0,0,0$ & 0 & 0 & 0 & 3 & 32 & 5 & $8,4,1$ & 1 & 5 & 8 \\
\hline Hot & $0,0,0$ & $0,0,0$ & 0 & 0 & 0 & 3 & 30 & 8 & 5 & 5 & $350,350,350$ & 67 \\
\hline Annual $_{\mathrm{ave}}$ & 0 & 0 & 0 & 0 & $\mathbf{0}$ & 2.5 & 39 & 13 & 11 & 6 & 123 & 32 \\
\hline
\end{tabular}




\subsection{Bacterial Testing Results at Point-of-Use}

Testing at point-of-use (households) was done to characterize the quality of water coming out of the "cup" compared to the "tap" (at the water source). Analysis at point-of-use was set up to determine if there were: (1) seasonal differences in water quality at point-of-use, and (2) water quality degradation at point-of-use coming from hand pumps. Tables 4.6 to 4.9 compare percent of incidence across various levels within the $0-150 \mathrm{CFU} / \mathrm{mL}$ range for water samples from sources and households. Tables 4.6 and 4.7 show total coliform contamination at point of use is more prevalent for households using dug wells. Tables 4.8 and 4.9 show similar results for E.coli.

Table 4.6 Incidence rates ( $\%$ of samples) for total coliform in hand pump water samples at source and household

\begin{tabular}{|c|c|c|c|c|c|c|c|c|}
\hline \multirow{2}{*}{$\begin{array}{c}\text { Total } \\
\text { Coliform } \\
(\mathrm{CFU} / \mathrm{mL})\end{array}$} & \multicolumn{2}{|c|}{ Early Rainy } & \multicolumn{2}{|c|}{ Late Rainy } & \multicolumn{2}{|c|}{ Cold } & \multicolumn{2}{|c|}{ Hot } \\
\hline & $\begin{array}{c}\text { Hand } \\
\text { Pumps } \\
(n=4)\end{array}$ & $\begin{array}{c}\text { House- } \\
\text { holds } \\
(n=29)\end{array}$ & $\begin{array}{c}\text { Hand } \\
\text { Pumps } \\
(n=3)\end{array}$ & $\begin{array}{c}\text { House- } \\
\text { holds } \\
(n=61)\end{array}$ & $\begin{array}{c}\text { Hand } \\
\text { Pumps } \\
(n=8)\end{array}$ & $\begin{array}{c}\text { House- } \\
\text { holds } \\
(n=56)\end{array}$ & $\begin{array}{c}\text { Hand } \\
\text { Pumps } \\
(n=8)\end{array}$ & $\begin{array}{c}\text { House- } \\
\text { holds } \\
(n=28)\end{array}$ \\
\hline$\overline{00}$ & $75 \%$ & $\overline{7 \%}$ & $100 \%$ & $0 \%$ & $50 \%$ & $0 \%$ & $83 \%$ & $4 \%$ \\
\hline$>0$ & $25 \%$ & $93 \%$ & $0 \%$ & $100 \%$ & $50 \%$ & $100 \%$ & $17 \%$ & $96 \%$ \\
\hline$>50$ & $0 \%$ & $69 \%$ & $0 \%$ & $79 \%$ & $0 \%$ & $46 \%$ & $0 \%$ & $54 \%$ \\
\hline$>100$ & $0 \%$ & $34 \%$ & $0 \%$ & $66 \%$ & $0 \%$ & $16 \%$ & $0 \%$ & $46 \%$ \\
\hline$>150$ & $0 \%$ & $28 \%$ & $0 \%$ & $56 \%$ & $0 \%$ & $16 \%$ & $0 \%$ & $36 \%$ \\
\hline
\end{tabular}

Table 4.7 Incidence rates ( $\%$ of samples) for total coliform in dug well water samples at source and household

\begin{tabular}{ccccccccc}
\hline $\begin{array}{c}\text { Total } \\
\text { Coliform }\end{array}$ & \multicolumn{2}{c}{ Early Rainy } & \multicolumn{2}{c}{ Late Rainy } & \multicolumn{2}{c}{ Cold } & \multicolumn{2}{c}{ Hot } \\
Duf & House- & Dug & House- & Dug & House- & Dug & House- \\
& Wells & holds & Wells & holds & Wells & holds & Wells & holds \\
& $(\mathbf{n = 1 0 )}$ & $(\mathbf{n = 5 2 )}$ & $\mathbf{( n = 1 2 )}$ & $\mathbf{( n = 1 9 )}$ & $\mathbf{( n = 8 )}$ & $\mathbf{( n = 1 9 )}$ & $\mathbf{( n = 8 )}$ & $(\mathbf{n = 2 7 )}$ \\
\hline \hline 0 & $0 \%$ & $0 \%$ & $0 \%$ & $0 \%$ & $0 \%$ & $11 \%$ & $0 \%$ & $0 \%$ \\
$>0$ & $100 \%$ & $100 \%$ & $100 \%$ & $100 \%$ & $100 \%$ & $89 \%$ & $100 \%$ & $100 \%$ \\
$>50$ & $100 \%$ & $88 \%$ & $100 \%$ & $79 \%$ & $71 \%$ & $47 \%$ & $100 \%$ & $93 \%$ \\
$>100$ & $80 \%$ & $73 \%$ & $100 \%$ & $74 \%$ & $57 \%$ & $16 \%$ & $100 \%$ & $74 \%$ \\
$>150$ & $80 \%$ & $71 \%$ & $100 \%$ & $58 \%$ & $43 \%$ & $16 \%$ & $100 \%$ & $70 \%$ \\
\hline
\end{tabular}


Table 4.8 Incidence rates (\% of samples) for E. Coli in hand pump water samples at source and household

\begin{tabular}{|c|c|c|c|c|c|c|c|c|}
\hline \multirow{2}{*}{$\begin{array}{c}\text { E. Coli } \\
(\mathrm{CFU} / \mathrm{mL})\end{array}$} & \multicolumn{2}{|c|}{ Early Rainy } & \multicolumn{2}{|c|}{ Late Rainy } & \multicolumn{2}{|c|}{ Cold } & \multicolumn{2}{|c|}{ Hot } \\
\hline & $\begin{array}{c}\text { Hand } \\
\text { Pumps } \\
(n=4)\end{array}$ & $\begin{array}{c}\text { House- } \\
\text { holds } \\
(n=29)\end{array}$ & $\begin{array}{c}\text { Hand } \\
\text { Pumps } \\
(n=3)\end{array}$ & $\begin{array}{c}\text { House- } \\
\text { holds } \\
(n=61)\end{array}$ & $\begin{array}{c}\text { Hand } \\
\text { Pumps } \\
(n=8)\end{array}$ & $\begin{array}{c}\text { House- } \\
\text { holds } \\
(n=56)\end{array}$ & $\begin{array}{c}\text { Hand } \\
\text { Pumps } \\
(n=8)\end{array}$ & $\begin{array}{c}\text { House- } \\
\text { holds } \\
(n=28)\end{array}$ \\
\hline 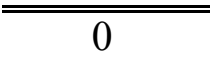 & $100 \%$ & $76 \%$ & $100 \%$ & $69 \%$ & $100 \%$ & $88 \%$ & $100 \%$ & $82 \%$ \\
\hline 1 & $0 \%$ & $24 \%$ & $0 \%$ & $31 \%$ & $50 \%$ & $12 \%$ & $0 \%$ & $18 \%$ \\
\hline 2 & $0 \%$ & $7 \%$ & $0 \%$ & $23 \%$ & $0 \%$ & $2 \%$ & $0 \%$ & $14 \%$ \\
\hline$>2$ & $0 \%$ & $7 \%$ & $0 \%$ & $15 \%$ & $0 \%$ & $2 \%$ & $0 \%$ & $14 \%$ \\
\hline
\end{tabular}

Table 4.9 Incidence rates (\% of samples) for E. Coli in dug well water samples at source and household

\begin{tabular}{|c|c|c|c|c|c|c|c|c|}
\hline \multirow{2}{*}{$\begin{array}{c}\text { E. Coli } \\
(\mathrm{CFU} / \mathrm{mL})\end{array}$} & \multicolumn{2}{|c|}{ Early Rainy } & \multicolumn{2}{|c|}{ Late Rainy } & \multicolumn{2}{|c|}{ Cold } & \multicolumn{2}{|c|}{ Hot } \\
\hline & $\begin{array}{c}\text { Dug } \\
\text { Wells } \\
(n=10)\end{array}$ & $\begin{array}{c}\text { House- } \\
\text { holds } \\
(n=52)\end{array}$ & $\begin{array}{c}\text { Dug } \\
\text { Wells } \\
(n=12)\end{array}$ & $\begin{array}{c}\text { House- } \\
\text { holds } \\
(n=19)\end{array}$ & $\begin{array}{c}\text { Dug } \\
\text { Wells } \\
(n=8)\end{array}$ & $\begin{array}{c}\text { House- } \\
\text { holds } \\
(n=19)\end{array}$ & $\begin{array}{c}\text { Dug } \\
\text { Wells } \\
(n=8)\end{array}$ & $\begin{array}{c}\text { House- } \\
\text { holds } \\
(n=27)\end{array}$ \\
\hline 0 & $20 \%$ & $29 \%$ & $0 \%$ & $37 \%$ & $0 \%$ & $47 \%$ & $0 \%$ & $33 \%$ \\
\hline 1 & $80 \%$ & $71 \%$ & $100 \%$ & $63 \%$ & $100 \%$ & $53 \%$ & $100 \%$ & $67 \%$ \\
\hline 2 & $70 \%$ & $46 \%$ & $100 \%$ & $42 \%$ & $86 \%$ & $37 \%$ & $100 \%$ & $59 \%$ \\
\hline$>2$ & $70 \%$ & $42 \%$ & $100 \%$ & $37 \%$ & $86 \%$ & $32 \%$ & $100 \%$ & $56 \%$ \\
\hline
\end{tabular}

Analysis of results has been split into two categories: plates with a total count $\leq 150$ and all plates, regardless of count. The split was done to show the difference in results when following 3M's guidelines for a maximum counting range (0-150 CFU) and when considering the entire range of results. Tables 4.4 and 4.9 (above) indicate that only considering plates with a total count $\leq 150$ would exclude large portions of the data from analysis.

For plates with a total count $\leq 150$, Tables 4.10 and 4.11 shows slight differences in total coliform and E.coli between households associated with hand pumps and dug wells. For all plates, regardless of count, results are expectedly more pronounced. However, despite differences in annual averages for both Tables 4.10 and 4.11 , observation is not a sufficient basis to state whether seasonal microbial differences exist at point-of-use. In order to make such a determination, statistical analysis is required. 
Table 4.10 Total coliform (CFU/mL) averages at households, comparing effect of inclusion or exclusion of values $>150$. Values in parentheses are number of samples.

\begin{tabular}{|c|c|c|c|c|c|c|c|c|c|}
\hline \multirow{3}{*}{$\begin{array}{c}\begin{array}{c}\text { Total } \\
(\mathrm{CFU} / \mathrm{mL})\end{array} \\
<=150\end{array}$} & \multirow[t]{2}{*}{ Source } & \multicolumn{8}{|c|}{ Season } \\
\hline & & \multicolumn{2}{|c|}{ Early } & \multicolumn{2}{|c|}{ Late Rainy } & \multicolumn{2}{|c|}{ Cold } & Hot & \multirow{2}{*}{\begin{tabular}{|c} 
Annual $_{\text {ave }}$ \\
50
\end{tabular}} \\
\hline & Hand Pump & 58 & (21) & 64 & (27) & 38 & $(48)$ & $40 \quad(18)$ & \\
\hline & Dug & 62 & (15) & 75 & (8) & 38 & (16) & $72 \quad(8)$ & 62 \\
\hline \multirow[t]{2}{*}{ All } & Hand Pump & 118 & (29) & 264 & (61) & 118 & (56) & $229(28)$ & 182 \\
\hline & Dug Well & 369 & (52) & 323 & (19) & 97 & (19) & 439 (26) & 307 \\
\hline
\end{tabular}

Table 4.11 E. Coli (CFU/mL) averages at households, comparing effect of inclusion or exclusion of values associated with total colony counts $>150$. Values in parentheses are number of samples.

\begin{tabular}{|c|c|c|c|c|c|c|c|}
\hline \multirow{3}{*}{$\begin{array}{c}\begin{array}{c}E . c o l i \\
(\mathrm{CFU} / \mathrm{mL})\end{array} \\
\end{array}$} & \multirow[t]{2}{*}{ Source } & \multicolumn{6}{|c|}{ Season } \\
\hline & & Early & Rainy & Late Rainy & Cold & Hot & \multirow{2}{*}{\begin{tabular}{|c} 
Annual $_{\text {ave }}$ \\
0.2
\end{tabular}} \\
\hline & 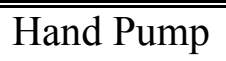 & $\overline{0.2}$ & (21) & $\begin{array}{ll}0.6 & (27)\end{array}$ & $\begin{array}{ll}0.1 \quad(48) \\
\end{array}$ & 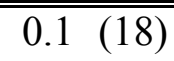 & \\
\hline & Duq & 0.9 & (15) & 2.0 & $1.1 \quad$ (16) & $0.4 \quad(8)$ & 1.1 \\
\hline \multirow[t]{2}{*}{ All } & Hand & 0.4 & (29) & $\begin{array}{ll}1.9 \quad(61) \\
\end{array}$ & $0.1 \quad(56)$ & $2.0(28)$ & 1.1 \\
\hline & Dug Well & 6.6 & (52) & $15.8 \quad(19)$ & $6.8 \quad$ (19) & $17.3(26)$ & 11.6 \\
\hline
\end{tabular}

\subsubsection{Point-of-Use Variability Based on Source}

Interpretation is based on results from the Kruskal-Wallis test. ANOVA test results are provided as an approximate comparison. For plates with a total count $\leq 150$, Table 4.12 shows no seasonal variability (total coliform and E.coli) for households using different source types. For all plates, regardless of count, Table 4.13 shows seasonal total coliform variability, but no E.coli variability for households using different source types. Table 4.12 indicates consistent water quality throughout the year at point-of-use for each source type used when considering a total count range of 0-150 CFU/mL. Table 4.13 shows variable quality for total coliform when considering all plates regardless of count. 
Table 4.12 Point-of-use comparison for change in seasonal microbial contamination based on source used (using total count $\leq 150$ data only; result of "same" means no seasonal variability at $95 \%$ confidence)

\begin{tabular}{ccccc}
\hline Source & \multicolumn{2}{c}{ Total Coliform } & \multicolumn{2}{c}{ E.coli } \\
& ANOVA & Kruskal-Wallis & ANOVA & Kruskal-Wallis \\
\hline \hline Hand Pumps & different & same & same & same \\
Dug Wells & same & same & same & same \\
\hline
\end{tabular}

Table 4.13 Point-of-use comparison for change in seasonal microbial contamination based on source used (using all data; result of "same" means no seasonal variability at $95 \%$ confidence)

\begin{tabular}{ccccc}
\hline Source & \multicolumn{2}{c}{ Total Coliform } & \multicolumn{2}{c}{ E.coli } \\
& ANOVA & Kruskal-Wallis & ANOVA & Kruskal-Wallis \\
\hline \hline Hand Pumps & different & different & different & same \\
Dug Wells & different & different & same & same \\
\hline
\end{tabular}

\subsubsection{Point-of-Use Variability Based on Season}

Interpretation is based on results from the Mann Whitney test. ANOVA test results are provided as an approximate comparison. For plates with a total count $\leq 150$, Table 4.14 shows total coliform variability for hot season and E.coli variability for early rainy and cold seasons. For all plates, regardless of count, Table 4.15 shows total coliform variability for early rainy and hot seasons and E.coli variability for all seasons. Table 4.14 indicates that for half the year water originating from hand pumps and dug wells cannot be distinguished at point-of-use when considering total count range of 0-150 $\mathrm{CFU} / \mathrm{mL}$. Table 4.15 indicates that water from hand pumps and dug wells can be distinguished (i.e. have different quality) at point-of-use when considering all water sample data regardless of bacterial count. 
Table 4.14 Point-of-use comparison for change in microbial contamination based on source for individual seasons (using plate count $\leq 150$ data only; result of "same" means there is no difference in water quality between the two source types at $95 \%$ confidence)

\begin{tabular}{ccccc}
\hline Season & \multicolumn{2}{c}{ Total Coliform } & \multicolumn{2}{c}{ E.coli } \\
& ANOVA & Mann Whitney & ANOVA & Mann Whitney \\
\hline \hline Early Rainy & same & same & different & different \\
Late Rainy & same & same & same & same \\
Cold & same & same & different & different \\
Hot & same & different & same & same \\
\hline
\end{tabular}

Table 4.15 Point-of-use comparison for change in microbial contamination based on source for individual seasons (using all data; result of "same" means there is no difference in water quality between the two source types at $95 \%$ confidence)

\begin{tabular}{ccccc}
\hline Season & \multicolumn{2}{c}{ Total Coliform } & \multicolumn{2}{c}{ E.coli } \\
& ANOVA & Mann Whitney & ANOVA & Mann Whitney \\
\hline \hline Early Rainy & different & different & different & different \\
Late Rainy & same & same & different & different \\
Cold & same & same & different & different \\
Hot & different & different & same & different \\
\hline
\end{tabular}

\subsection{Bacterial Soil Testing Results at Dug Wells}

Total coliform results for all soil samples had CFU counts that were TNTC, which are represented in Table 4.16 by a value of " 1000 ". E.coli results also had very high counts. Unexpectedly, dug wells W3 and W5 had an E.coli count of 0, which cannot be explained. 
Table 4.16 Characterization of soil bacterial content next to mouth of dug wells (CFU/mL of solution tested)

\begin{tabular}{ccc}
\hline Dug Well & \multicolumn{2}{c}{ Plate Count } \\
& Total Coliform & E.coli \\
\hline \hline W1 & 1000 & 150 \\
W2 & 1000 & 300 \\
W3 & 1000 & 0 \\
W4 & 1000 & 220 \\
W5 & 1000 & 0 \\
W6 & 1000 & 220 \\
\hline
\end{tabular}

\subsection{Depth to Groundwater}

Depth to groundwater was measured seasonally with results as expected (Figure 4.5). The water table is closest to the surface at the end of rainy season because of recharge from rainfall. Once the rains are finished, the water table begins to drop in cold season, but only slightly because of recharge that is occurring from the flooded rice fields surrounding the village. Drawdown accelerates in hot season because there is no recharge coming from rain or the rice fields. Drawdown continues up to early rainy season when the rains begin again.

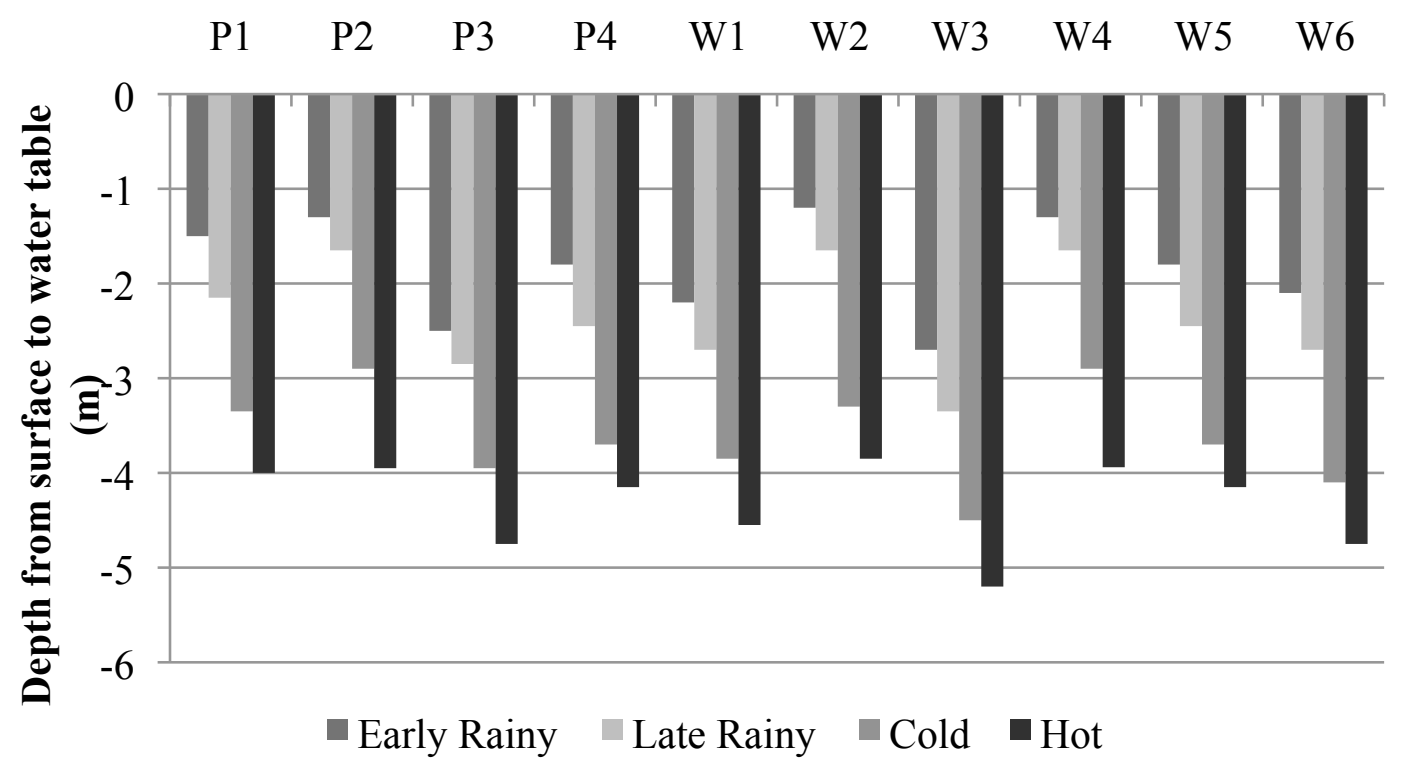

Figure 4.5 Seasonal change in depth to water table for hand pumps (P) and dug wells (W) in Koila Bamana, Mali (2010-2011). 


\subsection{Source Water Turbidity}

Turbidity for all hand pumps (P1 - P4) was below 5 NTUs for all seasons. The general trend for dug wells (W1-W6) is an increase in turbidity with each season (Figure 4.6).

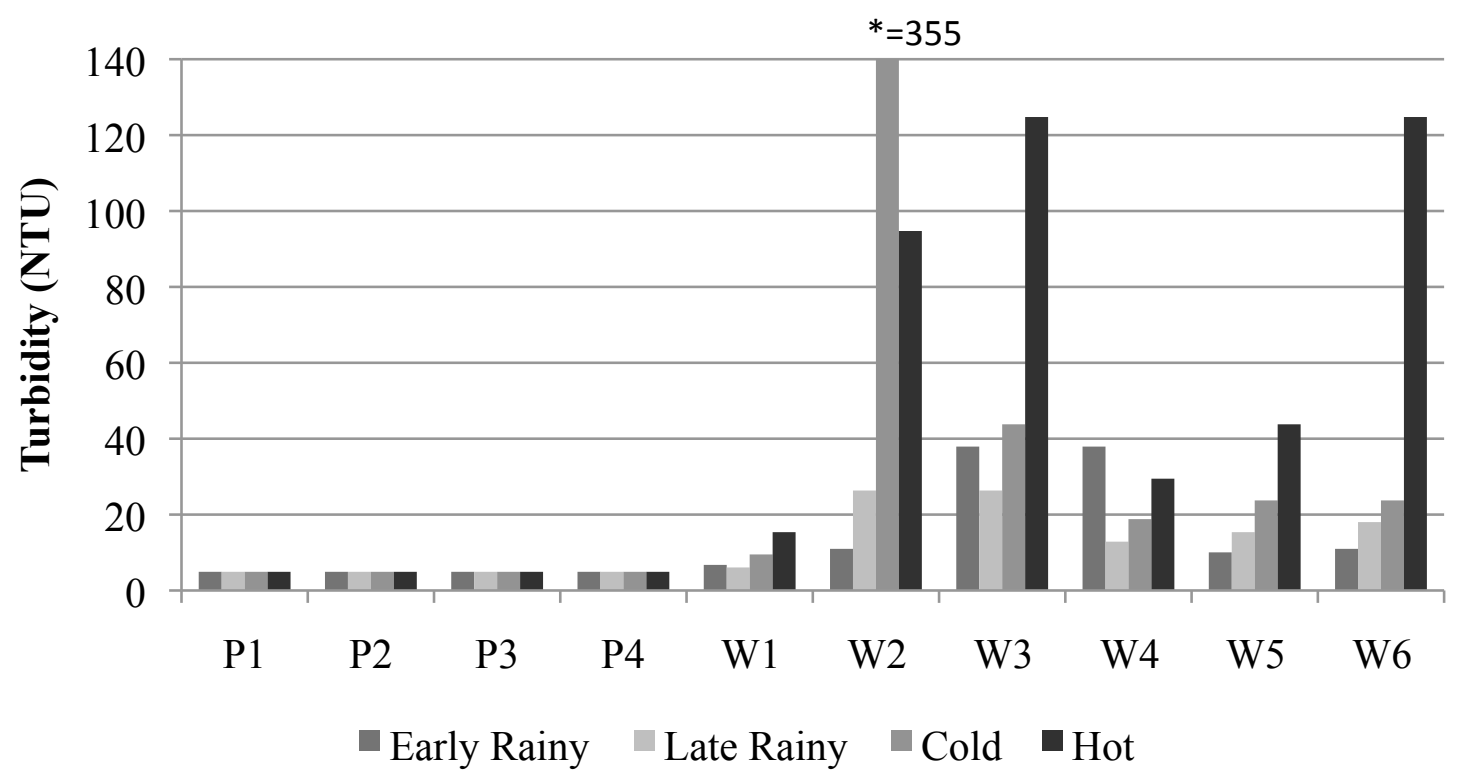

Figure 4.6 Seasonal change in turbidity by source for water from hand pumps $(\mathrm{P})$ and dug wells (W) in Koila Bamana, Mali (2010-2011).

\subsection{Water Collection Patterns}

When this study was set up individual households were associated with a particular water source (e.g., P2) under the assumption that each household would use the same source throughout the year. All households associated with hand pumps consistently used these sources with the exception of one household in cold season and three in hot season. This was even true during late rainy season when hand pump P3 experienced failure. All five households associated with this pump started collecting water from hand pump P4 while P3 was not functioning despite a noticeably farther travel distance from each household (see Figure 4.10).

Water collection patterns changed greatly relative to early rainy season for households that were initially using dug wells (see Figure 4.7). By late rainy season, just over half of all households that had been using a dug well had switched to using a hand pump. This number increased slightly during cold season after I began showing villagers the results 
of previous water testing. During hot season several households switched back to collecting drinking water from dug wells.

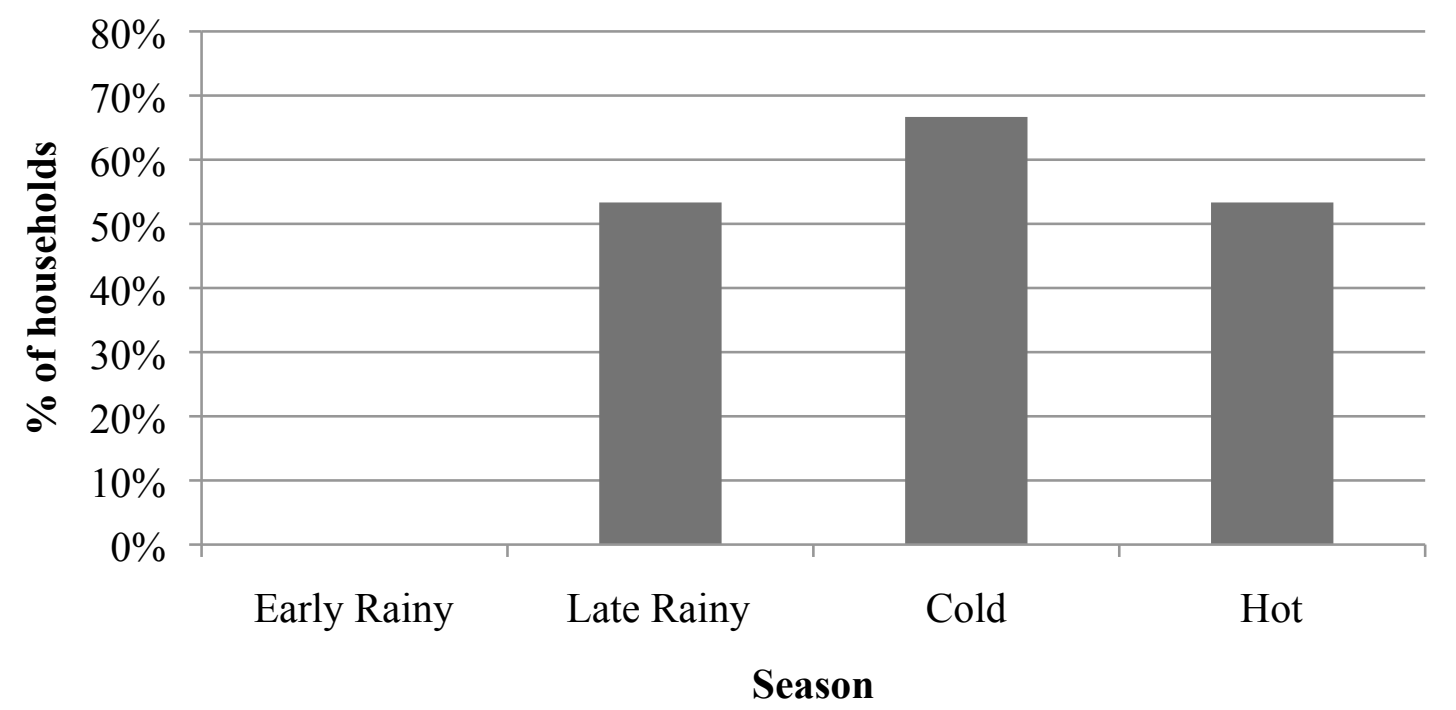

Figure 4.7 Percent of households relative to early rainy season that switched from using a dug well to a hand pump during subsequent seasons in Koila Bamana, Mali (20102011) $(n=30)$.

Table 4.17 shows every household tested during the study and scores the type of source used during each season; 1 if a hand pump was used, and (1) if a dug well was used. The total score indicates each household's water collection tendencies. A total score of "4" means the household used a hand pump during every testing period. Conversely, a score of "(4)" means the household used a dug well during every testing period. A score of " 0 " means the household used dug wells half the time and hand pumps half the time. Figure 4.8 shows this graphically and indicates that over half of all households were using hand pumps for three or more seasons out of the year. 
Table 4.17 Summary of individual household water collection habits; score $=1$ if hand pump used, $=(1)$ if dug well used

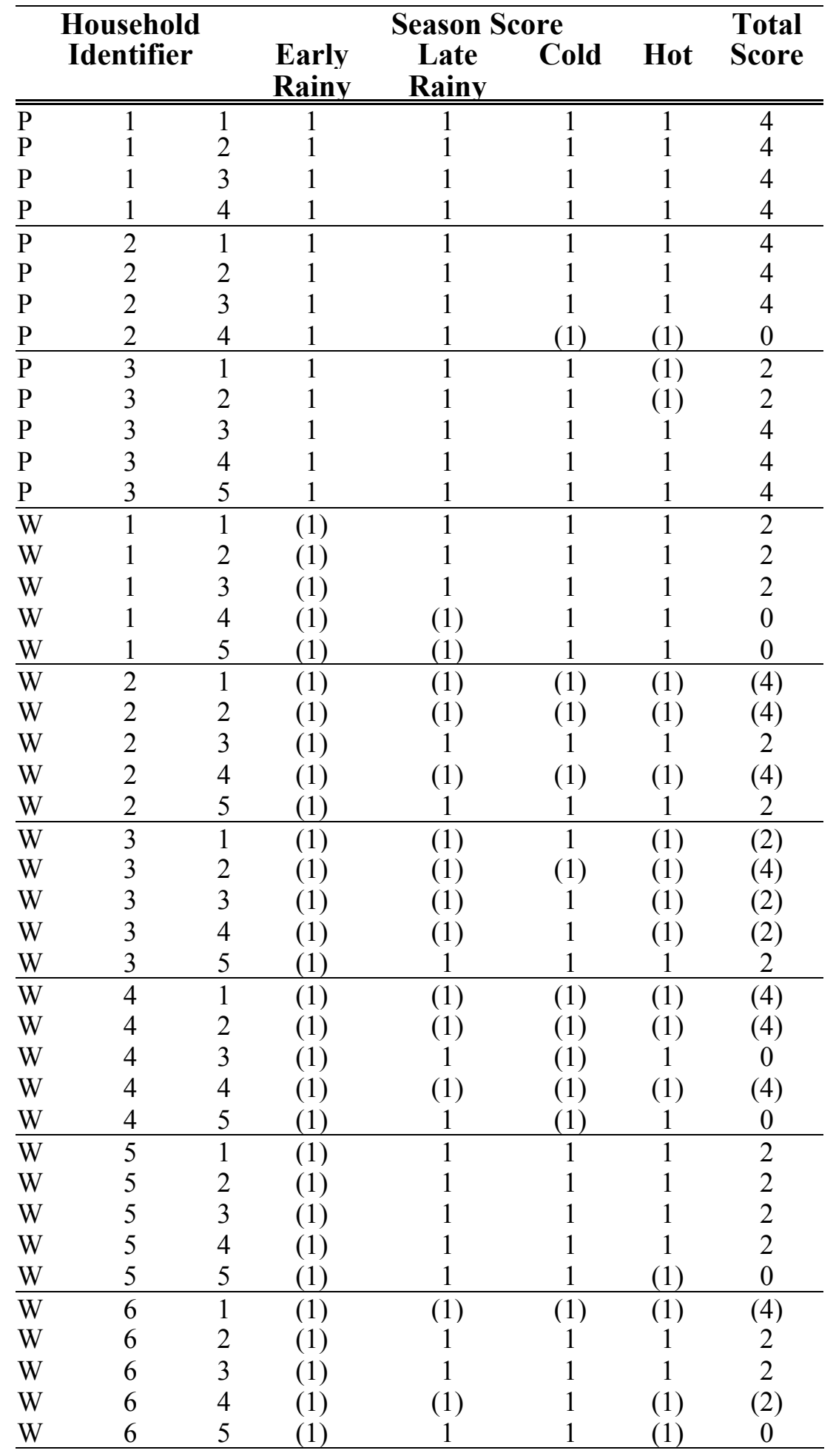




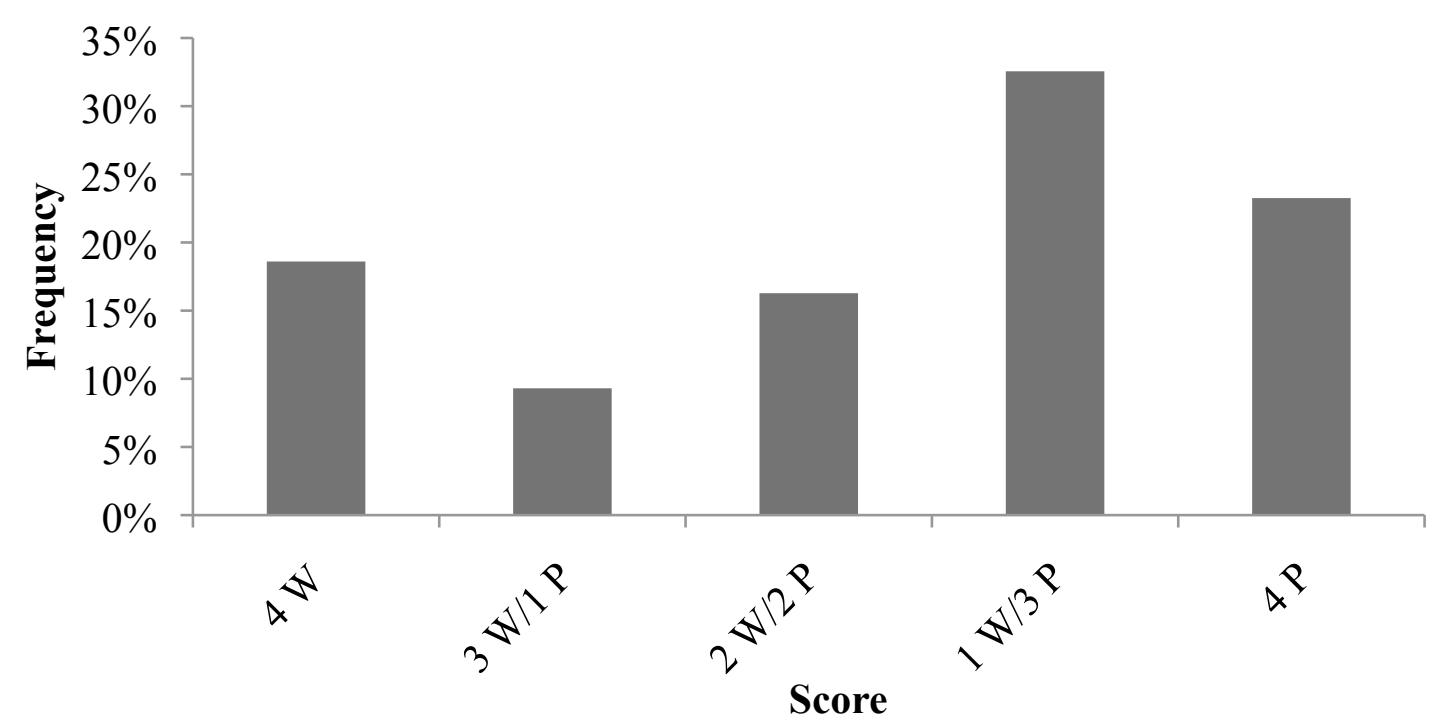

Figure 4.8 Summary of water household collection habits over entire testing period, as assessed seasonally $(\mathrm{n}=172)$. "P" indicates hand pump used, "W" indicates dug well used. Interpretation guide: score of $1 \mathrm{~W} / 3 \mathrm{P}$ indicates that a household used a dug well during one season and a hand pump for three seasons over the entire testing period.

Figure 4.9 shows the water sources used during early rainy season (2010) when all households are collecting water from the source they were assumed to use for the entire year. Colored circles represent households initially associated with dug wells. Colored triangles represent households initially associated with hand pumps. The yellow outlines indicate groups of five households initially associated with each individual source. Figures 4.10 to 4.12 show how household water collection changed spatially during each subsequent season with respect to early rainy season. Of particular note is the fact that hand pump $\mathrm{P} 4$ was not being used by anyone in Koila Bamana for drinking water during early rainy season. However, in subsequent seasons P4 was used by most of the households that had been using dug wells W1, W2, and W5. It is also worth noting that the switch for several households that had been using dug wells required significantly greater travel distances to reach the nearest hand pump. 


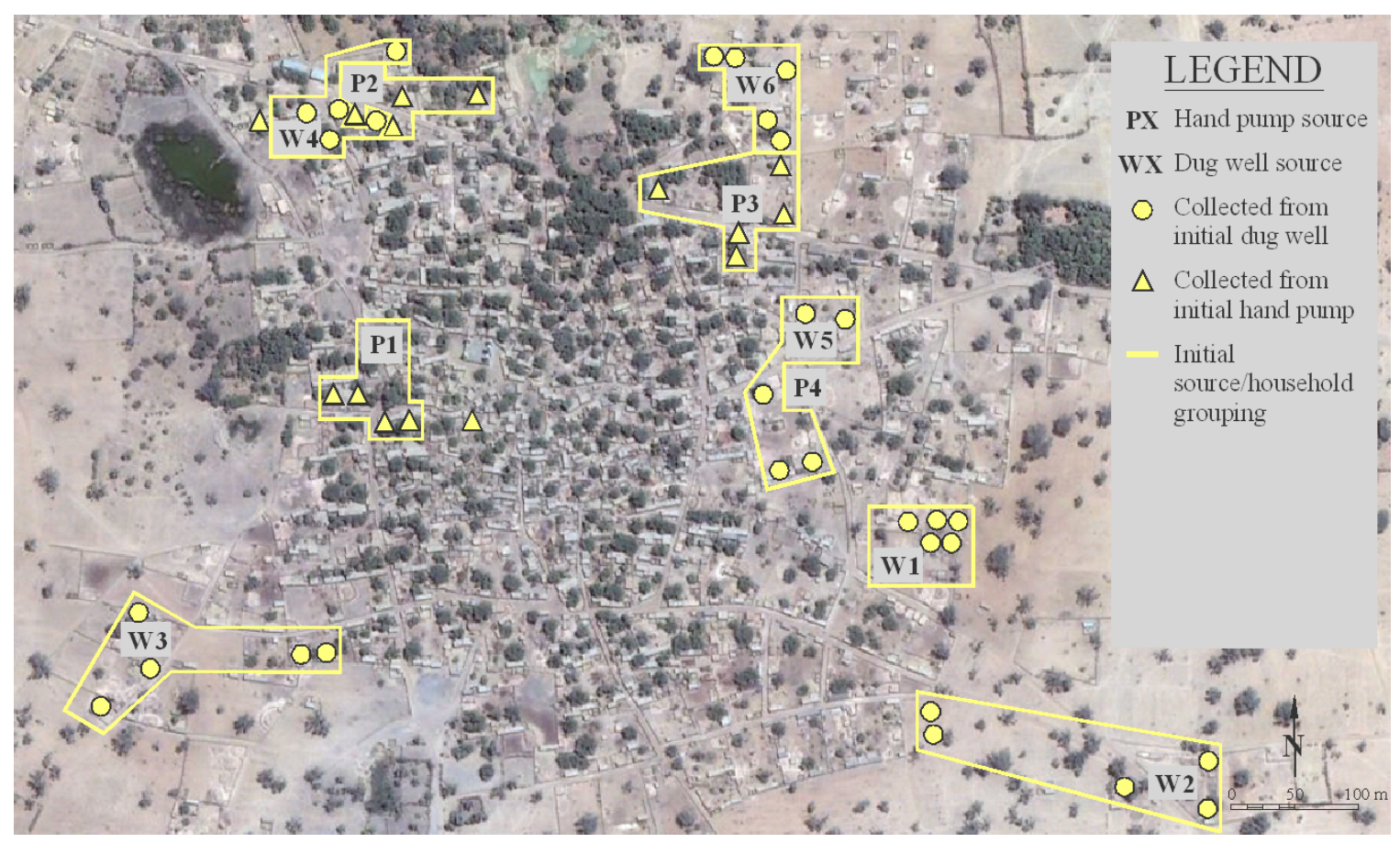

Figure 4.9 Early rainy season (Season \#1) water collection points relative to household locations (circles and triangles), adapted from GeoEye and Google (2011)

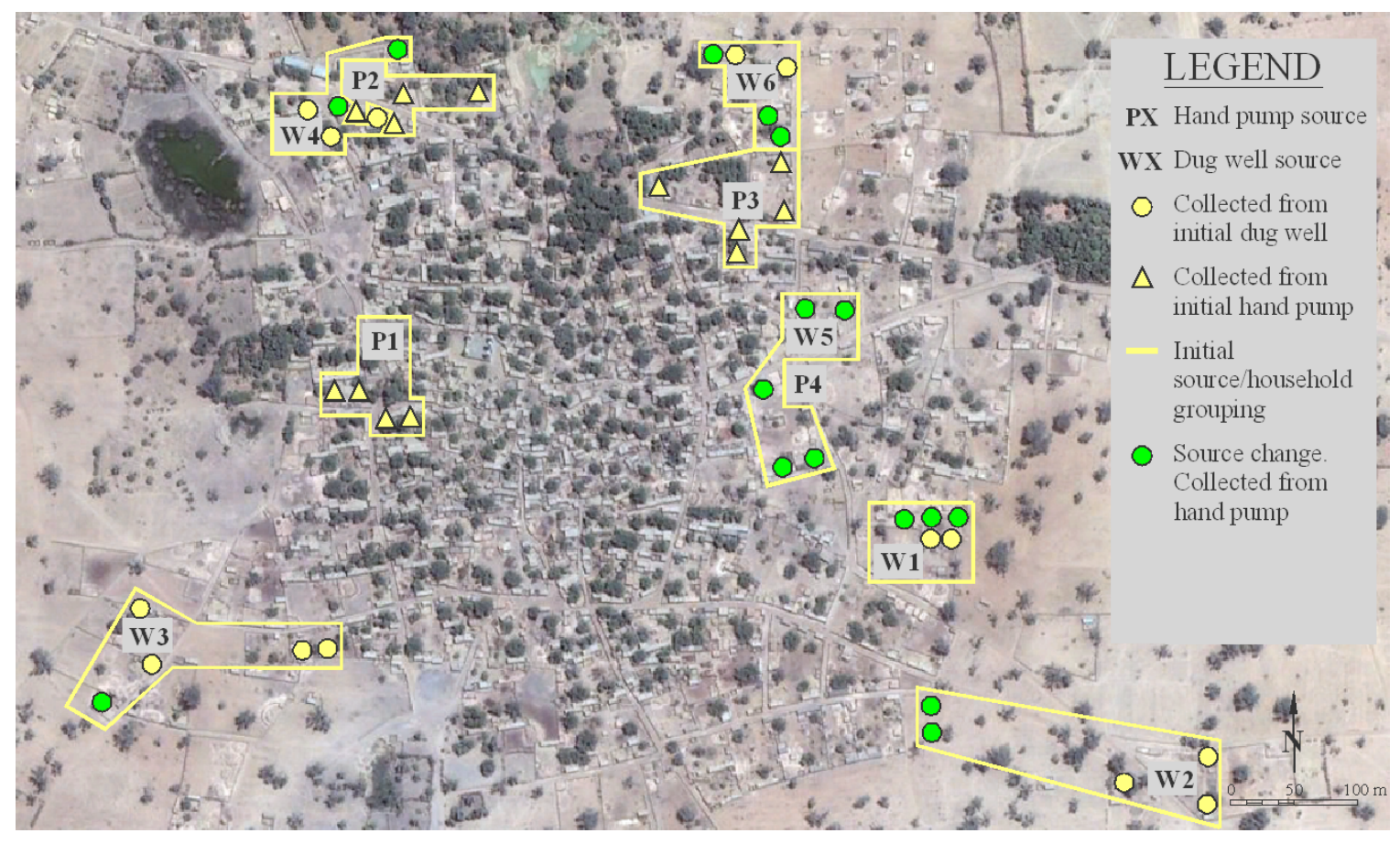

Figure 4.10 Late rainy season (Season \#2) water collection points relative to household locations (circles and triangles), adapted from GeoEye and Google (2011) 


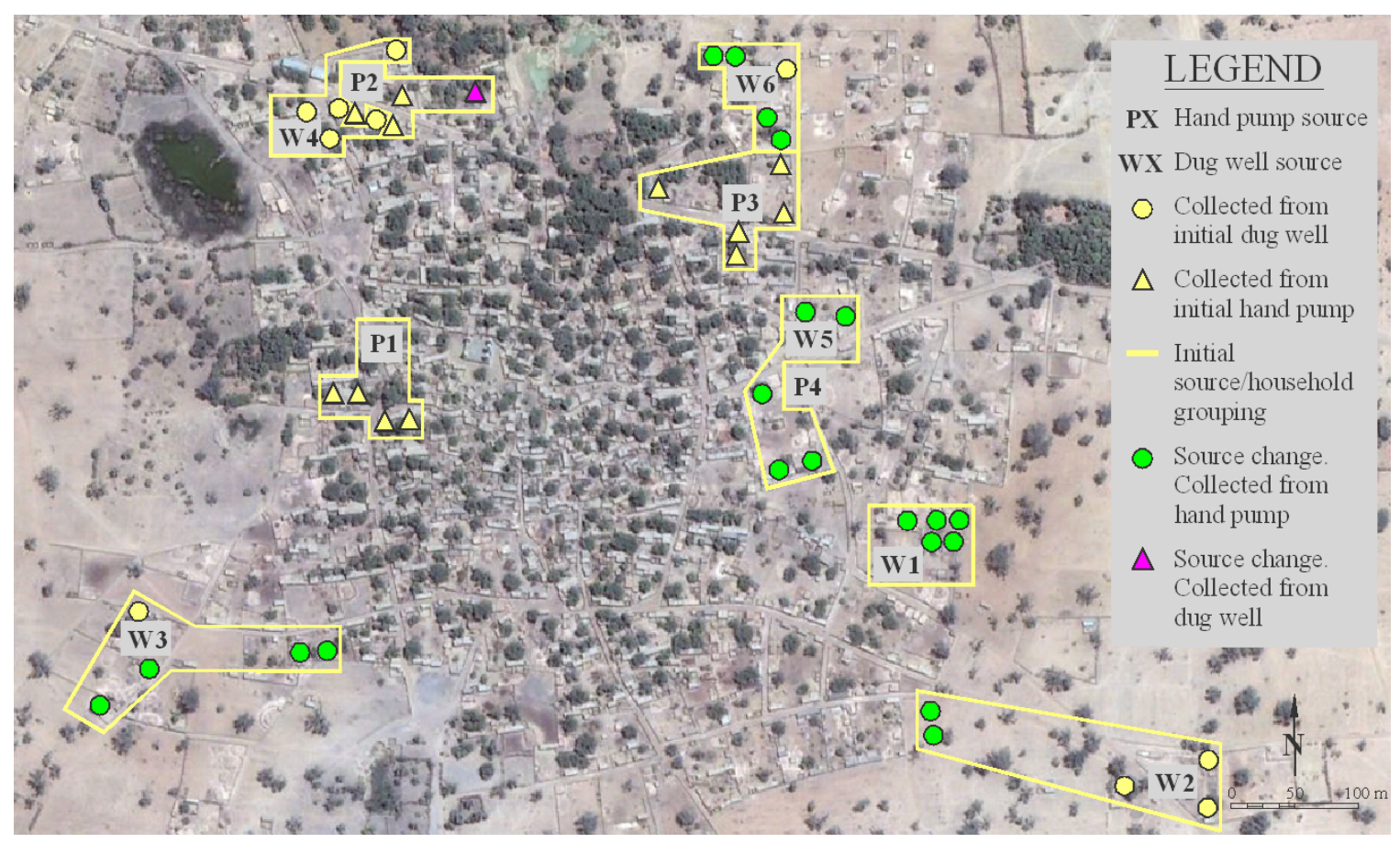

Figure 4.11 Cold season (Season \#3) water collection points relative to household locations (circles and triangles), adapted from GeoEye and Google (2011)

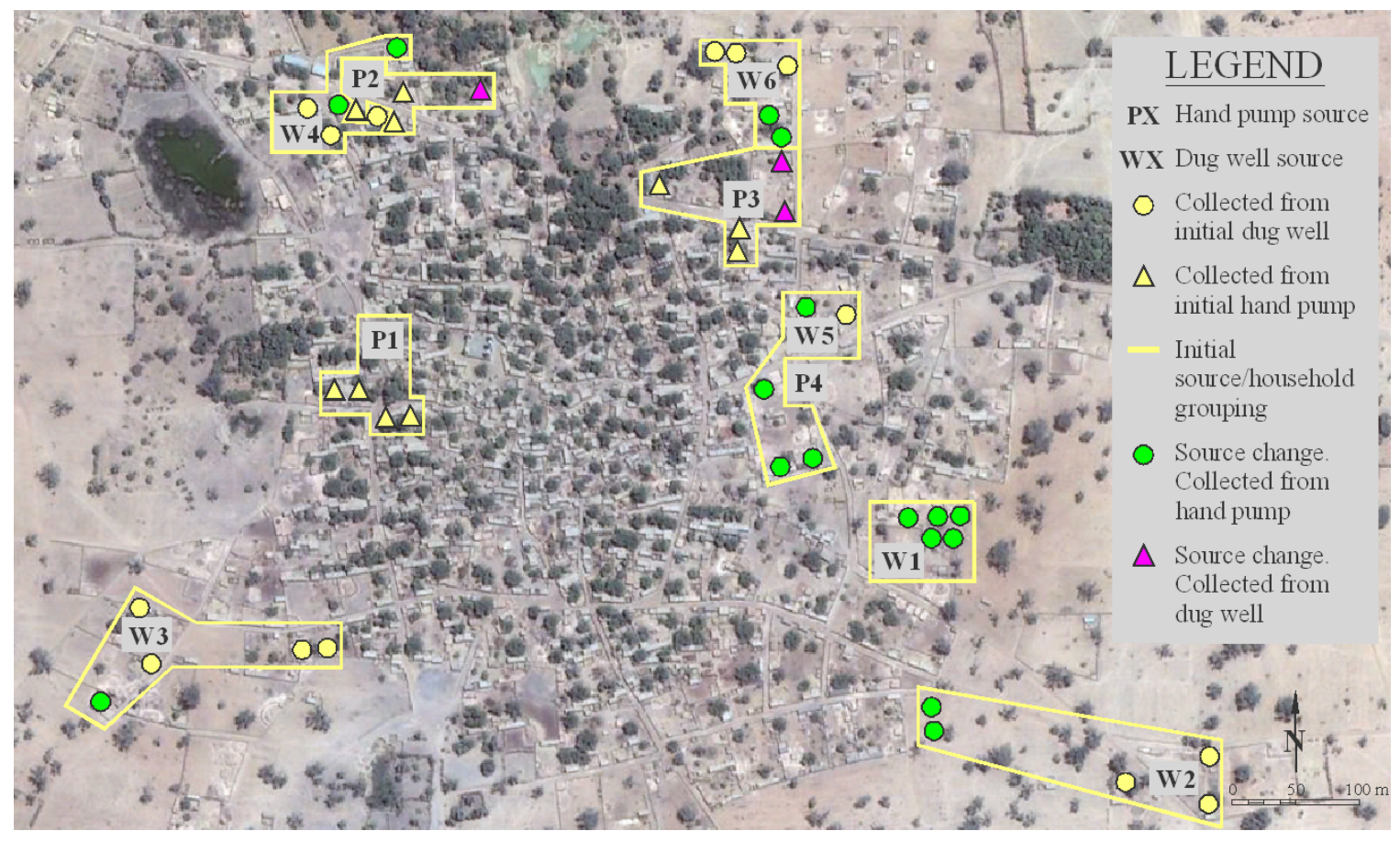

Figure 4.12 Hot season (Season \#4) water collection points relative to household locations (circles and triangles), adapted from GeoEye and Google (2011) 


\section{DISCUSSION}

\subsection{Major Findings}

This work was designed to examine several common drinking water quality parameters including total coliform, E.coli, and turbidity. Results are meant to approximate quality because of limitations of working in resource constrained locations that subsequently prohibit strict adherence to the methods used.

\subsubsection{Bacterial Testing Results at Sources}

Bacterial testing at sources was done to establish a microbial baseline for water quality at the "tap" for different sources monitored. The basis for interpretation comes from the WHO drinking water quality guidelines. The WHO states that E.coli should not be detectable in any $100 \mathrm{~mL}$ sample of drinking water at a source or point-of-use. Additionally, for small water supplies turbidity should not exceed 5 NTUs (WHO 2011). As a comparison, the US EPA drinking water regulations do not allow the presence of any E.coli or total coliforms (USEPA 2009). When applying these guidelines to the source types in Koila Bamana, there is clearly a difference in quality at the "tap". Table 5.1 shows that water coming out of hand pumps is acceptable by WHO guidelines, while water from dug wells is not. The data proves why the JMP considers hand pumps an improved source technology while dug wells are considered unimproved.

Table 5.1 Microbial contamination $(\mathrm{CFU} / \mathrm{mL})$ comparison of water sources in Koila Bamana, Mali for 2010-2011 (annual averages)

\begin{tabular}{ccccc|cc}
\hline Source & $\begin{array}{c}\text { E.coli } \\
(\mathbf{C F U} / \mathbf{m L})\end{array}$ & $\begin{array}{c}\text { WHO } \\
\text { Compliance }\end{array}$ & $\begin{array}{c}\text { Turbidity } \\
\text { (NTU) }\end{array}$ & $\begin{array}{c}\text { WHO } \\
\text { Compliance }\end{array}$ & $\begin{array}{c}\text { T. Coliform U.S. EPA } \\
\text { (CFU/mL) }\end{array}$ & $\begin{array}{c}\text { Compliance } \\
\text { (CFu }\end{array}$ \\
\hline \hline Hand & 0 & Yes & $<5$ & Yes & 0.4 & No \\
Dug Wells & 32 & No & 47 & No & 370 & No \\
\hline
\end{tabular}

\subsubsection{Bacterial Testing Results at Point-of-Use}

Bacterial testing at point-of-use (households) was done to characterize water coming out of the "cup" compared to the "tap" (water source). A simple direct comparison of results at point-of-use (like what was done for sources) does not produce any meaningful information due to a large data set and large range in plate counts. To help facilitate analysis, the data was considered in two categories (plates with total count $\leq 150$ and all plates, regardless of count) based on $3 \mathrm{M}$ 's guideline for a maximum counting range (0- 
$150 \mathrm{CFU} / \mathrm{mL}$ ). The two-category analysis was done in order to avoid determining criteria for removing outliers from the data set. Analysis of plates with a total count $\leq 150$ served as a data set considered free of outliers. This range (total count $0-150 \mathrm{CFU} / \mathrm{mL}$ ) is the basis for specific results used to state variability between sources and seasons. Analysis of all plates, regardless of count, was conducted because the criteria of only considering plates with a total count $\leq 150$ eliminated a large portion of the data from analysis (see Table 4.1). This range (all plates) is meant for more approximate results intended to show pseudo-quantitative differences between sources and seasons.

A direct comparison of total coliform and E.coli results at point-of-use reveal little difference in the averages of plates with a total count $\leq 150$. Expectedly, more pronounced differences are seen when all plates are considered (see Tables 4.10 and 4.11). In order to quantify if the difference between these averages is meaningful, several statistical tests were used to analyze the data. These tests were used to determine if: (1) drinking water quality at point-of-use varies based on source used; and (2) drinking water quality at point-of-use varies by season. Results of these tests show that when considering plates with a total count $\leq 150$ : (1) water quality at point-of-use from each source is consistent throughout the year; and (2) at point-of-use hand pump water is distinguishable (in this case, cleaner) from dug well water for half the year (see Tables 4.12-4.15).

Tables 4.2 and 4.3 indicate that by point-of-use hand pump water most likely has total coliform contamination and may also contain E.coli. Additionally, the statistical analysis indicates that by point-of-use hand pump water is at times indistinguishable from dug well water. This is of note because drinking water from dug wells has been shown to be unacceptable by WHO guidelines (see Table 5.1). The importance of the results is that even if an improved source (in this case hand pump) is doing its job from a design standpoint, it cannot ensure that water quality will be the same once it leaves the tap. Test results for all plates, regardless of count, show high variability which means that on a semi-quantiative basis hand pump water is of better quality than dug well water at pointof-use. The key point is that households associated with both types of sources are likely to have contaminated water.

The most important conclusion is that improved sources such as hand pumps (excluding household connections) can supply water that complies with WHO guidelines, but are incapable of guaranteeing pathogen free water when consumed. It may not be possible to demonstrate that dug well water quality is changing from source to point-of-use (as it is hard to make such water more contaminated), but it is evident with hand pumps (Table 5.2). Based on the average presence of E.coli in water of households using hand pumps, villagers' handling of drinking water between source and point-of-use is causing contamination. It is also important to note that while results in Table 5.2 may seem small 
or negligible for hand pumps, those numbers apply to $1 \mathrm{~mL}$ of water, not $100 \mathrm{~mL}$ as is required by $\mathrm{WHO}$ guidelines.

Table 5.2 Microbial contamination $(\mathrm{CFU} / \mathrm{mL})$ comparison of water at source and pointof-use in Koila Bamana, Mali for 2010-2011 (annual averages)

\begin{tabular}{cccccc}
\hline $\begin{array}{c}\text { Range } \\
\text { CFU/mL }\end{array}$ & $\begin{array}{c}\text { Bacteria } \\
\text { Category }\end{array}$ & \multicolumn{2}{c}{ Hand Pumps } & \multicolumn{2}{c}{ Dug Wells } \\
& & $(\mathbf{n = 2 3})$ & $\begin{array}{c}\text { Point-Of-Use } \\
(\mathbf{n = 1 7 4 )}\end{array}$ & $\begin{array}{c}\text { Source } \\
(\mathbf{n}=\mathbf{3 8})\end{array}$ & $\begin{array}{c}\text { Point-Of-Use } \\
(\mathbf{n}=\mathbf{1 1 7})\end{array}$ \\
\hline \hline$\leq 150$ & Total Coliform & 0.4 & 50 & 370 & 62 \\
& E.coli & 0 & 0.2 & 32 & 1.1 \\
\hline All & Total Coliform & 0.4 & 182 & 370 & 307 \\
& E.coli & 0 & 1.1 & 32 & 11.6 \\
\hline
\end{tabular}

It is also worth noting that this work is not an exhaustive or complete analysis of drinking water quality. Petrifilms ${ }^{\mathrm{TM}}$ test for two kinds of bacteria (total coliform and E.coli), but are not able to test for other kinds of bacteria, viruses or protozoa in drinking water. Additionally, no chemical testing was done, which could be a major concern because of the combination of sandy soil conditions in the area's shallow aquifer, groundwater recharge from flooded rice fields, and the heavy use of agriculture chemicals on the rice fields.

\subsubsection{Bacterial Soil Testing Results at Dug Wells}

Table 4.16 shows that soil collected near the mouth of every dug well had high concentrations of total coliform and E.coli. The large presence of microbes is most likely due to the common practice of keeping animals near wells for watering and in part due to organisms naturally present in soil. Given the common practices such as leaving well bags on the ground, not constructing headwalls at the well mouth, and the lack of a system to remove wash/spillage water, it is clear that contaminated soil is frequently entering wells, resulting in habitual contamination.

\subsubsection{Relationship of Turbidity with Groundwater Depth, Season, and Microbes}

Turbidity was only monitored at sources, not households. Households were excluded because turbidity was not assumed to change greatly from "tap" to "cup". However, I did notice water from several households that typically used hand pumps appeared cloudy on 
occasion, indicating that this assumption was not correct. Additionally, it would have been very difficult to collect the amount of water from every household needed to perform the turbidity test.

According to Figures 4.5 and 4.6, there appears to be a correlation between an increase in turbidity and a decrease in water level in dug wells for part of the year (cold and hot season). This could mean that as the water level in dug wells drops, well bags disturb and suspend more and more sediment at the bottom. However this does not hold true for early rainy season when the water level in dug wells continues to fall, but turbidity is at the annual low. A more likely explanation is that turbidity increases in cold and hot season dust is blowing into the wells. A lack of rain means it is dry and very dusty; so wind is most likely blowing a lot of dust into wells.

There also does not appear to be a strong connection between turbidity and microbial contamination. Turbidity and bacteria levels are higher in water coming from dug wells, but there does not appear to be an obvious correlation between a change in turbidity and a change in amount of bacteria. If anything, temperature could be more of a factor. Microbial levels are noticeably lower in cold season (see Tables 4.4-4.9). This is possibly due to cooler temperatures having an effect on bacteria survival (Thurston, et al. 2001). Also, water is collected less often in cold season because there is less evaporation happening and people may not be drinking as much water. Because of this, storage containers do not empty as fast and do not need to be refilled as often. This means that new bacteria are being introduced less often into storage containers and may not survive as well due to colder temperatures, resulting in a reduced bacterial presence. The opposite is true in hot season when water is collected more frequently and temperatures are more conducive to bacterial survival.

\subsubsection{Water Collection Patterns}

One unintended insight gained from this research was how water collection patterns changed over the course of the year. All households were initially selected on the assumption that they would consistently be collecting water from a single source. The reality, however, was quite different in that collection patterns changed greatly throughout the year. Figure 4.7 shows that after the initial testing period (early rainy season) over half the households that were using a dug well started using a hand pump for the remainder of the year. Table 4.17 and Figure 4.8 indicate that about half of all households consistently stayed with the same source for the entire year (hand pump or dug well), while the other half switched at some point. Figures 4.9-4.12 show that many of the households initially were using dug wells in early rainy season had to go significantly farther to collect water when switching to a hand pump. The fact that roughly half the community did not use the same source throughout the year is important 
to note. As mentioned in Chapter 2, it is common practice to store drinking water in a single container, regardless of the type of source the water was collected from. Since no one in the village treats their water, these collection and storage practices emphasize a critical pathway that likely leads to water contamination at the household after it has been collected from a clean source.

The reasons for collection patterns changing in Koila Bamana come primarily from perceptions of health risks and taste preferences. When people were questioned why they switched from a dug well to a hand pump, the answer was always that water was "dirty" at that time. This description of water being dirty indicates a desire to avoid water that may present health risks if consumed. If a person switched from a hand pump to a dug well the answer was either that water was not dirty anymore or that the person did not have time to get water from a hand pump. This response indicates villager preference for water from dug wells or a lack of the additional time required to collect hand pump water (if the hand pump is far away). In Koila Bamana water collection patterns were based primarily on the perception of risk and then on convenience. Since there are no user fees for gaining access to hand pumps, direct economic factors do not play a role in people's decisions on where they get their water.

\subsection{Villager Challenges}

Villagers clearly play a role in water quality in Koila Bamana. While no single pathway can be identified as a primary cause for contamination, it is clear that handling of water during collection, storage, and source use can cause contamination. This can be attributed to a poor understanding of germ theory and hygiene. There is no public or personal perception that certain behaviors can cause drinking water to become a risk to personal health. There is also poor understanding about when something becomes contaminated, so even if steps are taken to avoid becoming sick, they are often misguided. The primary example of this was the large number of households that switched to hand pumps after early rainy season (see Figure 4.7). Villagers believed that by simply switching to what they understood to be a clean source they were eliminating a health risk. However, they were unaware that human interactions with water could also create problems leading to health risks.

It is important to note the taste preferences for the two sources. The majority opinion among villagers was that dug well water tastes better than hand pump water, yet over half of dug well users switched to hand pumps when they understood dug well water to be a danger to their health. It is also interesting that over time several households switched from hand pumps back to dug wells, indicating that some people only understand dug wells to be a danger periodically. The underlying message is that villagers were willing to sacrifice aesthetics in order to eliminate perceived health risks. Households that 
continually used dug wells demonstrated that their perceived risk was not great enough for them to switch to hand pumps.

Showing results of Petrifilm ${ }^{\mathrm{TM}}$ tests had a significant impact on villagers' understanding of local water quality. Villagers were shocked to see the amount of bacteria present in the water they were drinking. They clearly understood that something bad was in their water and that they needed to make changes to eliminate the problem. However, villagers were not able to make the connection between collecting water that was pathogen-free (from hand pumps) and the fact that they were contaminating their own drinking water before they consumed it. They thought the problem of contamination only existed at the source (dug wells) and did not extend to the household. Many villagers asked me to help them treat their wells - a procedure I had not introduced before. People were using what they understood about the problem to seek a solution; if water was contaminated, they needed to start going to a pump or treat their well with bleach.

\subsection{Malian Challenges}

Malian government health officials and development agencies need to change existing policies that promote treating dug wells with bleach and instead encourage Malian citizens to disinfect at the point of storage. Dug well contamination is not difficult to explain based on common practices involving construction, use, and nearby daily activities. Bacterial soil testing (see Table 4.16) suggests that soil entering dug wells from well bags, wind, or wash water are likely sources of contamination. Dug well proximity to latrines and the common practice of digging latrine pits into the water table means there is a possibility of groundwater already being contaminated before it enters a dug well.

Even if a dug well is treated with bleach, it will most likely be re-contaminated as soon as the free chlorine is used up. Dug wells, therefore, need to be treated at short, regular intervals to ensure absence of pathogens. Consequently, dug well treatment is more expensive than daily point-of-use treatment because more chlorine is needed to treat all the water in the dug well versus only water extracted for consumption. Officials that support dug well treatment promote this strategy because they say individuals will not treat drinking water in their homes, which is true at present. However, the unwillingness to adopt household treatment has everything to do with an individual's economic understanding of the situation. Villagers in Koila Bamana thought that household treatment was too expensive, but were willing to treat their dug wells. They did not understand that to achieve the same level of quality, household treatment would be much cheaper and simpler to dose. 


\subsection{Development Challenges}

The situation in Koila Bamana is not unique. These same water quality issues are experienced throughout the world (Trevett, et al. 2005). Because of the low level of education and lack of understanding of good sanitary behaviors, there is a need for a holistic approach to solving the drinking water needs of the poor (The MDG Centre 2011).

In years past, the traditional approach to development was topic specific. As Figure 5.1 points out, interventions typically focused on individual project areas. "Tunnel vision" was prevalent in the development community, and organizations simply did not look beyond the particular problem they had identified. There was not a general recognition that many of the problems common in developing communities impact each other, meaning a systems approach to solutions is needed.

Additionally, entities from outside a community (government or development agency) would try to make improvements to help people, but few had lasting success. Typically the strategy was simply to install some kind of physical infrastructure (e.g. borehole and hand pump). There was not a sufficient level of partnership established with the community to create a sense of project ownership for the community, which is essential for success. Long-term outreach targeting education and behavior change were also not important elements to a project (Gleitsmann, et al. 2007).

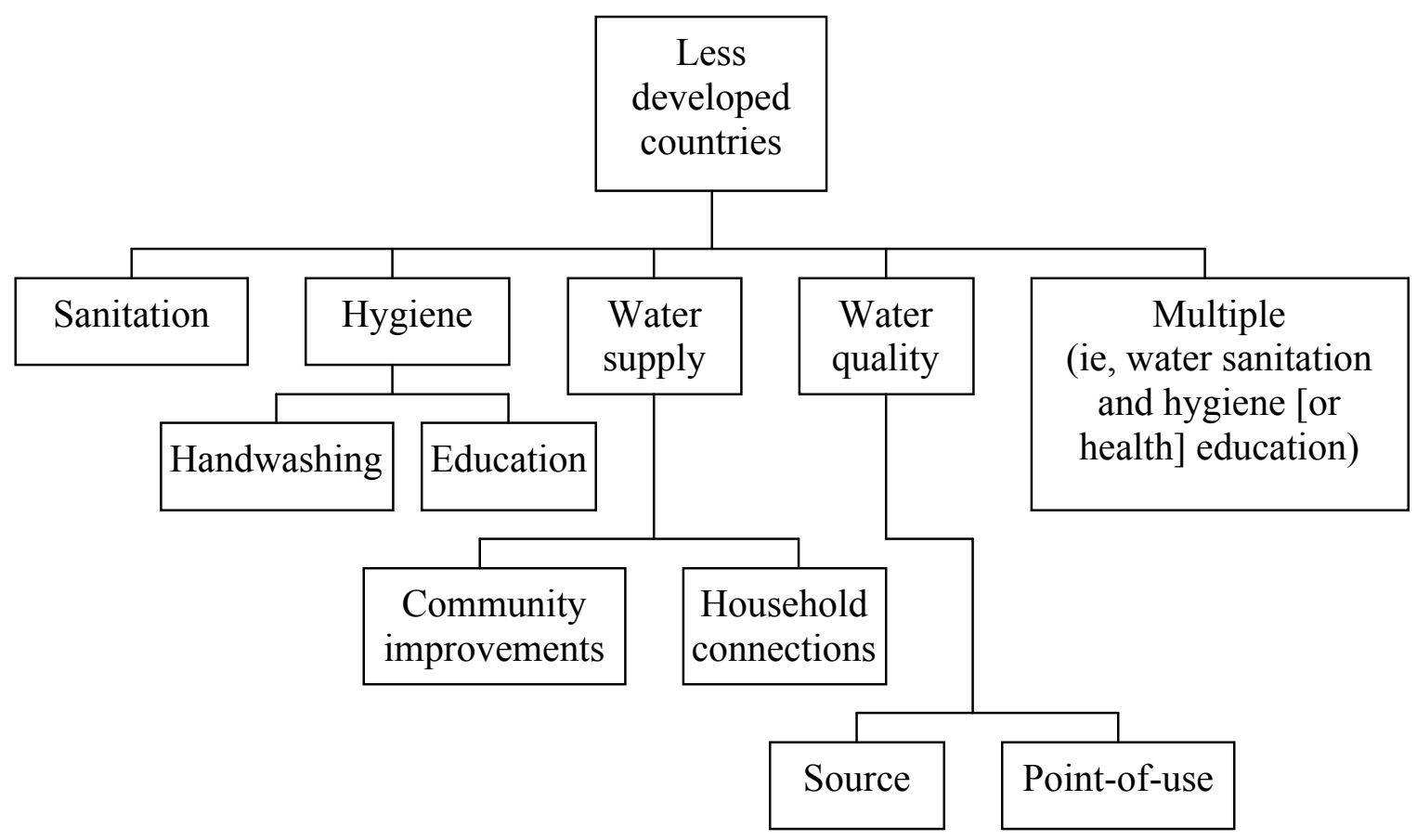

Figure 5.1 Intervention flow chart, adapted from (Fewtrell, Kaufmann et al. 2005) 
Tools, knowledge, and capacity must be integrated for successful solutions. The development community has only recently begun using this approach with water and sanitation needs. In Koila Bamana the emphasis has been on providing infrastructure (access to water), but there has been no "instruction manual" or "tech support" provided by the entity that made the improvements. Communities often do not know how to maintain their infrastructure or what will be required financially to do so. Additionally, communities do not understand that the benefits of an improved system rely upon their behavior as well. The safe water benefits of an improved drinking water source are clearly lost if the community has poor hygiene behavior (Trevett, et al. 2005). More needs to be done to promote point-of-use treatment, but solutions at the household level often require long-term committed partnerships; human habits change slowly. If residual disinfection is a standard component of drinking water supply in the developed world, it should become a standard component of drinking water projects in development projects as well.

The collective results of health studies done in developing countries over the past 40 years have shown that single interventions focusing on water supply and source treatment have highly variable success rates and are not effective at reducing common diseases such as diarrhea (Fewtrell et al. 2005). However, water quality interventions at the household level have been one of the most effective single interventions (Figure 5.2). Also, strategies involving multiple interventions have proven to be fairly effective and have had the least amount of variability 


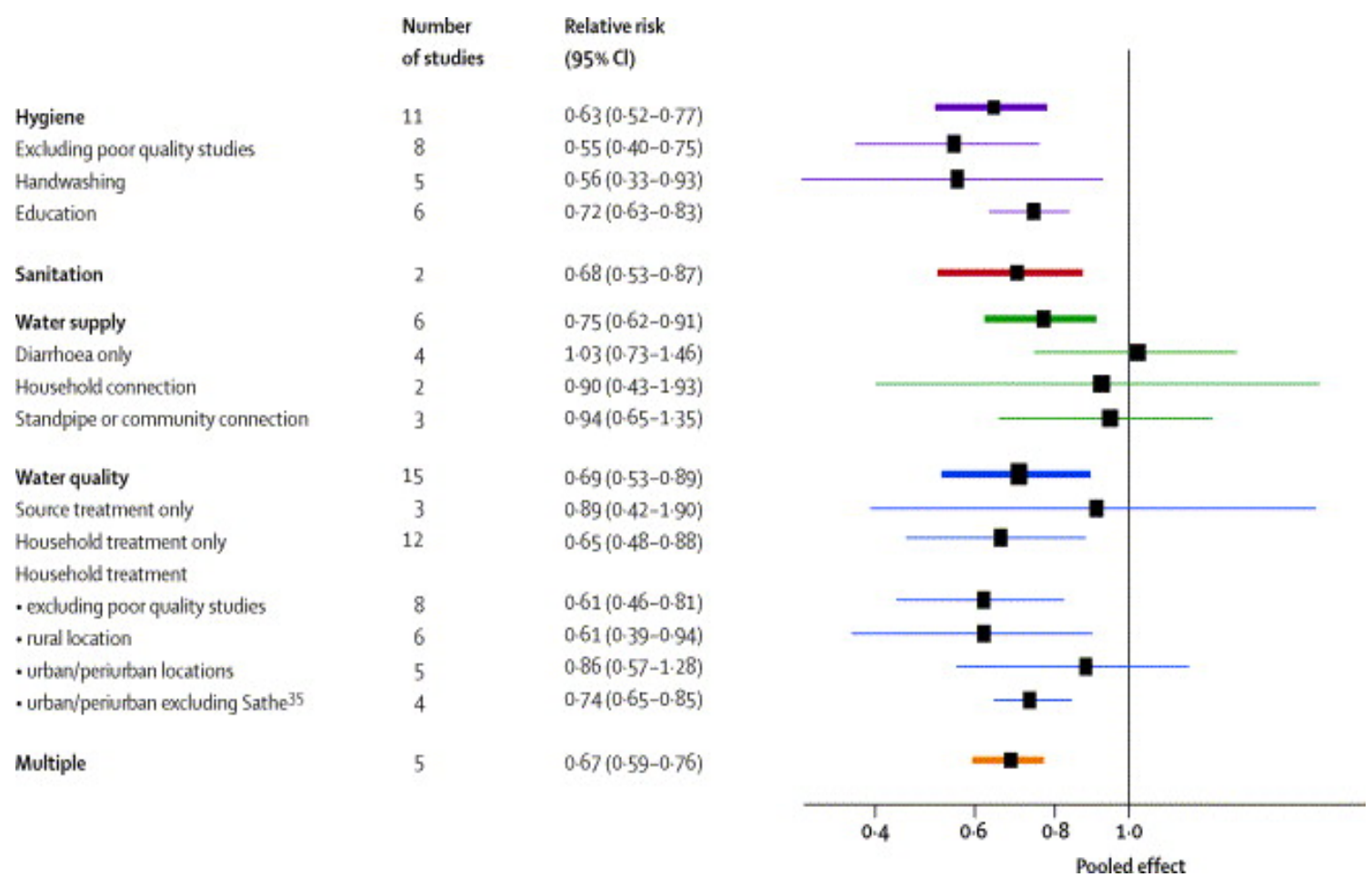

Figure 5.2 Historical effectiveness of various interventions to prevent diarrhea (from Fewtrell, et al. 2005)

\section{CONCLUSIONS AND RECOMMENDATIONS}

\subsection{Conclusions}

To summarize, the general objective of this project was to determine if promoting interventions at the source (improved vs. unimproved source) is a good way to ensure good water quality, or if other strategies might be needed to ensure safe water is being consumed at point-of-use. To resolve this, the following specific objectives were investigated to determine:

1) If there is a difference in water quality between different source technologies in village (hand pumps and hand-dug wells),

2) If there is water quality degradation at point of consumption (point-of-use) compared to each improved water source observed,

3) If drinking water quality at point-of-use varies based on source used, and

4) If drinking water quality at point-of-use varies based on season. 
Several major findings can be drawn from this work in Koila Bamana, Mali. The first is that improved sources such as borehole hand pumps are an effective means for providing safe drinking water (pathogen free, in this community) while dug wells are not (Objective 1). The second is that the presence of an improved source is not a sufficient solution to ensure that a target population is consuming safe drinking water (Objective 2). Thirdly, at point-of-use hand pump water is only distinguishable from dug well during half the year (Objectives 3 and 4). The fourth is that villagers' water collection patterns changed throughout the year based on understanding of what sources were safe and good tasting. Lastly, villagers' lack of germ theory knowledge contributes to poor water quality at point-of-use and is a major public health challenge. In order to ensure communities are consuming good quality/safe drinking water, more needs to be done than only providing access to improved sources. Health and water hygiene education and household level water treatment programs need to be an integral part of any project aiming to improve this community's health.

\subsection{Future Work}

Future work should be done to develop a program that incorporates an effective visual means of testing water quality and an education program that encourages people to treat their drinking water when needed. The reason to emphasize a visual means of testing is so that people with no formal education are able to understand water contamination. For many, seeing is believing.

Additionally, more household-level evidence needs to be collected in order to convince the WHO to incorporate water quality at point-of-use into its definition of sustainable access to safe drinking water. There is a need to develop standard analytical methods and tools for water quality testing in communities with extreme resource constraints, along with development programs specifically charged with monitoring the quality of drinking water from development projects around the world, especially in small, rural communities.

\subsection{Recommendations}

Understandably, there is a need for changes to be made in development strategies adopted by aid agencies and governments regarding access to safe water. In the last few years this need has been acknowledged and new approaches are being sought. The WHO acknowledges that while the MDG drinking water target is focused on improved sources for increased access, it does not pay particular attention to water quality (Clasen 2008). Some are now focusing on holistic strategies to tackle development issues (The MDG Centre 2011). Additionally, methods such as the rapid assessment of drinking water 
quality (RADWQ) are being developed in order to monitor the quality of drinking water coming out of improved sources (JMP 2010).

One limiting factor to monitoring drinking water quality on a global scale is the current absence of a cost effective and effective analytical field method. Petrifilms ${ }^{\mathrm{TM}}$ could be a good option to this dilemma. While Petrifilms ${ }^{\mathrm{TM}}$ do not provide a full microbial representation of water quality and do not test for chemical constituents, they are nonetheless helpful, inexpensive, easy to transport, and readily understood because they provide a visual representation of the microbial content of water. This was clearly the case with villagers in Koila Bamana; most are illiterate and do not understand germ theory, but were easily able to make the connection between what they saw on a Petrifilm ${ }^{\mathrm{TM}}$ and what they were drinking. Petrifilms ${ }^{\mathrm{TM}}$ would therefore not only be good for a quick microbial assessment of drinking water, but could also serve as a teaching tool to help increase people's understanding of drinking water quality and safe water.

The development community needs to redesign its standard approach to providing communities with sustainable access to safe drinking water. In developed communities the preferred technology is a piped distribution system with indoor household taps, but this is also the most expensive. Until such a solution can be made a reality for everyone more cost effective solutions need to be employed; water access in the form of communal taps are a likely intermediate solution. However, communal taps also carry additional risks of contamination compared to a system with household taps. As such, water treatment must be part of new water access points intended for human consumption. The myriad different waterborne pathogens, and removal requirements associated with each, suggests that an effective system for communities that can only afford to have communal water collection points would be to adopt a two-tiered approach. Part one would be to provide an improved source, such as a borehole with hand pump, to preserve source water quality and minimize contamination. Part two would be chemical disinfection at point-of-use, to eliminate many common waterborne pathogens introduced from collection, transport, storage, and use. Sustainable access to safe drinking water needs to include increased availability of consistent water supplies and a means of ensuring that water is safe up to the time it is consumed (Nath, et al. 2006). 


\section{REFERENCES}

3M (2008). "Petrifilm ${ }^{\mathrm{TM}}$ E.coli/Coliform Count Plate Interpretatin Guide." Retrieved 07/16/11, from http://tinyurl.com/6jeka5v.

3M (2011). "3M $\mathrm{M}^{\mathrm{TM}}$ Petrifilm ${ }^{\mathrm{TM}}$ E.coli/Coliform Count Plates." Retrieved 07/16/11, from http://tinyurl.com/6ba2uc2.

A. Dufour, M. Snozzi, et al. (2003). Assessing microbial safety of drinking water: Improving approaches and methods. London, IWA Publishing.

C.I.A (2009). "The World Factbook 2009." Retrieved 7/16/2011, from https:/www.cia.gov/library/publications/the-world-factbook/geos/ml.html.

Carter, R., S. Tyrrel, et al. (1999). "Assumptions and realities in water and sanitation programmes." Waterlines 18: 2-5.

Chung, P. , S. Trottier, and S. Murcott. (2011). Comparison and verification of four fieldbased microbiological tests: H2S test, Easygel ${ }^{\circledR}$, Colilert $\AA$, PetrifilmTM. Journal of Water, Sanitation and Hygiene for Development. 1(1):68-85.

Clasen, T., Bastable, A., (2003). "Faecal contamination of drinking water during collection and household storage: the need to extend protection tothe point of use." Journal of Water and Health 3(1): 109-115

Clasen, T. and P. Edmondson (2006). "Sodium dichloroisocyanurate (NaDCC) tablets as an alternative to sodium hypochlorite for the routine treatment of drinking water at the household level." International Journal of Hygiene and Environmental Health 209(2): 173-181.

Clasen, T. F. (2008). Scaling Up Household Water Treatment: Looking Back, Seeing Forward. Geneva, WHO.

Colin, J. (1999). "VLOM for Rural Water Supply: Lessons from Experience." Water and Environmental Health at London and Loughborough 162(March 1999): 1-21.

Davis, J. and R. Lambert (2002). Engineering in emergencies: a practical guide for relief workers, ITDG.

Fewtrell, L., J. Bartram, et al. (2001). Water quality: guidelines, standards, and health : assessment of risk and risk management for water-related infectious disease, IWA Pub.

Fewtrell, L., R. B. Kaufmann, et al. (2005). "Water, sanitation, and hygiene interventions to reduce diarrhoea in less developed countries: a systematic review and meta-analysis." The Lancet Infectious Diseases 5(1): 42-52. 
GeoEye and Google (2011). Google Earth image of Koila Bamana (13.658435,5.751368), www.google.com/earth.

Gleitsmann, B. A., M. M. Kroma, et al. (2007). "Analysis of a rural water supply project in three communities in Mali: Participation and sustainability." Natural Resources Forum 31(2): 142-150.

Gundry, S. et al. (2004). "A systematic review of the health outcomes related to household water quality in developing countries." Journal of Water and Health 1(2): 1-13

Humphrey, M., Ed. (2006). Hippo Handbook. Bamako, Peace Corps.

Jensen, P., et al. (2002). "Domestic transmission routes of pathogens: the problem of inhouse contamination of drinking water during storage in developing countries" Tropical Medicine and International Health 7(7): 604-609

JMP (2010). "WHO / UNICEF Joint Monitoring Programme (JMP) for Water Supply and Sanitation." Retrieved 7-16-2011, from http://www.wssinfo.org/definitionsmethods/watsan-categories/.

Math \& Science Center (2005). "Make a Turbidity Tube." Retrieved 7-18-2011, from http://www.mathinscience.info/public/0\%20How\%20to/oceanography_studies/turbidtube .pdf.

Ministere des Mines de 1'Energie et de 1'Eau (2004). Etat des lieux des Politiques et Stratégies du secteur de l'eau - Perspectives de Développement. Consultation sectorielle sur L'ACCES A L'EAU POTABLE. Bamako, Ministere des Mines de l'Energie et de l'Eau.

Myre, E. and R. Shaw (2006). The Turbidity Tube: Simple and Accurate Measurement of Turbidity in the Field, Department of Civil and Environmental Engineering, Michigan Technological Univesity.

Nath, K.J., et al. (2006). Household water storage, handling and point-of-use treatment. Geneva, Switzerland, International Scientific Forum on Home Hygiene, IFH

Parker, R. (1997). Mali: Rural Water Supply Project. E. Campbell-Pagé, World Bank.

Payment, P., M. Waite, et al. (2003). Assessing microbial safety of drinking water: Improving approaches and methods, WHO \& OECD.

Porkess, R. (2006). Collins Web-Linked Dictionary of Statistics. Glasgow, Harper Collins Publishers. 
Reynolds, J. M. (1992). Handpumps: Toward a sustainable technology : research and development during the water supply and sanitation decade, UNDP-World Bank Water and Sanitation Program (Washington, DC)

S.K. Industries (2008). "India Mark 2 Handpump." Retrieved 7-16-2011, from http://skipumps.com/mark2 details.htm.

Sobsey, M.D., et al. (2003). "Chlorination and safe storage of household drinking water in developing countries to reduce waterborne disease." Water Science and Technology 47(3): $221-228$

The MDG Centre (2011). "Water and Sanitation." Retrieved 7-19-2011, from http://mdg.ei.columbia.edu/east/?id=programmes_water.

Thurston, J. A., K. E. Foster, et al. (2001). "Fate of indicator microorganisms, giardia and cryptosporidium in subsurface flow constructed wetlands." Water Research 35(6): 15471551.

Traore, H. (2011). Interview regarding Peace Corps-Mali's Water/San development strategies. M. Seib. Bamako.

Trevett, A., R. C. Carter, et al. (2004). "Water quality deterioration: a study of household drinking water quality in rural Honduras." International Journal of Environmental Health Research 14(4): 273-278.

Trevett, A. F., R. C. Carter, et al. (2005). "The importance of domestic water quality management in the context of faecal-oral disease transmission." Journal of Water and Health 3(3): 259-270.

UN (2010). The Millennium Development Goals Report 2010. New York, United Nations.

UNESCO (2011). "The Millennium Development Goals and Water." Retrieved 7-18-11, from http://www.unesco.org/water/wwap/facts figures/mdgs.shtml.

UNICEF (1993). India Mark III (VLOM) deepwell handpump : installation and maintenance manual. New Delhi, India, UNICEF.

USEPA (2009). "National Primary Drinking Water Regulations." Retrieved 7-18-2011, from www.epa.gov.

Vail, J. H., R. Morgan, et al. (2003). "Enumeration of waterborne Escherichia coli with petrifilm plates: Comparison to standard methods." Journal of Environmental Quality 32(1): 369-373. 
WHO (2011). Guidelines for drinking-water quality, fourth edition, WHO.

WHO/UNICEF (2010). Progress on sanitation and drinking-water 2010 update, WHO.

Wordtravels (2011). "Mali Maps." Retrieved 7-20-11, from http://www.wordtravels.com/Travelguide/Countries/Mali/Map.

World Meteorological Organization (2011). "Mali Climatalogical Information." Retrieved 7/25/2011, from http://worldweather.wmo.int/034/c00132.htm.

Wright, J., et al. (2004). "Household drinking water in developing countries: a systematic review of microbiological contamination between source and point-of-use." Tropical Medicine and International Health 9(1): 106-117. 


\section{APPENDIX A}

Images of sources used for testing

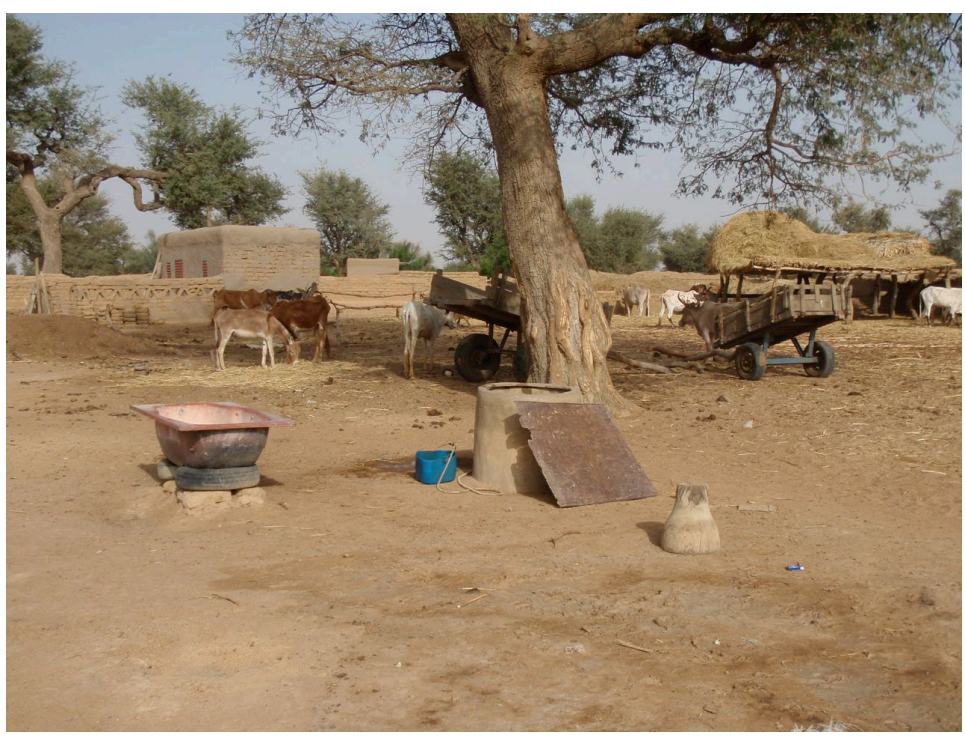

Figure A.1 Dug Well W1

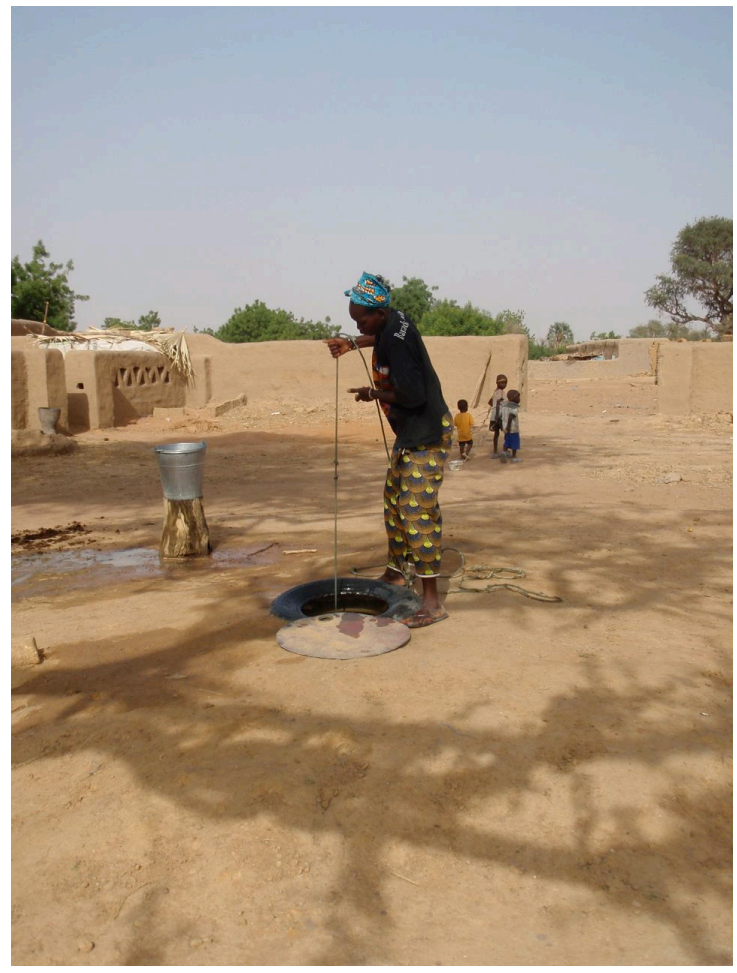

Figure A.2 Dug Well W3 


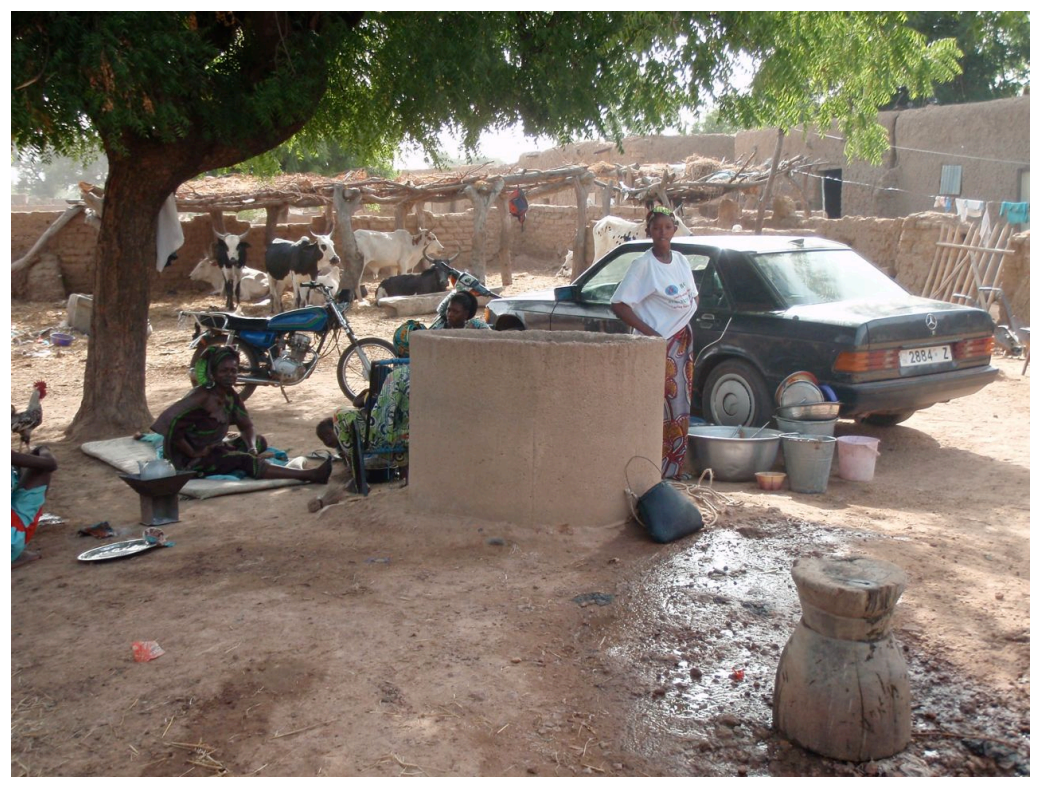

Figure A.3 Dug Well W4

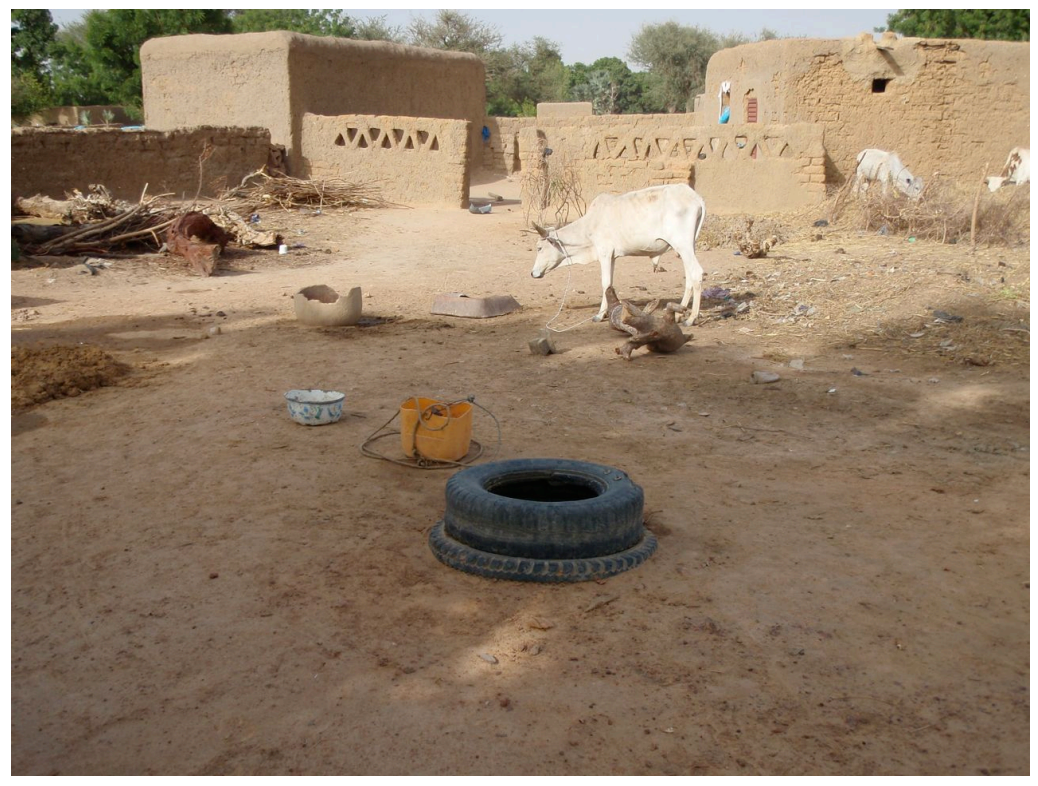

Figure A.4 Dug Well W5 


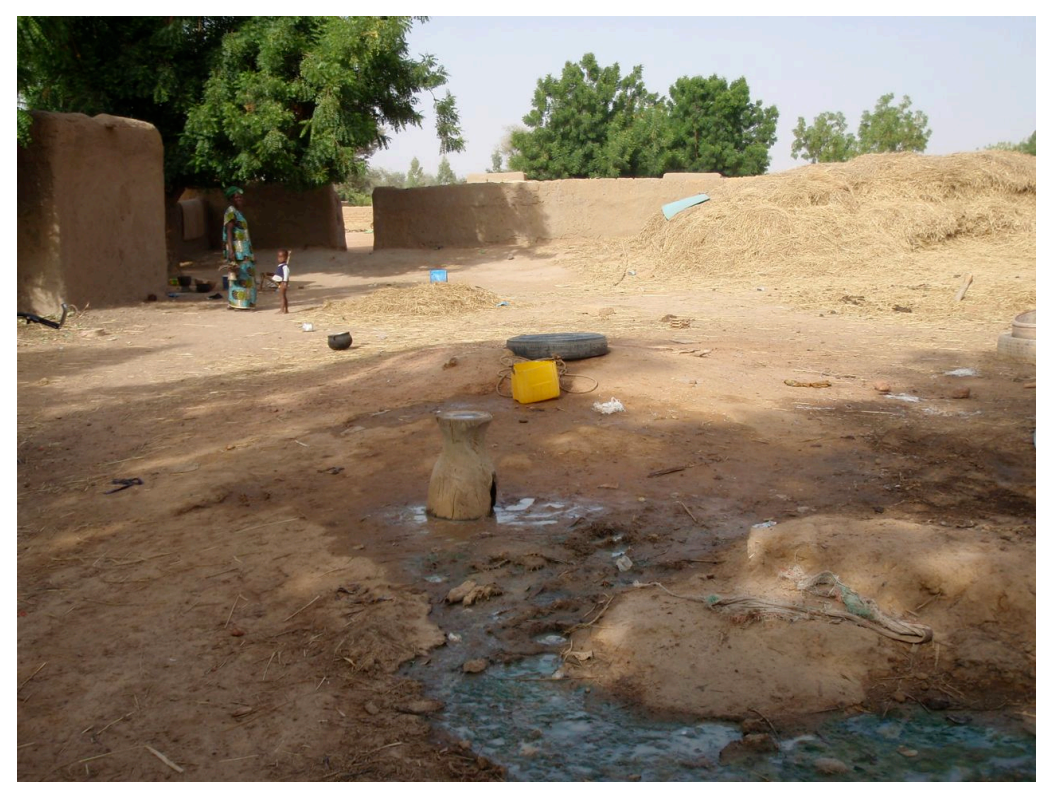

Figure A.5 Dug Well W6

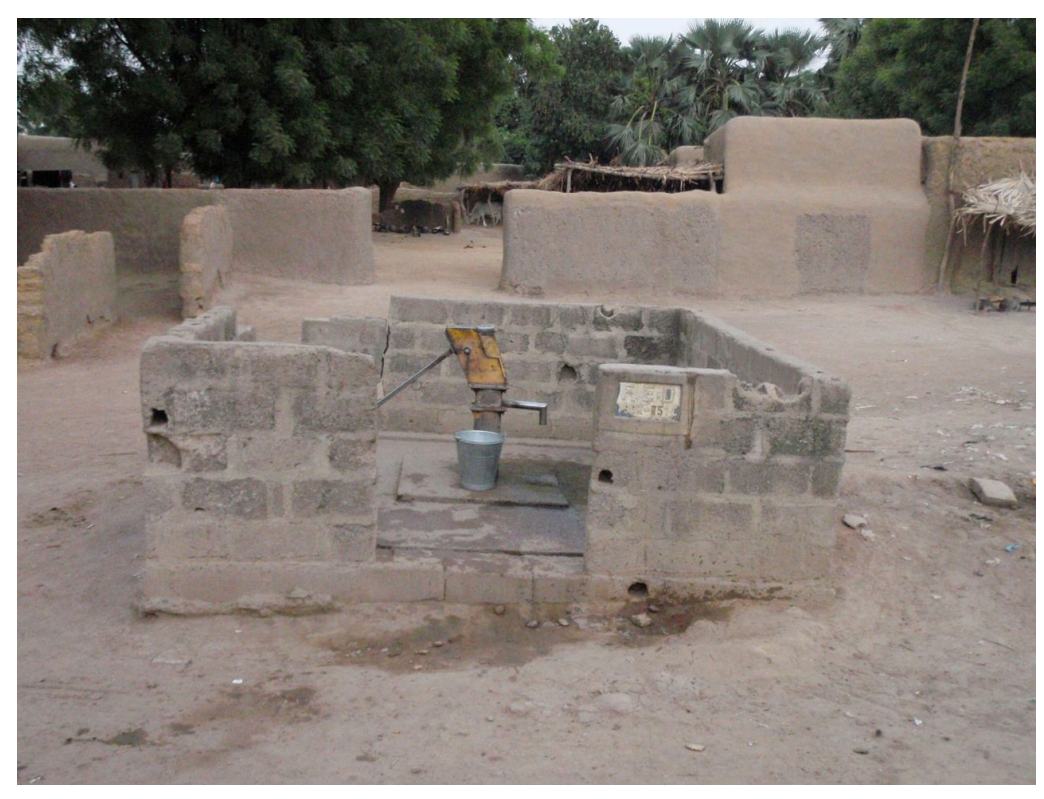

Figure A.6 Hand Pump P1

(This is the pump I used for my drinking water.) 


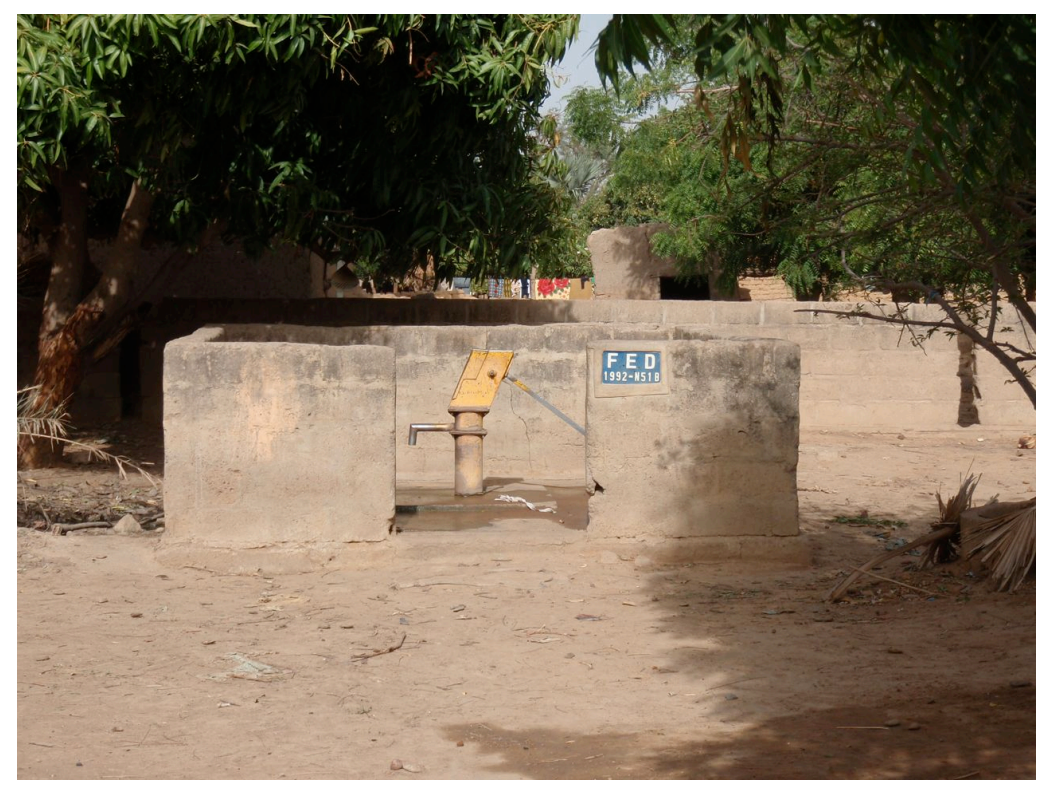

Figure A.7 Hand Pump P2

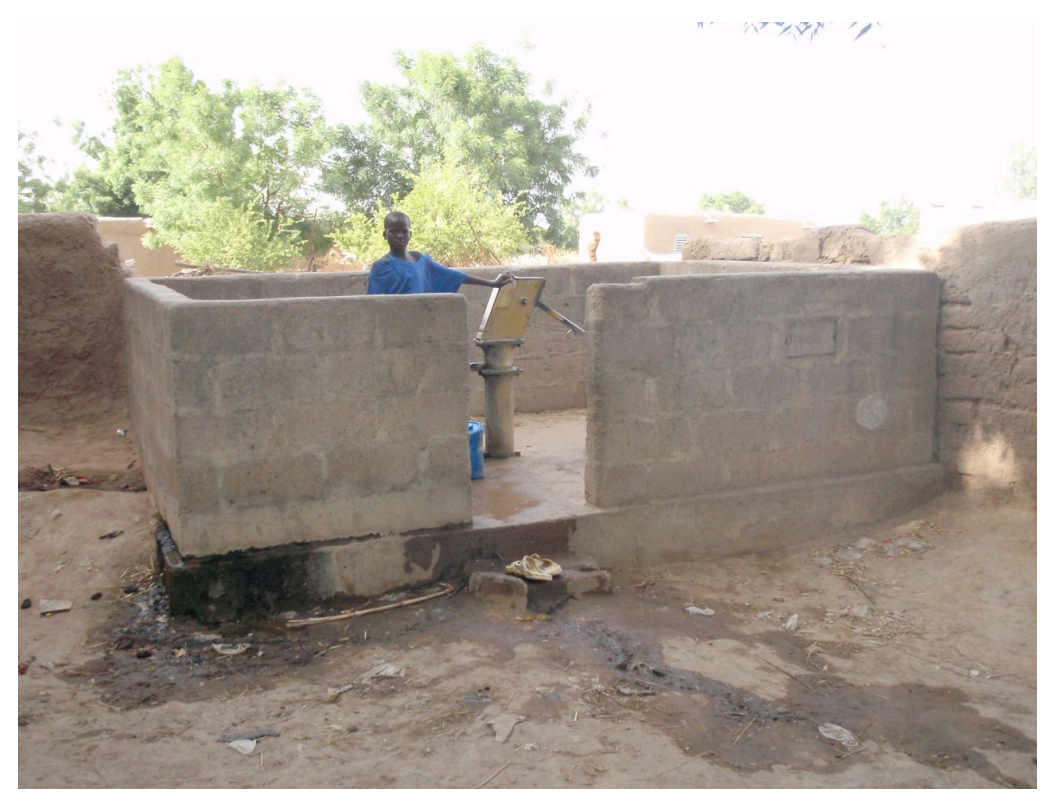

Figure A.9 Hand Pump P3 


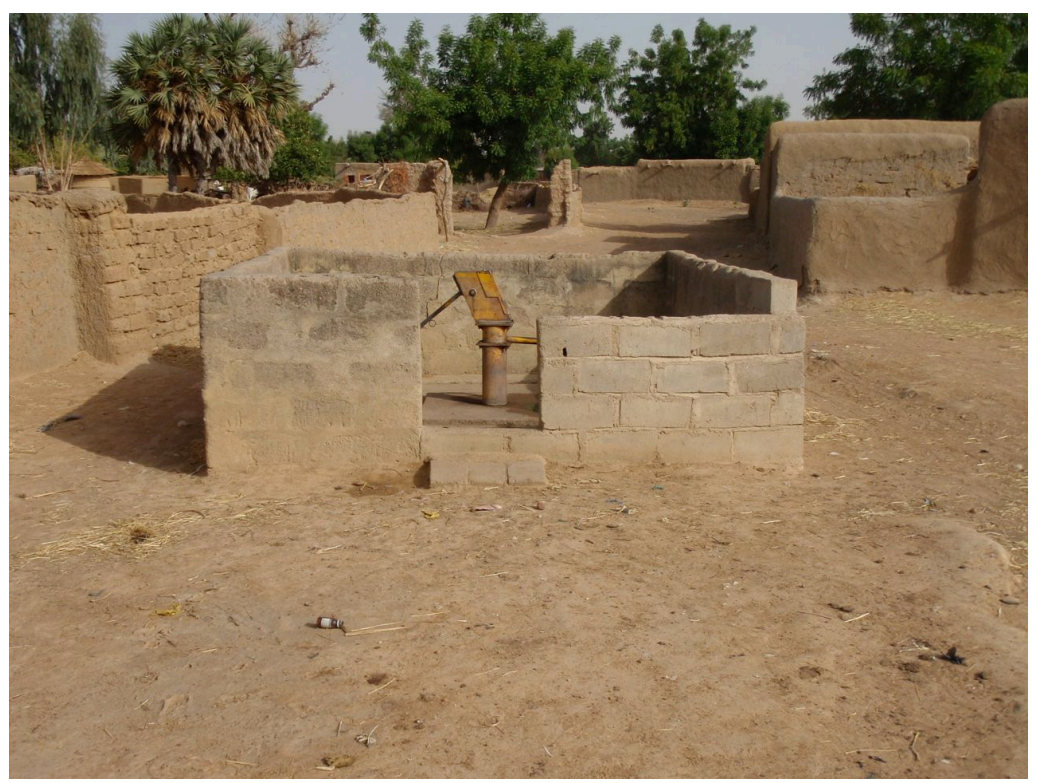

Figure A.9 Hand Pump P4 


\title{
APPENDIX B
}

\author{
Raw Data
}

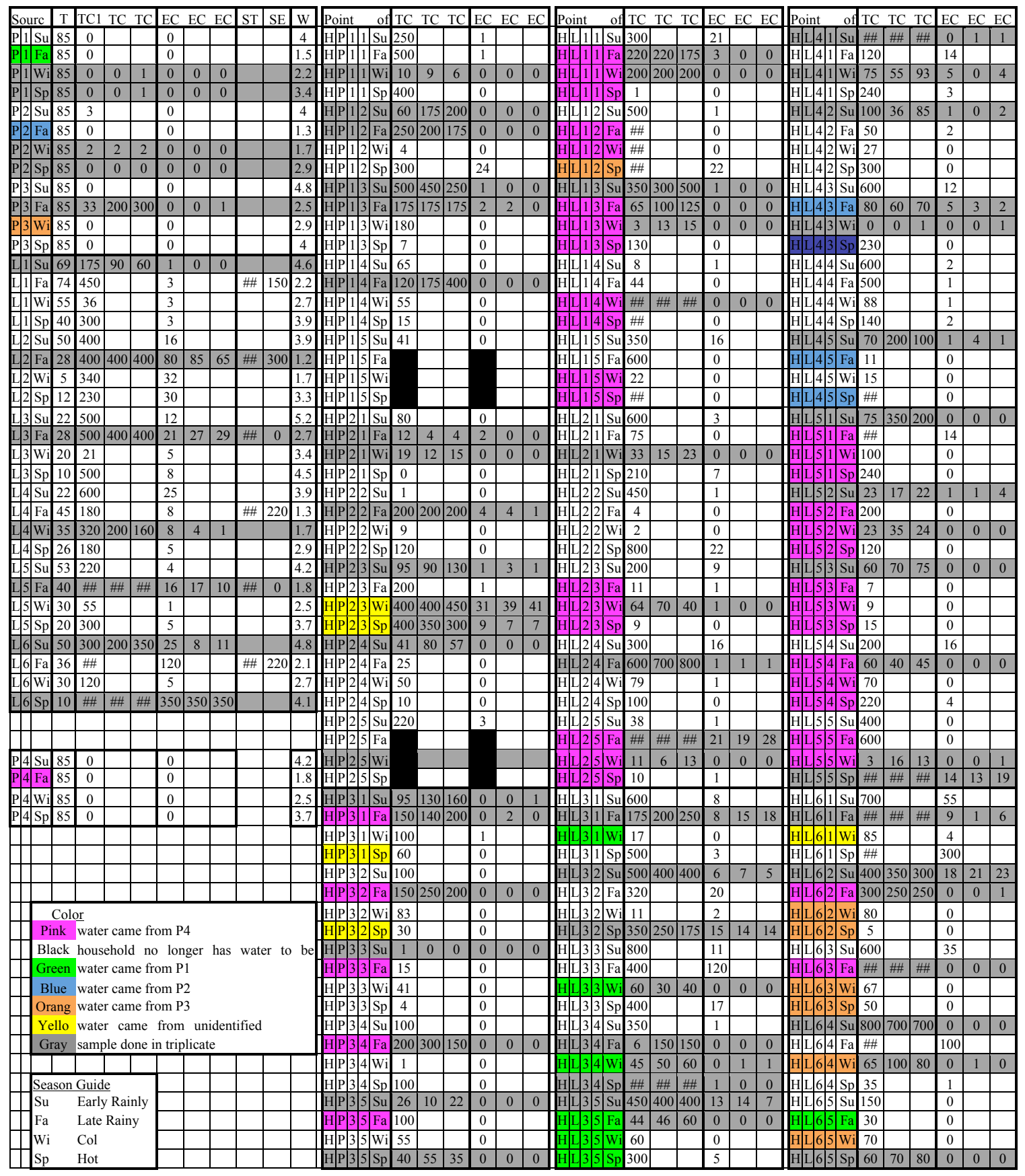




\section{APPENDIX C}

Data for Households Using Hand Pumps

\begin{tabular}{|c|c|c|c|c|c|c|c|}
\hline \multicolumn{2}{|c|}{ Early Rainy } & \multicolumn{2}{|c|}{ Late Rainy } & \multicolumn{2}{|l|}{ Cold } & \multicolumn{2}{|c|}{ Hot } \\
\hline TC & $\mathbf{E C}$ & TC & EC & TC & EC & TC & EC \\
\hline 20 & 1 & 500 & 1 & $10,9,6$ & $0,0,0$ & $\mathrm{TC}$ & $\overline{\mathrm{EC}}$ \\
\hline $60,175,200$ & $0,0,0$ & $250,200,175$ & $0,0,0$ & 4 & 0 & 400 & 0 \\
\hline $500,450,250$ & $1,0,0$ & $175,175,175$ & $2,2,0$ & 180 & 0 & 300 & 24 \\
\hline 65 & 0 & $120,175,400$ & $0,0,0$ & 55 & 0 & 7 & 0 \\
\hline 41 & 0 & $12,4,4$ & $2,0,0$ & $19,12,15$ & $0,0,0$ & 15 & 0 \\
\hline 80 & 0 & $200,200,200$ & $4,4,1$ & 9 & 0 & 0 & 0 \\
\hline 1 & 0 & 200 & 1 & 50 & 0 & 120 & 0 \\
\hline $95,90,130$ & $1,3,1$ & 25 & 0 & 100 & 2 & 10 & 0 \\
\hline $41,80,57$ & $0,0,0$ & $150,140,200$ & $0,2,0$ & 83 & 0 & 4 & 0 \\
\hline 220 & 3 & $150,250,200$ & $0,0,0$ & 41 & 0 & 100 & 0 \\
\hline $95,130,160$ & $0,0,1$ & 15 & 0 & 1 & 0 & \multicolumn{2}{|c|}{$40,55,350,0,0$} \\
\hline 100 & 0 & $200,300,150$ & $0,0,0$ & 55 & 0 & 1 & 0 \\
\hline $1,0,0$ & $0,0,0$ & 100 & 0 & $200,200,200$ & $0,0,0$ & 100 & 22 \\
\hline 100 & 0 & $220,220,175$ & $3,0,0$ & 1000 & 0 & 130 & 0 \\
\hline \multirow[t]{18}{*}{$26,10,22$} & $0,0,0$ & 1,000 & 0 & $3,13,15$ & $0,0,0$ & 1000 & 0 \\
\hline & & $65,100,125$ & $0,0,0$ & $1000,1000,100$ & $0,0,0$ & 1000 & 0 \\
\hline & & 11 & 1 & 22 & 0 & 9 & 0 \\
\hline & & $1000,1000,1000$ & $1,19,28$ & $64,70,40$ & $2,0,0$ & 10 & 1 \\
\hline & & $46,46,60$ & 0,0 & $11,6,13$ & $0,0,0$ & 300 & 5 \\
\hline & & $80,60,70$ & $5,3,2$ & 17 & 0 & 230 & 0 \\
\hline & & 11 & 0 & $60,30,40$ & $0,0,0$ & 1000 & 0 \\
\hline & & 1000 & 14 & $45,50,60$ & $0,2,2$ & 240 & 0 \\
\hline & & 200 & 0 & 60 & 0 & 120 & 0 \\
\hline & & 7 & 0 & 100 & 0 & 15 & 0 \\
\hline & & $60,40,45$ & $0,0,0$ & $23,35,24$ & $0,0,0$ & 220 & 4 \\
\hline & & 600 & 0 & 9 & 0 & 5 & 0 \\
\hline & & $300,250,250$ & $0,0,1$ & 70 & 0 & 50 & 0 \\
\hline & & $1000,1000,1000$ & $0,0,0$ & $3,16,13$ & $0,0,1$ & & \\
\hline & & 300 & 0 & 80 & 0 & & \\
\hline & & & & 67 & 0 & & \\
\hline & & & & $65,100,80$ & $0,1,0$ & & \\
\hline & & & & 70 & 0 & & \\
\hline
\end{tabular}


Data for Households Using Dug Wells

\begin{tabular}{|c|c|c|c|c|c|c|c|}
\hline \multicolumn{2}{|c|}{ Early Rainy } & \multicolumn{2}{|c|}{ Late Rainy } & \multicolumn{2}{|c|}{ Cold } & \multicolumn{2}{|l|}{ Hot } \\
\hline TC & EC & TC & EC & TC & EC & TC & EC \\
\hline 300 & 21 & 44 & 0 & $33,15,23$ & $0,0,0$ & 210 & 22 \\
\hline 500 & 1 & 600 & 0 & 2 & 0 & 800 & 0 \\
\hline $350,300,500$ & $1,0,0$ & 75 & 0 & 79 & 1 & 100 & 3 \\
\hline 8 & 1 & 4 & 0 & 11 & 2 & 500 & $15,14,1$ \\
\hline 350 & 16 & $600,700,80$ & $1,1,1$ & $75,55,93$ & $5,0,4$ & $350,250,175$ & 17 \\
\hline 600 & 3 & $175,200,25$ & $8,15,1$ & 27 & 0 & 400 & $1,0,0$ \\
\hline 450 & 1 & 320 & 20 & $0,0,1$ & $0,0,1$ & $1000,1000,100$ & 3 \\
\hline 200 & 9 & 400 & 120 & 88 & 1 & 240 & 0 \\
\hline 300 & 16 & $6,150,150$ & $0,0,0$ & 15 & 0 & 300 & 2 \\
\hline 38 & 1 & 120 & 14 & 85 & 4 & 140 & $14,13,1$ \\
\hline 600 & 8 & 50 & 2 & $400,400,45$ & $31,39,4$ & $1000,1000,100$ & 300 \\
\hline $500,400,400$ & $6,7,5$ & 500 & 1 & & & 1000 & 1 \\
\hline 800 & 11 & 1000 & 100 & & & 35 & $0,0,0$ \\
\hline 350 & 1 & & & & & $60,70,80$ & $9,7,7$ \\
\hline $450,400,400$ & $13,14,7$ & & & & & $400,350,300$ & 0 \\
\hline $1000,1000,100$ & $0,1,1$ & & & & & 60 & 0 \\
\hline $100,36,85$ & $1,0,2$ & & & & & 30 & \\
\hline 600 & 12 & & & & & & \\
\hline 600 & 2 & & & & & & \\
\hline $70,200,100$ & $1,4,1$ & & & & & & \\
\hline $75,350,300$ & $0,0,0$ & & & & & & \\
\hline $23,17,22$ & $1,1,4$ & & & & & & \\
\hline $60,70,75$ & $0,0,0$ & & & & & & \\
\hline 200 & 16 & & & & & & \\
\hline 400 & 0 & & & & & & \\
\hline 700 & 55 & & & & & & \\
\hline $400,350,300$ & $18,21,2$ & & & & & & \\
\hline 600 & 35 & & & & & & \\
\hline $800,700,700$ & $0,0,0$ & & & & & & \\
\hline
\end{tabular}




\title{
APPENDIX D
}

\author{
Sample calculations
}

\section{Analysis of Variance test (ANOVA)}

Parametric test to compare the means of several populations.

Assumes populations follow a normal distribution.

Can still be good approximation if populations do not follow normal distribution.

Source: Porkess, R. (2000). Collins Web-Linked Dictionary of Statistics. Glasgow, Harper Collins Publishers.

\section{Null Hypothesis}

Ho There is no difference in CFU counts in storage containers using hand pumps across seasons.

(Water in containers is the same across seasons.)

$\mathrm{Hl}$ There is a difference in CFU counts in storage containers using hand pumps across seasons. (Water in containers is different across seasons.)

\section{Originaldata set}

Results using EXCEL Data Analysis ToolPak

Dug Well Households

(total coliform CFU count $=<=150$ )

\begin{tabular}{|c|c|c|c|c|c|c|c|c|c|c|}
\hline $\begin{array}{l}\text { Early } \\
\text { Rainy }\end{array}$ & $\begin{array}{l}\text { Late } \\
\text { Rainy }\end{array}$ & Cold & Hot & SUMMARY & & & & & & \\
\hline 8 & 4 & 0 & 30 & Groups & Count & Sum & Average & Variance & & \\
\hline 17 & 6 & 0 & 35 & Column 1 & 15 & 929 & 61.933333 & 1496.06667 & & \\
\hline 22 & 44 & 1 & 60 & Column 2 & 8 & 599 & 74.875 & 3523.26786 & & \\
\hline 23 & 50 & 2 & 60 & Column 3 & 16 & 602 & 37.625 & 1252.11667 & & \\
\hline 36 & 75 & 11 & 70 & Column 4 & 8 & 575 & 71.875 & 1270.98214 & & \\
\hline 38 & 120 & 15 & 80 & & & & & & & \\
\hline 60 & 150 & 15 & 100 & & & & & & & \\
\hline 70 & 150 & 23 & 140 & ANOVA & & & & & & \\
\hline 70 & & 27 & & Source of Variation & $S S$ & $d f$ & $M S$ & $F$ & P-value & $F$ crit \\
\hline 75 & & 33 & & Between Groups & 10683.18 & 3 & 3561.0612 & 2.08941309 & 0.1156667 & 2.8216 \\
\hline 75 & & 55 & & Within Groups & 73286.43 & 43 & 1704.3357 & & & \\
\hline 85 & & 75 & & & & & & & & \\
\hline 100 & & 79 & & Total & 83969.62 & 46 & & & & \\
\hline 100 & & 85 & & & & & & & & \\
\hline 150 & & 88 & & Result: & same & & & & & \\
\hline
\end{tabular}

\section{Result interpretation}

If $\mathrm{F}<\mathrm{F}$ crit , accept null hypothesis. Result = samples are the same 


\section{Kruskal-Wallis test}

"Non parametric test that three or more samples are drawn from population"

Source: Porkess, R. (2000). Collins Web-Linked Dictionary of Statistics. Glasgow, Harper Collins Publishers.

\section{Null Hypothesis}

Ho There is no difference in CFU counts in storage containers using hand pumps across seasons (Water in containers is the same across seasons.)

$\mathrm{Hl}$ There is a difference in CFU counts in storage containers using hand pumps across seasons. (Water in containers is different across seasons.)

$5 \%$ level of significance

1 -tail te st

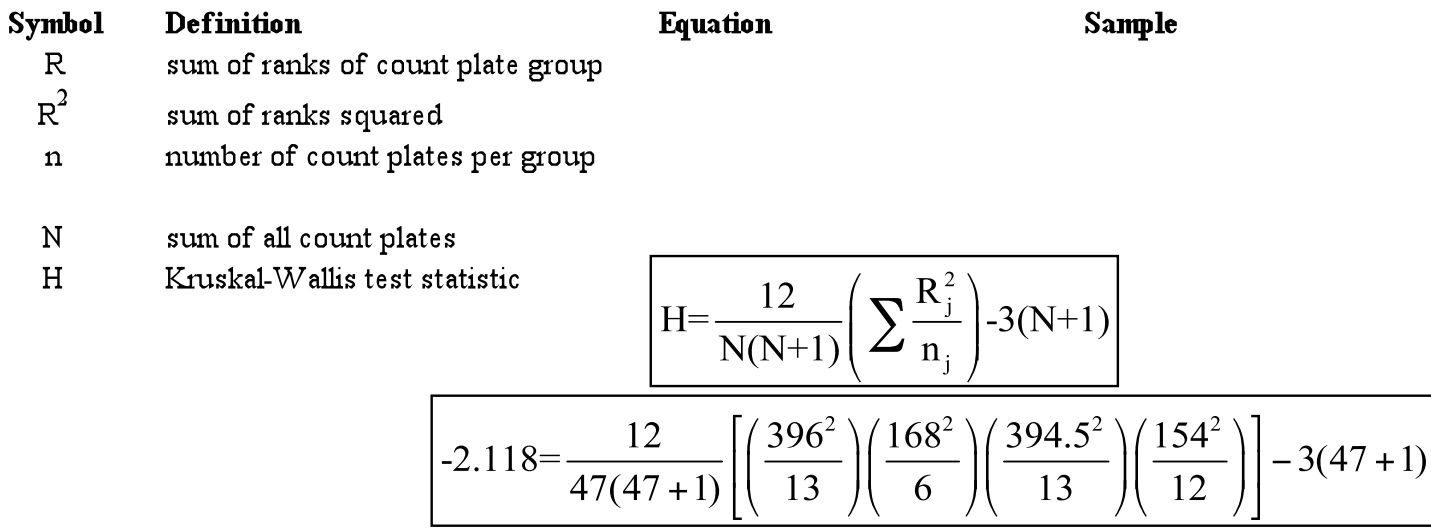

$\mathrm{K} \quad$ number of groups

Deg. of One less than number of groups $\quad$ Deg. of freedom=K-1 $3=4-1$ freedom

\section{Result interpretation}

If $\mathrm{H}<5 \%$ Chi Distribution Value, accept null hypothesis. Re sult = samples are the same. 


\begin{tabular}{|c|c|c|c|c|c|c|c|}
\hline \multicolumn{4}{|c|}{$\begin{array}{l}\text { Original ranked data set } \\
\text { (Dug Wells, } C F U \text { count }<=150 \text { ) }\end{array}$} & \multicolumn{4}{|c|}{ Ranked data categorized by season } \\
\hline \multirow{2}{*}{\multicolumn{4}{|c|}{$\begin{array}{l}\text { (Households) } \\
\text { E.coli E.coli }\end{array}$}} & & & & \\
\hline & & & & $\begin{array}{l}\text { Early } \\
\text { Rainy }\end{array}$ & $\begin{array}{l}\text { Late } \\
\text { Rainy }\end{array}$ & Cold & Hot \\
\hline$\overline{\overline{F A}}$ & $\overline{0}$ & $\overline{13.5}$ & & 13.5 & 13.5 & 13.5 & 13.5 \\
\hline FA & 0 & 13.5 & & 13.5 & 13.5 & 13.5 & 13.5 \\
\hline FA & 0 & 13.5 & & 13.5 & 13.5 & 13.5 & 13.5 \\
\hline FA & 0 & 13.5 & & 13.5 & 13.5 & 13.5 & 13.5 \\
\hline FA & 0 & 13.5 & & 13.5 & 13.5 & 13.5 & 13.5 \\
\hline FA & 0 & 13.5 & & 13.5 & 13.5 & 13.5 & 13.5 \\
\hline FA & 2 & 40 & & 33 & 40 & 13.5 & 33 \\
\hline FA & 14 & 47 & & 33 & 47 & 13.5 & 40 \\
\hline $\mathrm{SP}$ & 0 & 13.5 & & 33 & & 13.5 & \\
\hline SP & 0 & 13.5 & & 33 & & 33 & \\
\hline $\mathrm{SP}$ & 0 & 13.5 & & 33 & & 33 & \\
\hline SP & 0 & 13.5 & & 33 & & 33 & \\
\hline SP & 0 & 13.5 & & 33 & & 40 & \\
\hline SP & 0 & 13.5 & & 40 & & 44 & \\
\hline SP & 1 & 33 & & 44 & & 44 & \\
\hline SP & 2 & 40 & & & & 46 & \\
\hline SU & 0 & 13.5 & & & & & \\
\hline SU & 0 & 13.5 & & & & & \\
\hline SU & 0 & 13.5 & $\mathrm{R}$ & 396 & 168 & 394.5 & 154 \\
\hline SU & 0 & 13.5 & $\mathrm{R}^{2}$ & 156816 & 28224 & 155630.25 & 23716 \\
\hline SU & 0 & 13.5 & $\mathrm{n}$ & 15 & 8 & 16 & 8 \\
\hline SU & 0 & 13.5 & & & & & \\
\hline SU & 1 & 33 & & & $5 \% \mathrm{C}$ & ii Distributic & Value \\
\hline SU & 1 & 33 & $\mathrm{~N}$ & 47 & & (from a tabl & \\
\hline SU & 1 & 33 & $\mathrm{H}$ & -2.118 & & 7.815 & \\
\hline SU & 1 & 33 & $\mathrm{~K}$ & 4 & & & \\
\hline SU & 1 & 33 & Deg. of & 3 & & Result: & same \\
\hline SU & 1 & 33 & freedom & & & & \\
\hline SU & 1 & 33 & & & & & \\
\hline SU & 2 & 40 & & & & & \\
\hline SU & 4 & 44 & & & & & \\
\hline WI & 0 & 13.5 & & & & & \\
\hline WI & 0 & 13.5 & & & & & \\
\hline WI & 0 & 13.5 & & & & & \\
\hline WI & 0 & 13.5 & & & & & \\
\hline WI & 0 & 13.5 & & & & & \\
\hline WI & 0 & 13.5 & & & & & \\
\hline WI & 0 & 13.5 & & & & & \\
\hline WI & 0 & 13.5 & & & & & \\
\hline WI & 0 & 13.5 & & & & & \\
\hline WI & 1 & 33 & & & & & \\
\hline WI & 1 & 33 & & & & & \\
\hline WI & 1 & 33 & & & & & \\
\hline WI & 2 & 40 & & & & & \\
\hline WI & 4 & 44 & & & & & \\
\hline WI & 4 & 44 & & & & & \\
\hline WI & 5 & 46 & & & & & \\
\hline
\end{tabular}




\section{Mann Whitney test}

"Non parametric test that two samples are drawn from populations with the same distribution"

Source: Porkess, R. (2000). Collins Web-Linked Dictionary of Statistics. Glasgow, Harper Collins Publishers.

\section{Null Hypothesis}

Ho There is no difference in CFU counts in storage containers according to source. (Water in containers is the same.)

$\mathrm{Hl} \quad$ There is a difference in CFU counts in storage containers according to source. (Water in containers is different.)

$5 \%$ level of significance

2-tail test

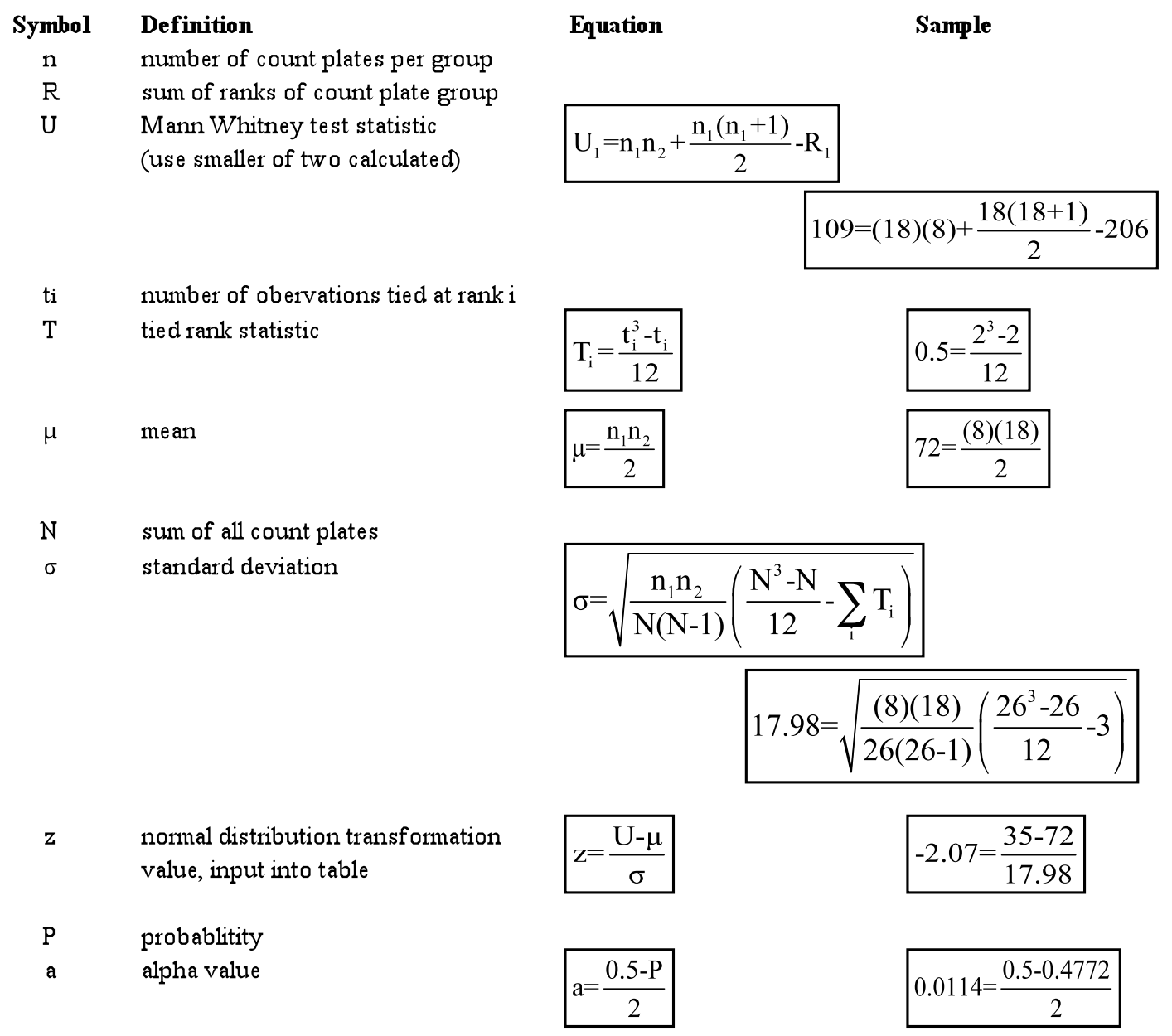

\section{Result interpretation}

If $a<.05$, reject null hypothesis. Result = samples are different . 


\begin{tabular}{|c|c|c|c|c|c|c|c|c|}
\hline \multicolumn{4}{|c|}{ Original ranked data set (all) } & \multirow{2}{*}{\multicolumn{2}{|c|}{$\begin{array}{l}\text { Dug Well } \\
\text { Households }\end{array}$}} & & \multirow{2}{*}{\multicolumn{2}{|c|}{$\begin{array}{l}\text { Hand PumP } \\
\text { Households }\end{array}$}} \\
\hline \multirow{2}{*}{$\begin{array}{l}\text { Hot Season } \\
\text { Point of Use }\end{array}$} & \multirow{2}{*}{$\begin{array}{c}\text { E.coli } \\
\text { Average }\end{array}$} & \multirow{2}{*}{$\begin{array}{l}\text { E.coli } \\
\text { Rank }\end{array}$} & \multirow{2}{*}{$\begin{array}{c}\text { E.coli } \\
\text { ti }\end{array}$} & & & & & \\
\hline & & & & \multicolumn{2}{|c|}{ E.coli Ranks } & & \multicolumn{2}{|c|}{ E.coli Ranks } \\
\hline $\begin{array}{l}P \text { SP } \\
\text { P }\end{array}$ & 0 & 1 & & 11 & & & & 1 \\
\hline $\mathrm{P}$ SP & 1 & 2 & & 13 & & & & 2 \\
\hline P SP & 4 & 3 & & 18 & & & & 3 \\
\hline $\mathrm{P} \mathrm{SP}$ & 5 & 4 & & 18 & & & & 4 \\
\hline P SP & 7 & 5 & & 19 & & & & 5 \\
\hline P SP & 9 & 6 & & 20 & & & & 6 \\
\hline P SP & 10 & 7.5 & & 22 & & & & 7.5 \\
\hline P SP & 10 & 7.5 & 2 & 26 & & & & 7.5 \\
\hline P SP & 15 & 9.5 & & & & & & 9.5 \\
\hline P SP & 15 & 9.5 & 2 & & & & & 9.5 \\
\hline W SP & 30 & 11 & & & & & & 12.5 \\
\hline $\mathrm{P}$ SP & 35 & 12.5 & & & & & & 14 \\
\hline W SP & 35 & 12.5 & 2 & & & & & 15 \\
\hline P SP & 40 & 14 & & & & & & 16 \\
\hline $\mathrm{P} \mathrm{SP}$ & 50 & 15 & & & & & & 21.5 \\
\hline P SP & 55 & 16 & & & & & & 23.5 \\
\hline W SP & 60 & 17.8 & & & & & & 23.5 \\
\hline W SP & 60 & 17.5 & 2 & & & & & 25 \\
\hline W SP & 70 & 19 & & & & & & \\
\hline W SP & 80 & 20 & & & & & & \\
\hline P SP & 100 & 21.5 & & & & & & \\
\hline W SP & 100 & 21.5 & 2 & & & & & \\
\hline P SP & 120 & 23.5 & & $\mathrm{n}$ & & & $\mathrm{n}$ & 18 \\
\hline P SP & 120 & 23.5 & 2 & $\mathrm{R} 1$ & & & $\mathrm{R}$ & 206 \\
\hline P SP & 130 & 25 & & $\mathrm{U}$ & & & $\mathrm{U}$ & 109 \\
\hline \multirow[t]{9}{*}{ W SP } & 140 & 26 & & & & & & \\
\hline & & & & E.coli & E.coli & $\mu$ & & 72 \\
\hline & & & & $\mathrm{ti}$ & $\mathrm{T}$ & Sum $\mathrm{T}$ & & 3 \\
\hline & & & & 2 & 0.5 & $\mathrm{~N}$ & & 26 \\
\hline & & & & 2 & 0.5 & $\sigma$ & & 17.98 \\
\hline & & & & 2 & 0.5 & z & & -2.07 \\
\hline & & & & 2 & 0.5 & $\mathrm{P}$ & & 0.477 \\
\hline & & & & 2 & 0.5 & $\mathrm{a}$ & & 0.0114 \\
\hline & & & & 2 & 0.5 & result & & different \\
\hline
\end{tabular}




\title{
APPENDIX E
}

\author{
Image Use Permissions
}

Figure 2.1 Location of Koila Bamana in Mali

Email communication on Wed, Jul 20, 2011 at 12:36 PM

From: Tom Pitman tom@wordtravels.com

To: Matt Seib matt.seib@gmail.com

Subject: RE: Wordtravels.com - Contact

Hi Matt

No problem, however please credit, and if online, please link to the source page.

Thanks, Tom

Figure 2.2 Diagram of the India Mark II hand pump

Email communication on Thu, Jul 7, 2011 at 11:20 AM

From: Sharad Jhunjhunwala jhunjhunwala.sharad@gmail.com

To: Matt Seib matt.seib@gmail.com

Subject: Re: India Mark II graphic use

Yes, You may use the file.

Regards

Sharad

Figure 2.5 List of improved and unimproved drinking water sources according to the Joint Monitoring Programme

As stated on the website http:/www.who.int/about/licensing/extracts/en/index.html:

If you wish to use the extract for research, private study or in a noncommercial document with limited circulation (such as an academic thesis or dissertation), you may do so without seeking permission. Our only requirement is that the WHO source should be appropriately acknowledged. 
Figures 2.6 Koila Bamana average monthly max and min temperatures and average monthly rainfall days

Figure 5.1 Relationship of seasonal variation in percent of hand pump and dug well households with plate count $>150$ compared to regional annual average temperature and rainfall days.

As stated on the website http://worldweather.wmo.int/note.htm:

The media are welcome to make available information on this web site to the public.

\section{For Figures 2.7 3.1, 4.14, 4.15, 4.16, 4.17:}

Figure 2.7 Location of Koila Bamana relative to Niger River, irrigated rice fields, and the major canal network for the area.

Figure 3.1 Water sources ( $\mathrm{W}=$ dug well, $\mathrm{P}=$ hand pump) plus households (circular and triangular markers) monitored during this study.

Figure 4.14 Early rainy season water collection

Figure 4.15 Late rainy season water collection

Figure 4.16 Cold season water collection

Figure 4.17 Hot season water collection

As stated on the website http://maps.google.com/support/bin/static.py?page=ts.cs\&ts=1342531:

All uses of Google Maps and Google Earth and its Content must provide attribution to Google and our suppliers. Google does not approve of any use of Content without proper attribution. Depending on the region, the Content provider may be Google alone or Google and one or more 3rd party providers.

\section{Requirements:}

Attribute Google (e.g. (C) 2011 Google) and third-party suppliers (e.g. (C) 2011 Tele Atlas) Make attribution readable to the average reader or viewer (e.g. avoid micro-sized letters) For Print: Display attribution within or immediately adjacent to the visual

For Online: Attribution is automatically added within the API and cannot not obscured. 


\section{For Figures 5.2 and 5.3:}

Figure 5.2 Intervention flow chart

Figure 5.3 Historical effectiveness of various interventions to prevent diarrhea

\section{From Copyright Clearance Center}

This is a License Agreement between Matthew D Seib ("You") and Elsevier ("Elsevier"). The license consists of your order details, the terms and conditions provided by Elsevier, and the payment terms and conditions.

License Number

License date

Licensed content publisher

Licensed content publication
2703671364293

Jul 07, 2011

Elsevier

The Lancet Infectious Diseases

Licensed content title Water, sanitation, and hygiene interventions to reduce diarrhoea in less developed countries: a systematic review and meta-analysis

Licensed content author Lorna Fewtrell, Rachel B Kaufmann, David Kay, Wayne Enanoria, Laurence Haller, John M Colford Jr

Licensed content date January 2005

Licensed content volume number 5

Licensed content issue number $\quad 1$

Number of pages $\quad 11$

Type of Use reuse in a thesis/dissertation

Portion figures/tables/illustrations

Number of figures/tables/illustrations $\quad 2$

Format electronic

Are you the author of this Elsevier article? No

Will you be translating? No

Order reference number $\quad 2703671364293$ 